\title{
URANIUM INVESTIGATIONS IN SOUTHEASTERN ALASKA
}

By

Gilbert R. Eakins

GEOLOGIC RLPOR'T 44

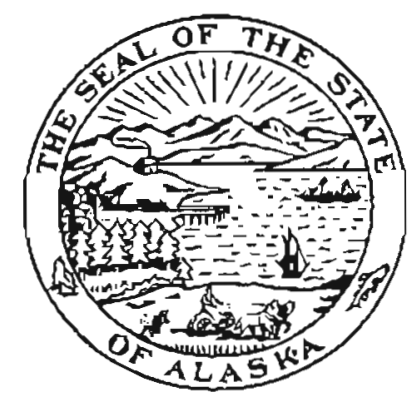

Pullished by

DIVISION OF GEOLOGICAL \& GEOPHYSICAL SUAVEYS

COLLEGE, ALASXA

1975 


\section{CONTENTS}

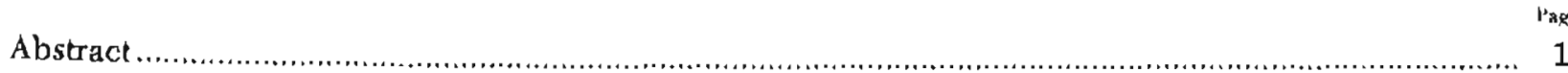

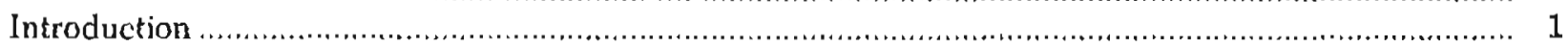

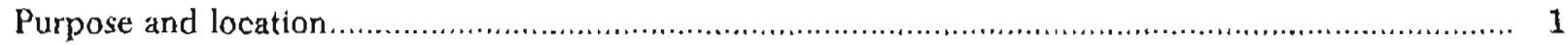

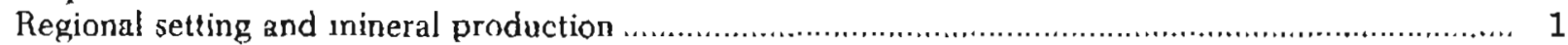

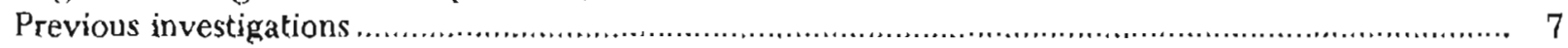

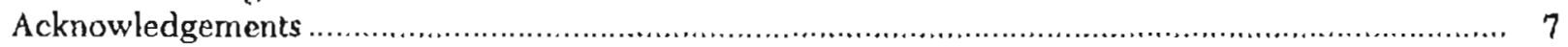

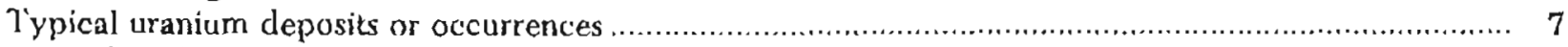

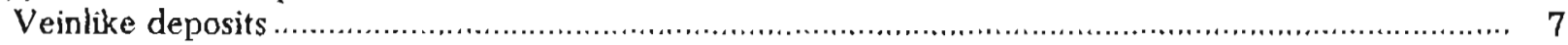

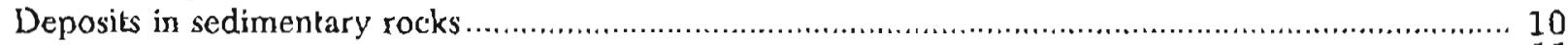

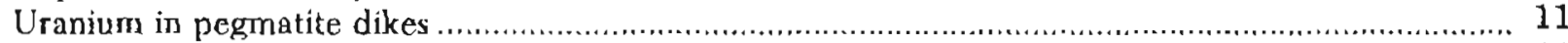

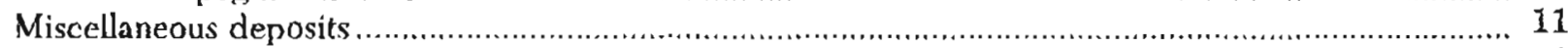

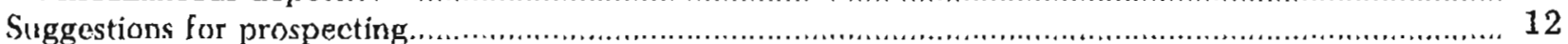

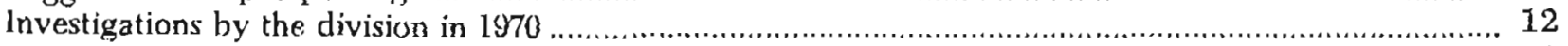

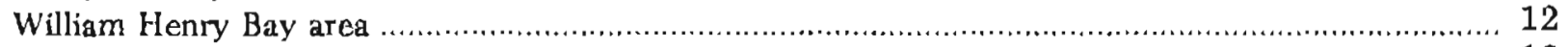

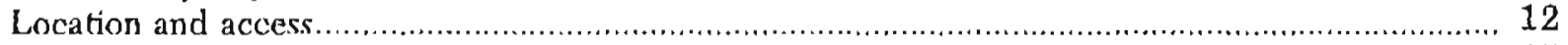

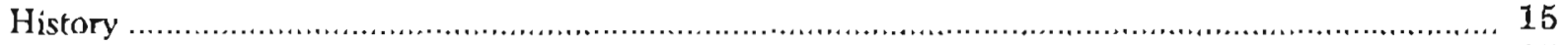

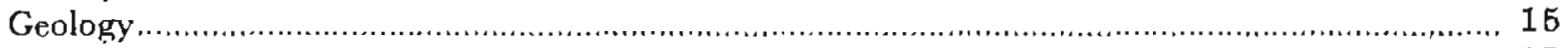

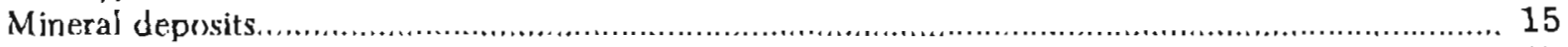

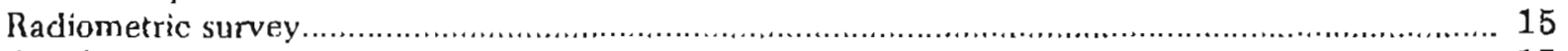

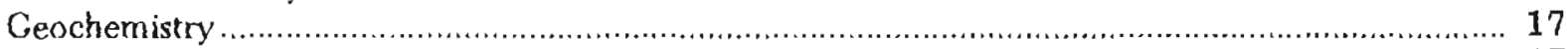

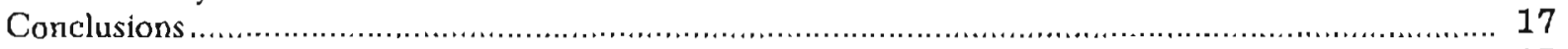

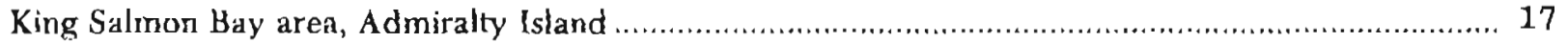

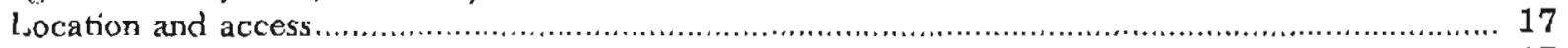

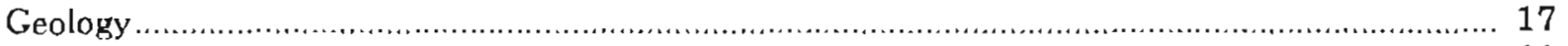

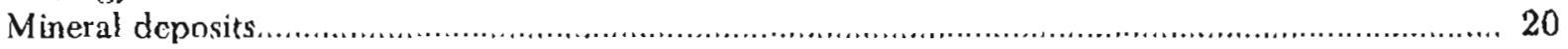

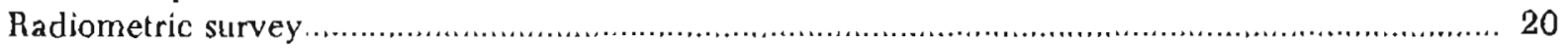

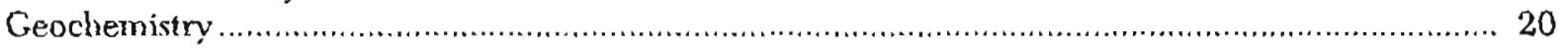

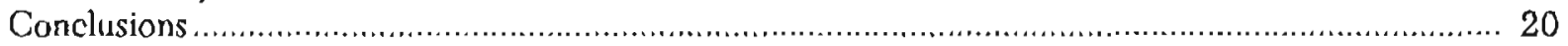

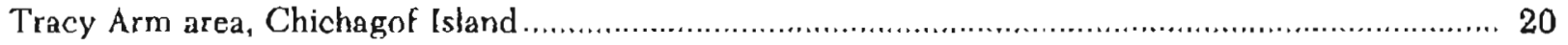

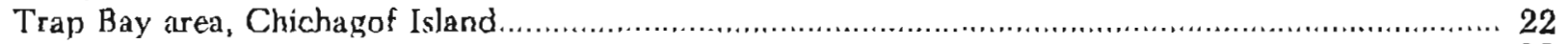

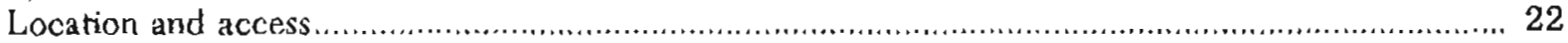

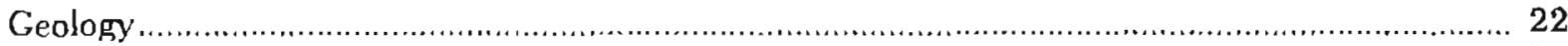

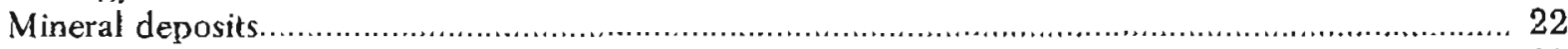

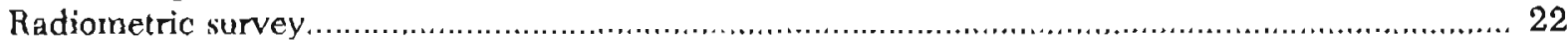

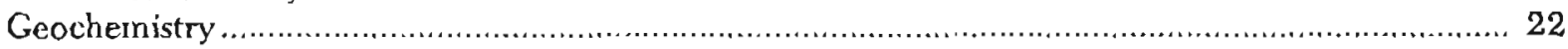

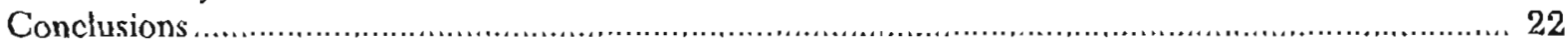

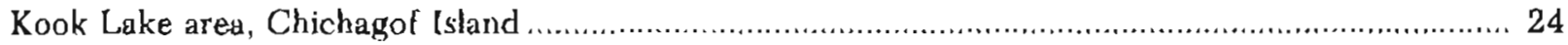

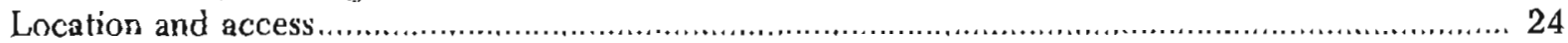

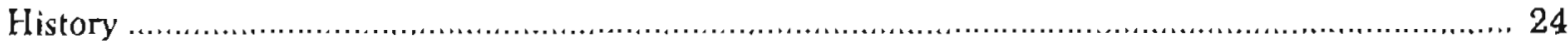

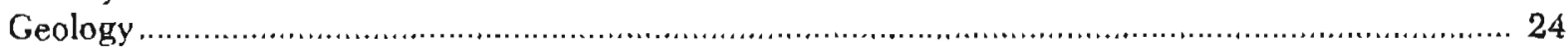

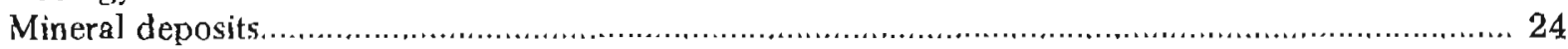

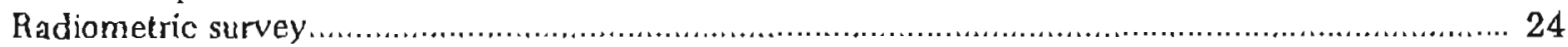

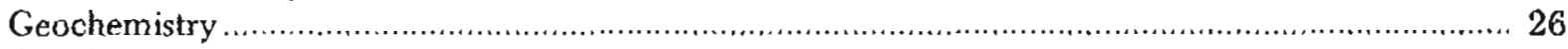

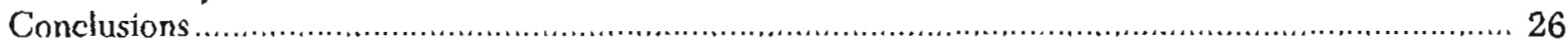

III 


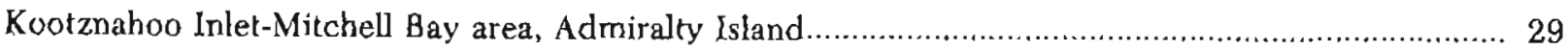

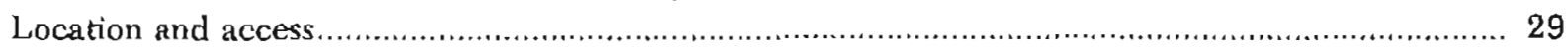

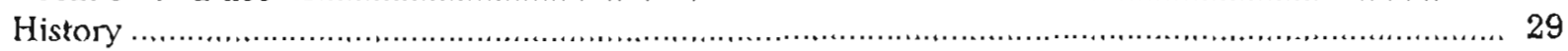

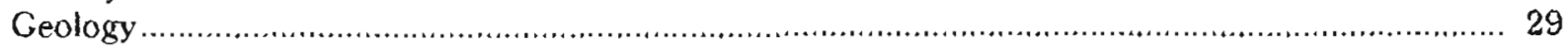

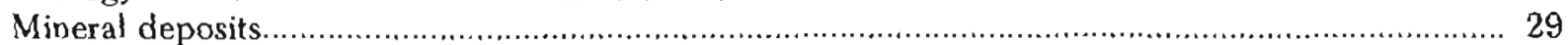

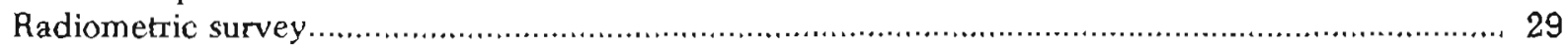

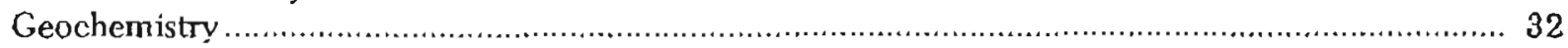

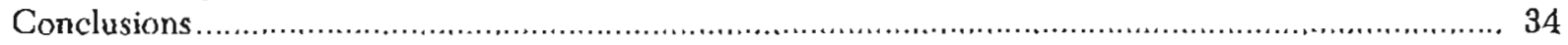

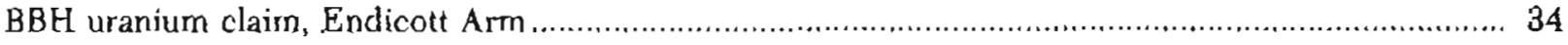

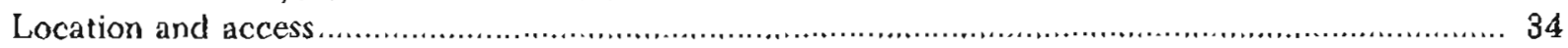

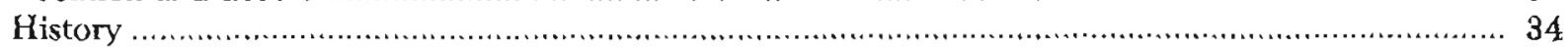

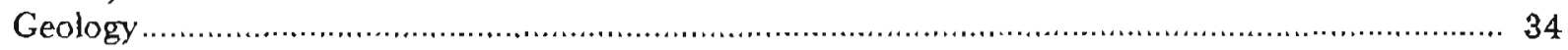

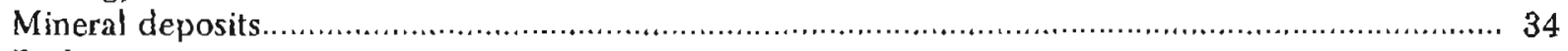

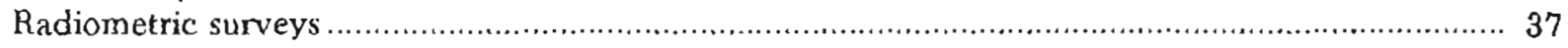

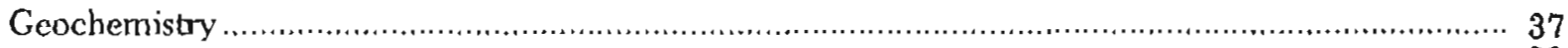

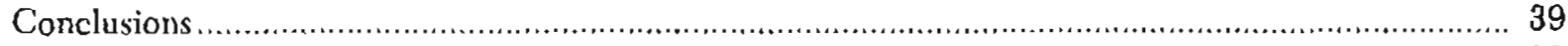

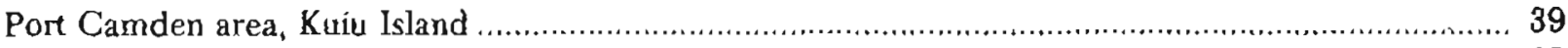

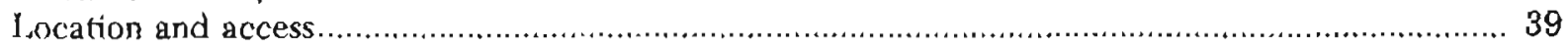

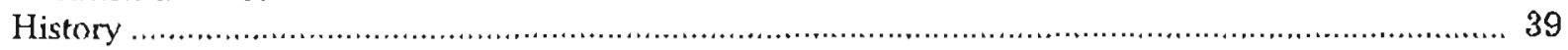

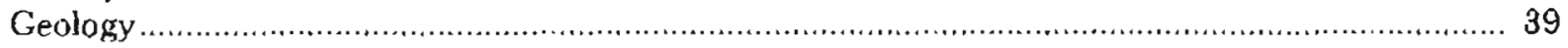

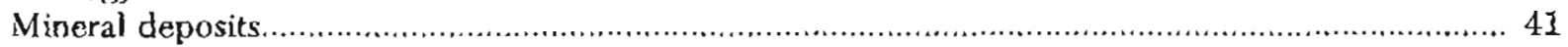

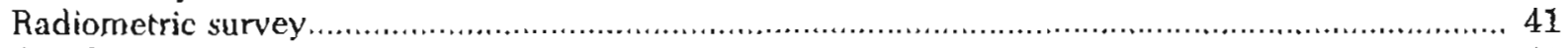

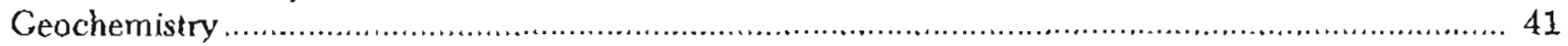

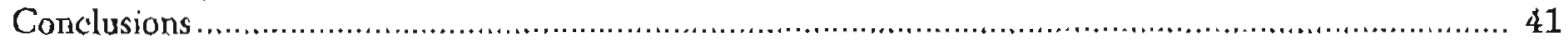

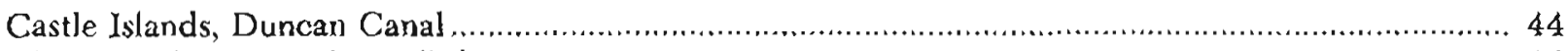

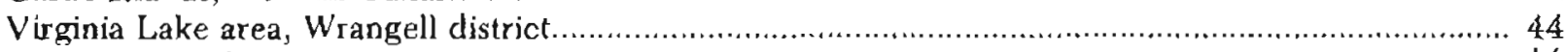

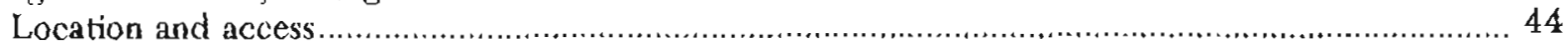

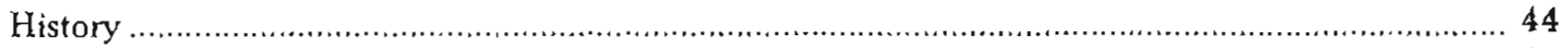

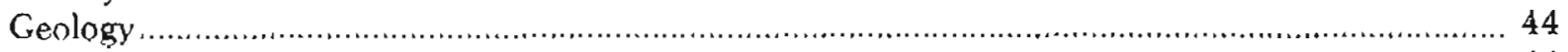

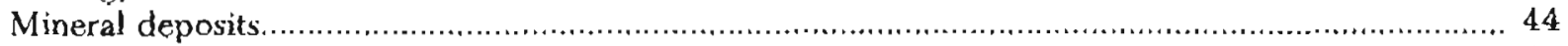

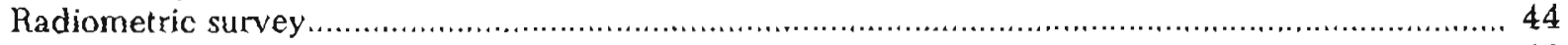

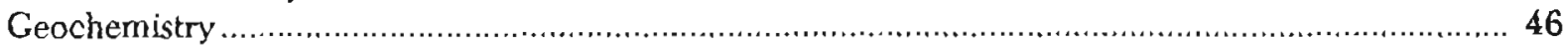

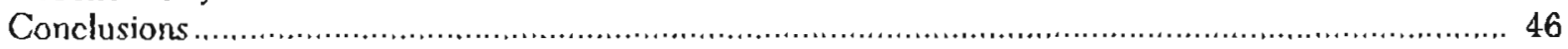

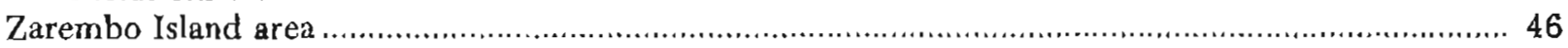

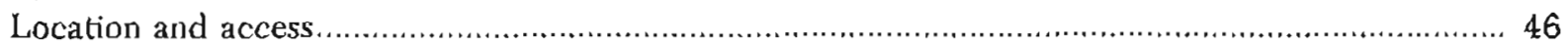

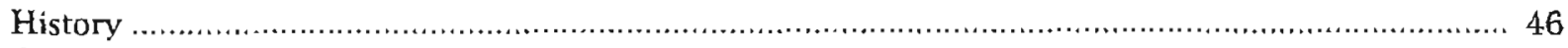

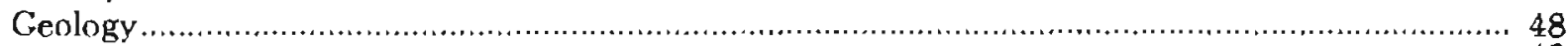

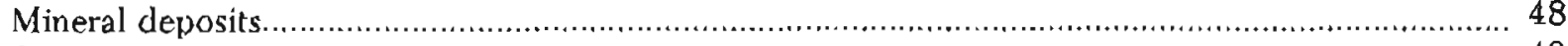

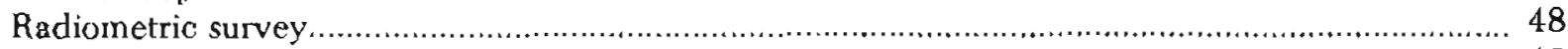

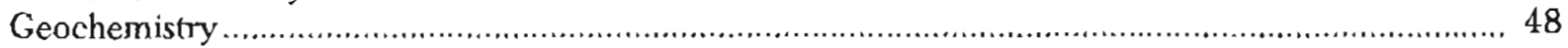

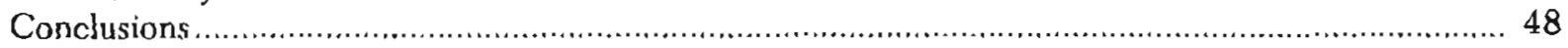

Salmon Bay area, Prince of Wales Island .......................................................................... 50

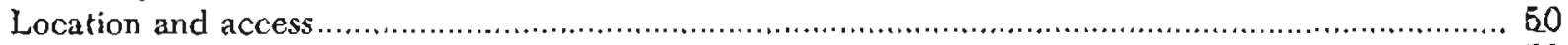

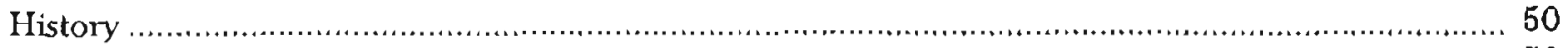

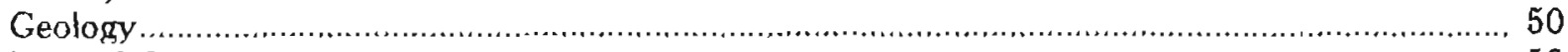

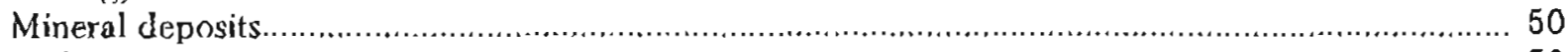

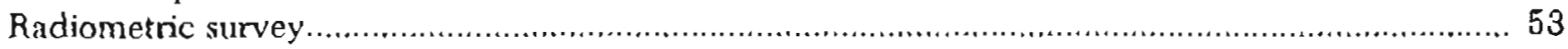

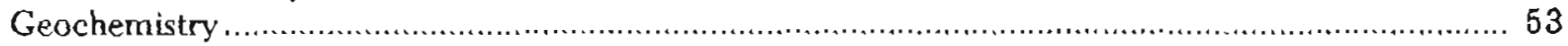

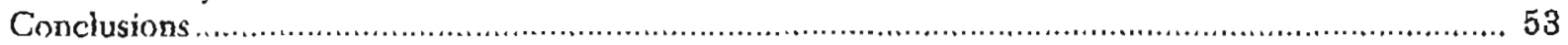

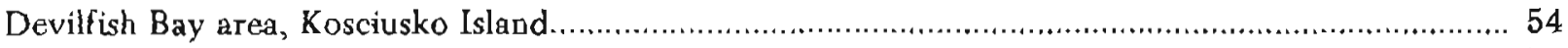

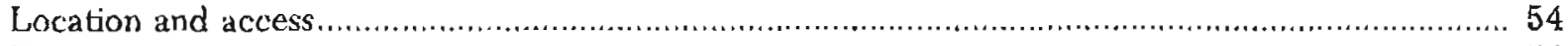

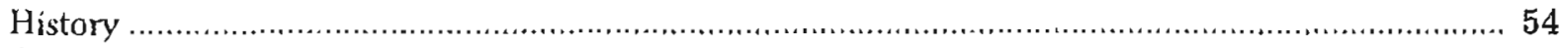

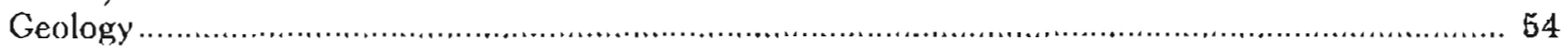


Mineral deposits

Radiometric survey

Geochemistry

Conclusions

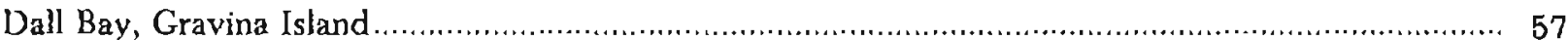

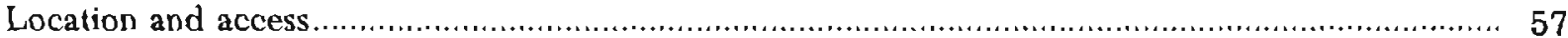

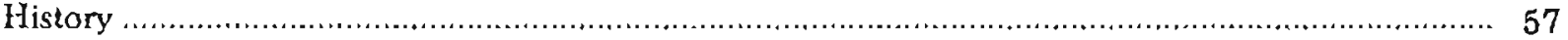

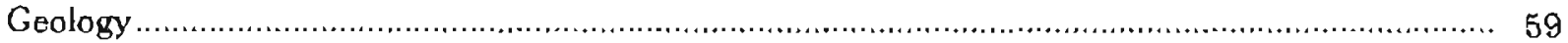

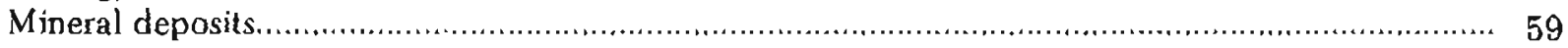

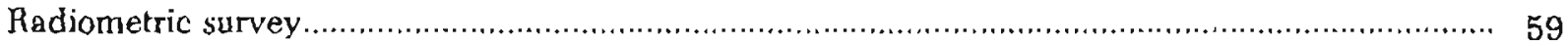

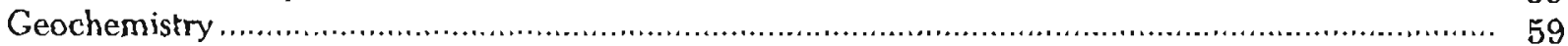

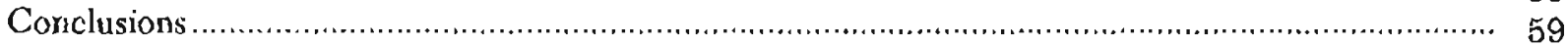

References

\section{ILLUSTRATIONS}

Ficure 1 Localities examined for radioactivity in 1970, Southeastern Alaska,

2 Distribution of certain metallic deposits and locations of known radioactive deposits, Southeastern Alaska....

3 Acid and intermediate intrusive rocks, Southeastem Alaska

4 Locations of veins, intrusive rocks, radiometric readings, and Lucky Six claim group, William Henry Bay area.......................................... 14

5 Radiometric survey on Lucky Six No. I claim .........................................................

6 Locations of geochemical samples and intrusive rocks,

William Henry Bay area

7 Frequency distribution histogram based on atomic absorption analyses

for copper, Jead, and zinc, William Henry Bay area

8 Locations of granite intrusive and stream-sediment samples,

King Salmon Bay area, Admiralty Island.

9 Geology, radiometric survey and stream-sediment sample locations,

Trap Bay area, Chichagof Island

10 Generalized geologic map, Kook Lake area, Southeastern Alaska

11 Stream-sediment sample locations, Kook Lake area, Chichagof Island.

12 Frequency distribution histogram based on atomic absorption analyses

for copper, lead, and zinc, Kook Lake area.....

13 Geologic and geochemical sample location map, Kootznahoo Inlet .

Mitchell Bay area..... 
Frgure 14 Tertiary sandstone with lenses of conglomerate, Kootznahoo Formation, Paqe

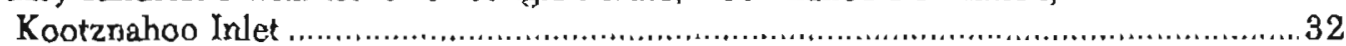

15 Frequency distribution histogram based on atomic absosorption analyses for copper, lead, and zinc, Kootznahoo Inlet-Mitchell Bay area ........................ 33

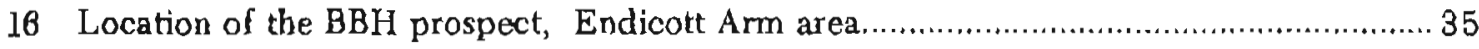

17 Reconnaissance geologic and stream-sediment sample locations, part of Endicott Arm area, Sumdum quadrangle..................................................... 36

18 BBH claim on the lower part of a stream course, Endicott Arm .............................. 37

19 Geologic sketch map of the BBH claim Endicott Arm area, Sumdum quadrangle...........38

20 Pegmatite lens in diorite near terminus of North Dawes Glacier,

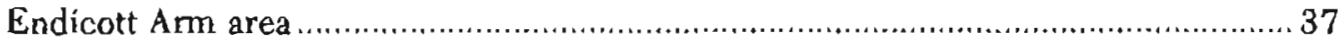

21 Reconnaissance geologic map and radiometric data, Port Camden area.......................40

22 Locations of stream-sediment samples and prospects, part of the Port Camden area.

23 Frequency distribution histogram based on atomic absorption analyses for

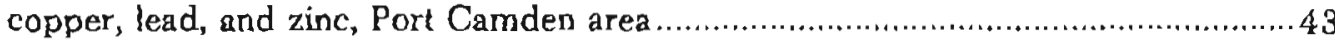

24 Reconnaissance geologic map and radiometric data, Virginia Lake area .....................45

25 Locations of stream-sediment samples, Virginia Lake area $\ldots \ldots \ldots \ldots \ldots \ldots \ldots \ldots \ldots \ldots \ldots \ldots \ldots \ldots . \ldots \ldots$

26 Frequency distribution histograms based on atomic absorption analyses for copper, lead, and zinc, Virginia Lake area......................................... 47

27 Geologic sketch map and stream-sediment sample locations, southwest coast of Zarembo Island

28 Geologic sketch map and radiometric data, Salmon Bay area, Prince of Wales Island.

29 Geologic sketch map, shore near Salmon Bay, Prince of Wales Island ..........................52

30 Radioactive carbonate vein cutting argillite, Salmon Bay area .................................53

31 Locations of stream-sediment samples, prospects, and part of the Dry Pass

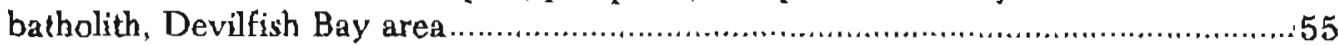

32 Geologic sketch map, prospect pit, Devilfish Bay ........................................66

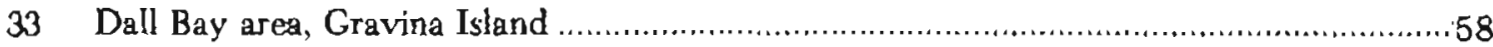




\section{TABLES}

$\begin{array}{ccc}\text { TABLE } & 1 & \text { Areas in Southeastem Alaska with significant radioactivity } \ldots \ldots \ldots \ldots \ldots \ldots \\ 2 & \text { Atomic absorption analyses, William Henry Bay area } \ldots \ldots \ldots \ldots \ldots \ldots\end{array}$




\title{
URANIUM INVESTIGATIONS IN SOUTHEASTERN ALASKA
}

\author{
by Gilbert R. Eakins
}

\begin{abstract}
ABSTHACT
Radioactive mincral deposits at 14 Incalities in Sombenstern Alaska are discussed to assist in the exploration for urasium). 'These areas, visited during the 1970 tield senson, were' selecled because of known or reported radioactivity and (or) favorable keology. Vein eleposits and nonmarine' 'Vertiary sandstonen were examined. Radionetric surveys were made on font, and small areas were mapped to slow the spatial relationship helween radioactivity and certain ore deposits.

Previousty unreported low radicsictive anomnalies were tound at several localitics, bue nome of the deposits was irflicated to be of comenercial grade. Slightly radioactive sandstone's were found at Port Contelen and on the west side of " harcmbe lwand. Radionctive pegenitiles al lindicolt Arm and clsewhere in Sontheastem Alaska de not appear to have cominercial prossibilines, but unay serve ns guides to mineralisution.

Cienclsemical stream-sediment smmples were collected int most of the lirealiliex exanibrel. A total nf 205 simulics were taken. Resilts of atomic ibsorption inalyses ure given lor copper, lead und rinc. strong geochemical unmmalies were" lound at Willium Henry Bay and Knok lake.

The best guides for oranitm exploration in Somtheastry Alaska are woda-rich granite and the ores and gangue miserals frequently associaled with uranium. 'I"hese inchuxle minerals containing copper, silver, cobath and inolybrienum, and hematite and fluosite. There is soruc incliention that musual amounts of uranium uninerals are present ius zones peripheral to inajor coppes districts.
\end{abstract}

\section{INTRODUCTION}

\section{PURPOSE AND LOCATION}

A strong demand for uranium to meet a critical energy shortage in the industrial nations is anticipated for the next 25 years (Schubert, 1971, p. 102). This forecast is supported by many experts in the nuclear energy field. Thus, in spite of the current oversupply of uranium and the possible development of breeder reactors, large new reserves will be required. In 1988 the Alaska Ceological Survey began a study of uranium mineralization to encourage prospecting for radioactive deposits in Alaska, which still is relatively unexplored for uranium. In 1970 an investigation was conducted in Southeastern Aliska, because this region contains an important uranium-thorium mine and several radioactive prospects. Figure 1 shows the Incations of 14 areas visited.

These were selected on the basis of known radioactivity, favorable geology, or reports of radioactivity received from prospectors. However, this report is by no means a complete evaluation of the uranium potential in Southeastern Alaska. Rugged terrain, dense vegetation, and heavy rainfalt inhibited field work, so that only the more accessible areas were examined.

\section{REGIONAL SETTING AND MINERAL PRODUCTION}

Southeastern Alaska is the panhandle extending from $54^{\circ} 30^{\prime}$ to $60^{\circ} \mathrm{N}$. latitucie. It includes a narrow strip along the mainland and more than 1,000 islands in the Alexander Archipelago. The entire region is part of the western Cordillera. The outstanding geologic features include late Mesozoic intrusive masses forming the northwest-tronding Coast Range batholith and smaller subsidiary intrusives. The batholith is complex, and consists of a variety of igneous rocks of slightly different ages. 'The geology of the region has been complicated by tectonic activity since early Paleozoic time. Metamorphism of pre-Tertiary rucks is widespread. Major high-angle faults, with lateral displacements of many miles have determined the locations of numerous canals and inlets.

Ore deposits in Southeastern Alaska occur near intrusive rocks. The most important ones are concentrated in four general areas (fig. 2). These include (1) the Juneau gold belt extending for approximately 125 miles along or near the coast from Berners Bay to Windham Bay, (2) the Chichagof gold district on the northwestern part of Chichagof Island, (3) the Hyder silver-lead-gold-tungsten district at the easternmost tip of Southeastern Alaska, and (4) eastcentral and southeastern Prince of Wales Island and the adjoining Ketchikan area, which contain mostly copper, with some gold, uranium, silver, and lead. 


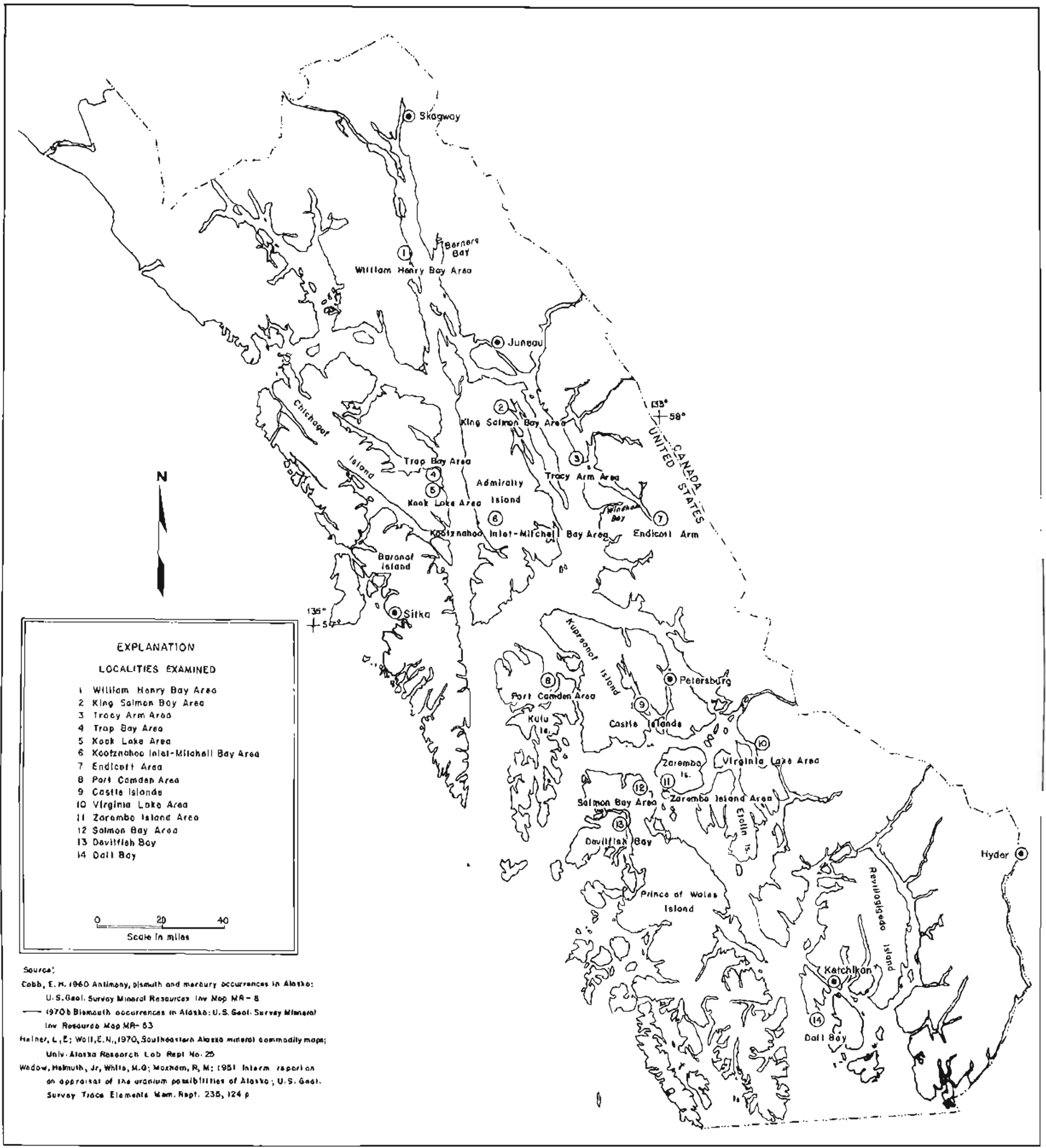




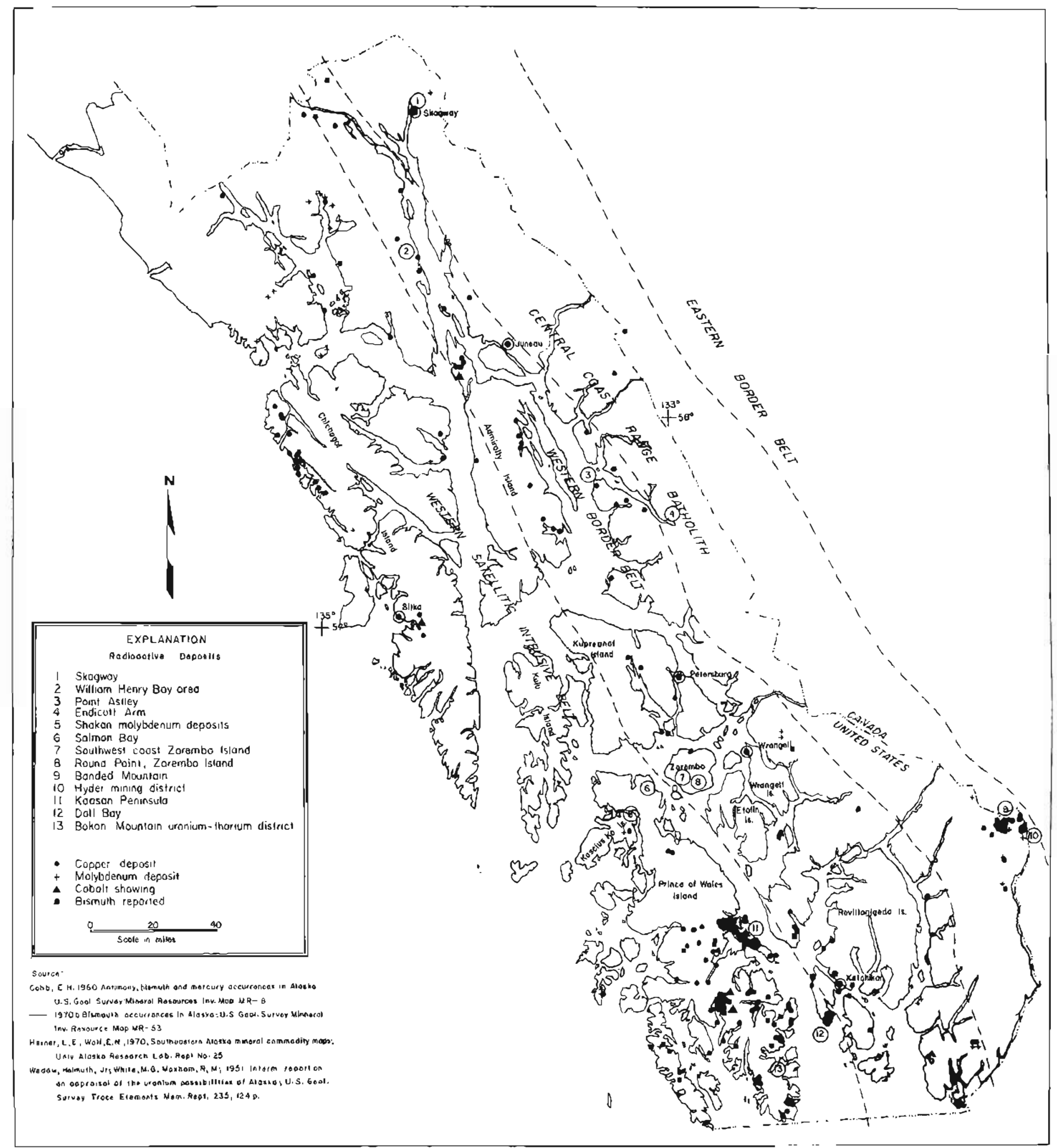


Between 1906 and 1956 Southeastern Alaska yielded 6.2 million ounces of goid, 3.3 million ounces of silver, 37 million pounds of copper, 48.3 million pounds of lead, 111 thousand pounds of zinc, and 14 thousand ounces of the platinum group of metals, mainly palladium (Kaufman, 1958, p. 7). Other ores mined or located contain antimony, barite, garnet, iron, molybdenum, titanium, tungsten, and recently, uranium and thorium.

\section{PREVIOUS INVESTIGATIONS}

During the intensive search for uranium in the late 1940's and early 1950's, the U.S. Geological Survey on behalf of the Atomic Energy Commission investigated numerous mines and placer deposits in Alaska for radioactivity. Reports pertaining to reconnaissance in Southeastern Alaska were made by Bates and Wedow (1953), Houston (1952), Houston, Bates, Velikanje and Wedow (1958), Matzko and Freernan (1963), Wedow, White, and Moxham (1951), West and Benson (1955), and White, West, Tolbert, Nelson, and Houston (1952). MacKevett (1963) made a thorough study of the uranium-thorium district at Bokan Mountain on Prince of Wales Island. Cobb (1970a) has compiled an index of uranium, thorium, and rare-earth elements known in Alaska. Reports on radioactive deposits in Southeastern Alaska by the Alaska Territorial Department of Mines include those by Fowler (1949) and Williams (1952a,b,1955a,b,c,d, and 1956). Reports by the Alaska Geological Surveys include those of Eakins (1969, 1970). Exploration by major companies and numerous private parties has included radiometric surveys, but the results are not available to the public.

\section{ACKNOWLEDGEMENTS}

Claude Williams assisted the authot during the 1970 field season and had charge of geochemical sampling. Prospector Bill Huff of Ward Cove, Alaska, was very generous with his time and knowledge of the geology of Southeastern Alaska and directed the author to several areas of interest. Various members of the U.S. Geological Survey encouraged the project with helpful discussions on the geology of uranium.

\section{TYPICAL URANIUM DEPOSITS OR OCCURRENCES}

Areas having significant radioactivity in Southeastem Alaska are shown on figure 2 and listed in table 1. Various modes of occurrence have been found. For example, radioactivity is associated with sulfide ore veins in the Hyder mining district, carbonate veins at Salmon Bay, pegmatite pods at Endicott Arm and Dall Bay, aplite and pegmatite dikes in the Bokan Mountain cistrict, and granitic stocks at Bokan Mountain and William Henry Bay.

The study of many radioactive veins throughout the world has shown that uranium is of ten associated with ores of cobalt, lead, silver, copper, and bismuth. The most characteristic gangue minerals are bematite and fluorite. Because of its mobility, uranium is most frequently concentrated near the outer borders of mineral districts and near the margins of intrusive bodies. These associations may also serve as general guides in the search for uranium in Alaska.

\section{VEINLIKE DEPOSITS}

Vein deposits are of particular interest in Southeastem Alaska because high-grade uranlum ore has been produced from a hydrothermal deposit at Bokan Mountain-near the southem end of Prince of Wales Island (fig. 2, loc. 13). This deposit consttutes the main stimulus for uranium exploration in Southeastem Alaska. The geology of the area has been mapped and described in detail by MacKevett (1963). The following description of the Bokan Mountain district is taken largely from that report.

The Bokan Mountain district covers about 70 square miles in the Kendrick Bay area. Uranium is associated with light-colored granitic rocks high in guartz and soda-rich minerals. The following four types of radioactive deposits have been found:

- A primary segregation of uranium-thorium minerals in a late stage of peralkaline granite magma emplacement and subsequent hydrothermal deposition. This type occurs at the Ross-Adams mine.

- Syngenetic deposits in pegmatite and aplite dikes.

- Epigenetc hydrothermal deposits, chiefly openspace filling, but with some replacement.

- A hydrothermal deposit formed in clastic sedimentary rock by filling of interstices at the Cheri No. 1 prospect. 
TABLE 1.-Areas in Southeastern Alaska with Significam Radionchivity

\begin{tabular}{lll}
\hline $\begin{array}{l}\text { Location on } \\
\text { Figure 2 }\end{array}$ & Area & $\begin{array}{l}\text { Geology and } \\
\text { Radiagctivity }\end{array}$ \\
\hline
\end{tabular}

$1 \quad$ Skagway

2

William Henry Bay, west side of Lyna Canal

3

4

5 Shakan-molybderum deposit. Kosciusko Island

6

Salmon Bay, Prince of Wales Island
Poivt Astley, east side of Stephens Passage

BBH claim, Endicott Arm
Country rock is quartz dirsite, altered rhyolite, and andesite dikes. Specks of fluorite and iron stain present in rhyolite. One hand-picked sample from clayey material had $1.26 \mathrm{U}$ but very scarce.

Widely scattered grains of euxenite and traces of thorianite present in an altered and brecciated granite stock which crops out over an area of one square mile. Material containing up to $1.2 \% \mathrm{eU}^{\circ}$ reported from the Lucky Six claims.

Pyrite, sphalerite, bomite, pyrrhotite, galena, covellite, and traces of native sllver in veins culting schist. A grab sample from a copper-silver deposil assayed $0.0068 \mathrm{eU}$.

Pegmatite pods in granodiorite, some pyrite and alteration. Samples collected in 1955 produced $0.04 \% \mathrm{eU}$. Samples collected in 1970 produced $0.004 \% \mathrm{U}$. A prospector reported fluorescent uranium minerals on top of ridge south of the head of Endicntt Arm.

Molybdenite, pyrite, pyrrhotite. chalcopyrite, sphalerite, and iron oxide in a breccia zone near the contact of Late Jurassic or Early Cretaceous diorite with Silurien graywacke. Maximum eU found was $0.044 \%$.

Radioactive carbonate veins cul Paleo'zoic graywacke and volcanics. Up to $0.13 \% \mathrm{eU}$, due mostly to thorium.
Fluorite veialets with pyrite cutting voleanic racks. Maximum eU in felsic volcanics was $0.005 \%$.

Mesozoic granite intruded into graywacke. Thin epidote veinlets. Radioactivity in granite of $0.004 \% \mathrm{eU}$ probably due 10 accessory minerals.
Freeman, 1963 , p. 30,33

Matzko and Freeman, 1903, p. 44; present report

Houston, Bates, Velikanie and Wedow, 1958, p. 25: Wedow and others. 1953 . p. 6

Huff, written communicution. 1970; Williams, 1955a: present report

Houston, Bates, Velikanje and Wedow, 1958, p. 24; Wedow and others, 1953, p. 9,10

Bates and Wedow, 1953 , p. 1, 8; Glover, 1951; Houston, 1952; Houston, Bates Velikanie and Wedow, 1958, p. 6-23; Wedow and others, 1953, p. $6,9,10$; White and others, 1952, p. 13, 14, 18; present report

White and others, 1952, p. 16; present report

Houston, Bates, Velikanje and Wedow, 1258, p. 2A; Wedow and others, 1953 , p. 10 
TABLE I.-Areas in Southeastern Aloska with Significant Radioactivity .Continued

Location on

Figure 2

9

10

$\$ 1$

12

13
Area

Banded Mountain, Hyder () Istrict

Hyder District

Kasaan Peninsula, cast coast of Prince of Wales Island

Dall Bay, south end of Gravina Lsland

Bokan Mountain District. Prince of Wales Island
Geology and

Radioactivity

A radiogetive sample from a coppermolybdenum prospect assayed $0.03 \% \mathrm{U}$.

Silver, gold, lead. zinc, molybdenum, and tin in veins in granodiorite, greenstone, and metasediments. Smalk anount of $U$ associated with hematite and the ores. A sample from the Mountain View mine assayed $0.045 \% \mathrm{eU}$, and lesser showings were found at other locations. An unvorificel assay of $0.7 \% \mathrm{eU}$ was reported for a sample from the Mountain View property.

Area has beon a smal) copper producer. Deposits contain chalcopyrite and magnetitc in a contact zone between granodiorite stocks and nuetasedimcnts and limestonc. Hematite, bontite and secondary copper minerals also present. One sample, the source of which is uncertain, but believed to be from Kasaan Peninsula assayed 0.18 tue to allanite and a copper uranite.

Pods of radinactive feldspar in sclsist have up to $0.078 \mathrm{U}$.

The Ross-Adams mine has yielded uranjum and thorimm ore from a deposit in a perałkaline granite stock. Small samples have assayed up to 32 U308. Past production has averaged almost $1.0 \% \mathrm{U}$ and $1.0 \%$ thorium. Ore minerals are urazothorite and uranoan thorianite.
References

Samples rcoived from ].

W. Huff, 1970

Fowler, 1949, Houston. Hates, Velikanje and Wollow, 1958, t). 25-29; Wedow and others. 1951 . p. 54, 55: West and Benson, 1055, p. 27-45: Williams, 1952A

Wedow, 1951, p. 63; White and others, $1952 \mathrm{p}$. 18

Williams, 1856; present report

Eakins, 1970: Frecman, 1983, n. 44-48; Mackevett, 1983 ; Williams, $1955 \mathrm{c}$
The principal ore deposit in the Bokan Mountain area is at the Ross-Adams mine, which was discovered in 1955 near the head of Kendrick Bay by Don Ross and Kelly Adams using an airborne geiger counter. While the ore is not in a vein, it is a hydrothermal deposit. "The ore is a uranium-thorium concentration in a peralkaline granite stock, which is roughly circular and about two miles in diameter. It forms prominant outcrops at Bokan Mountain.

The peralkaline granite is an unusual variety of igneous rock characteristically high in quartz and the sodium-bearing pyroxene (acmite) and amphibole (riebeckite), which may be present in amounts up to 12\%. It is generally light gray with an average of about
$10 \%$ dark minerals. Accessory minerals are chiefly zircon, uranothorite, pyrite, xenotime, fluorite, cordierite, and magnetite. Unusual amounts of the minor elements, uranium, thorium, yttrium, lanthanum, niobium, cerium, and other rare earths are present. Aplite and pegmatite dikes genetically related to the Bokan Mountain granite are interesting because some contain uranium, thorium, zirconium, and niobium. Lead-alpha and potassium-argon measurements show the granite to be Late Triassic or Early Jurassic in age (Lamphere, MacKevett, and Stern, 1964). The peralkaljne granite stock has been intruded into an older pluton of diorite and monzonite of Ordovician age. 
The Ross-Adams ore body is an irregular pipelike body that plunges generally southward. The percentage of uranium minerals decreases gradually outward from a high-grade core, and ore limits are indefinite. Ore mined from an open pit originally contained a high-grade core which averaged over $0.5 \%$ $\mathrm{U}_{3} \mathrm{O}_{8}$. A large portion contained $18 \mathrm{U}_{13} \mathrm{O}_{8}$, and pods contained up to $3 \% \mathrm{U}_{3} \mathrm{O}_{8}$. Twelve samples analyzed by the U.S.G.S. yielded from 0.18 to $3.2 \%$ uranjum. High-grade ore can be distinguished by its dark color due to the presence of associated hematite in the granite. The core was surrounded by a zone of lowergrade ore 2 to 20 feet thick that averaged less than $0.5 \%$ $\mathrm{U}_{3} \mathrm{O}_{8}$. Information is not available on the tenor of the ore mined later by underground methods or on new ore discovered by recent drilling.

Almost all the ore minerals are primary. They occur both as grains scattered throughout the peralkaline granite and in numerous thin $(0.1$ to $0.8 \mathrm{~mm})$ veinlets. Anhedral to euhedral grains up to $2 \mathrm{~mm}$ wide are typical. The dominant ore minerals are uranothorite (uranium-bearing thorite) and uranoan thorianite (uranium-bearing thorianite). Coffinite, $\mathrm{U}\left(\mathrm{SiO}_{4}\right)(\mathrm{OH})_{4}$ is found in minor amounts. Other vein minerals accompanying the ore minerals are abundant hematite and calcite, and lesser amounts of fluorite, pyrite, limonite, galena, quartz, clay minerals, and chlorite.

There is no sharp boundary between the ore and the host granite. The ore zone contains slightly more iron, lead, aluminum, zirconium, titanium, magnesium, calcium, manganese, and arsenic, but less quartz and potassium than the surrounding rock. Most of the ore is out of radioactive equilibrium, but the thorium combines with the uranium in such a way to give the effect of apparent equilibrium.

A total of 60,000 tons of ore averaging almost 18 of both $U_{3} \mathrm{O}_{8}$ and thorium has been produced by various operators of the Ross-Adams mine by underground and open pit methods. The mine was closed between 1964 and early 1971, when Newmont reopened it. Drilling by Newmont has proven the presence of ore beyond previously known limits and has shown that the structure of the deposit is much more complicated than had been suspected.

Uranium-thorium minerals have been found in small amounts at some other prospects in the area. These minerals include uraninite, uranophane, allanite, possibly davidite or brannerite, and ellsworthite. Only minor amounts of the secondary uranium minerals gummite, sklodowskite, beta uranophane, bassetite, and novacekite have been reported from the Ross-Adams property. 'The scarcity of secondary uranium minerals is undoubtedly due to their solubility and the heavy rainfall in the area.

Some claims and prospects in the district are near altered dacite dikes in albitized zones along the margin of the peralkaline granite. Others are on small pegmatite dikes within the granite. Most of these claims are only slightly explored. One prospect was located for fluorite. About eight miles southeast of Bokan Mountain, weak anomalies occur in pegmatites near Gardner Bay. Low radioactivity has been found in altered andesite dikes cutting syenite near Stone Rock Bay about three miles south of Gardner Bay. None of the more common metals associated with the Bokan Mountain uranium-thorium ores appear to be present in commercial amounts, but old copper and gold prospects have also been worked in the past, mostly around Gardner Bay, McLean Arm, and Mallard Bay, 25 to 30 miles southeast of Bokan Mountain. It is possible but not proven that the uranium-thorium ore is related to the copper district on the island (fig. 2).

\section{DEPOSITS IN SEDIMENTARY ROCKS}

Ninety-five percent of the uranium reserves in the United States are in nonmarine sandstone and conglomerate formations of Triassic and Jurassic ages in the Colorado Plateau region and in Tertiary basins in Wyoming. Host rocks for bedded uranium deposits in the western United States characteristically are nonmarine, arkosic, often carbonaceous sandstones and conglomerates derived from ancient granites. In some districts they are overlain by acidic volcanic ash or tuff. The ancient granites and volcanic ashes are considered to be the sources of the uranium. This is thought to have been removed by weathering and solution, transported by meteoric water into the sandstones and concentrated in certain beds or at solution "fronts" under proper reducing conditions.

Some of the conditions necessary for this type of deposit are present in Alaska, where nonmarine, arkosic, and carbonaceous Tertiary sandstones and conglomerates have been deposited in basins near granjtic mountains. Volcanic ash and tuffs also are present in some areas. On the other hand, factors possibly unfavorable to the formation or detection of uranium deposits in Tertiary sandstones of Alaska are: (1) high annual precipitation, especially in Southeastem Alaska where the rainfall is generally over 100 inches a year, (2) relatively steep dips in contrast to comparatively flat-lying beds of the westem states, (3) apparent lack of pyrite and trace elements commonly associated with ore-bearing 
formations of the western United States, and (4) climatic changes since T'ertiary time leading to the presence of permafrost in some Alaskan basins. In any case, very little has been done to investigate the uranium potential of Tertiary sandstones in Alaska, and apparently there has been no drilling to test these formations at depth other than in the Cook Inlet petroleum province.

Throughout Southeastern Alaska, Tertiary beds overlie Mesnzoic and (or) Paleozoic rocks with a pronounced unconformity. Dips vary from $8^{\circ}$ in some places at Port Camden to $60^{\circ}$ south of Kootznahoo Inlet. The sandstones and conglomerates are poorly sorted, compact, unmetamorphosed, and crossbedded. They consist of an assortment of rock detritus which includes quartz, shale, phyllite, and volcanics. Interbedded coal lenses and plant fossils are common.

Tertiary sediments remain today in the following areas:

- The Kootznahoo Inlet-Mitchell Bay area near Angoun on the west side of Admiralty Island, where approximately 36 square miles are underlain by sandstones and conglomerates with small amounts of shales and cual;

- Little Pybus Bay on the southeast side of Admiralty Island, which contains about 5 square miles of sandstone;

- Port Canden area on Kuiu lsland, which contains the most complete section of Tertiary heds; and the nearby Hamilton Bay area of Kupreanof Island;

- Cleveland Peninsula near Ketchikan, where sediments are exposed for a short distance along shore;

- Coal Bay on the south side of Kasaan Bay, Prince of Wales Island; and

- Zarembo Island, along the southwestern coast.

Sedimentary rocks possibly correlative with the sandstones of the Kootznahoo Inlet area are exposed on Pleasant Island in Icy Strait north of Chichagof Island.

In the present study, only three areas of Tertiary sandstones were examined. For the report they are described later under the titles: Kootznahoo InletMitchell Bay area, Admiralty Island; Port Camden Area, Kuiu Island; and Zarembo Island Area.

The Tertiary rocks in these six areas consist of volcanics and continenta! sandstones and conglomerates. The volcanics, including flows, sills, agglomerates, and breccias, are more widespread than the sandstones. In some places the volcanic rocks are interbedded with or overlie the sandstones. The sandstones and conglomerates in Southeastern Alaska occupy troughs created during Paleocene through Miocene time. Though now separated, these strata may once have been parts of a more or less continuous deposit over an extensive area. The sandstone formation of the Kootznahoo Inlet-Mitchell Bay area is probably 5,000 feet thick. A map by Brew, Loney, and Muffler (1966, p. 185) shows an interpretation of Tertiary paleogeography in which a belt 200 miles long and about 30 miles wide is inferred to have extended from the northern part of Admiralty Island to the middle of the western side of Prince of Wales Island. The map shows a core of volcanic rocks surrounded by sandstones and conglomerates.

\section{URANIUM IN PEGMATITE DIKES}

Quartz and alkali feldspars frequently scparate from cooling magmas to form pegmatite dikes, which may contain concentrations of rare metals, including thorium and uranium. This type of deposit may produce some fine specimens and small amounts of high-grade radioactive material, but there are few pegmatites in the world mined for uranlum and so far none in Alaska (Sainsbury, 1957). In the Bokars Mountain uranium-thorium district, radioactivity has been found at scattered prospecls in pegmatite dikes as well as in aplite and dacite dikes. Radioactive pegmatites have also been discovered at the BBH claim on Endicott Arm and in pods of feldspar at Dall Bay. These localities were visited during 1970 and are described below under appropriate titles. Regardless of composition, such dikes are probably most valuable as indicators or guides to possibly more extensive deposits rather than being of commercial value in themselver.

\section{MISCELLANEOUS DEPOSITS}

Three localities (not listed in table 1) where radioactivity was very low, but where the mineralogy was favorable or rare-earths were detected, may have possibilities for uranium. These are:

Admiralty 1sland, 5 miles west-southwest of the head of Seymour Canal (King Salmon Bay area). Yttrium, zirconium, niobium, thorium(P) and the rare-earth elements lanthanum, cerium, praseodymium, and neodymium were detected by $\mathrm{X}$-ray spectroscopic analysis of heavy minerals from pegmatite veins (Lathram, Pomeroy, Berg, 
and Loney, 1985, p. R43, R45).

- Sandy Cove prospect at Glacier Bay. Quartz monzonite bedrock contains allanite plus copper, gold, silver, molybdenum, and bismuth in a mineralized zone (Mackevett, Brew, Hawley, Huff, and Smith 1967, p. 114-115).

- Goddard Hot Springs area, west side of Baranof Island. Stream gravel concentrates yielded from 0.012 to $0.016 \%$ equivalent uranium, probably due to thorium in allanite. Radiometric surveys located no radioactive mineral concentrations, but the background over granite areas was considerably above that of metasedimentary rocks (West and Benson, 1955, p. 47-49).

\section{SUGGESTIONS FOR PROSPECTING}

In general, igneous rocks that are late-stage differentiates of granite or syenite, including leucogranite, late rhyolite, aplite, alkalic syenite, and phonolite, bave been found to contain the greatest amount of uranium (Faul, 1954, p. 88). Also, uranium is more often found at the border zones of batholiths and peripherial to mineralized districts.

Intrusive rocks are scattered throughout Southeastern Alaska (fig. 3), but geologic mapping of some portions is incomplete or does not distinguish the more acidic granites from the intermediate igneous types. Thus, the most favorable rock types cannot generally be pinpointed from published maps alone, and considerable field work is sormally required.

Veins containing copper, lead, silver, cobalt, and nickel should be checked for radioactivity. In British Columbia, molybdenite is found to be the sulfide most commonly associated with uraninite (Stevenson, 1951, p. 362). Hematite (both the specular and the red varieties, including hematitic jasper and fluorite are probably the most universal gangue minerals associated with uranium deposits.

The fact that commercial radinactive ore has been found in a soda-rich granite in Southeastern Alaska suggests that similar granites offer the most potential in the region. Exploration can be guided by geologic data that indicate the location of acid rocks intruded at shallow depths subsequent to major orogenic activity, especially those high in soda-rich feldspars, amphiboles, and accessory minerals, and granites having zones or borders displaying albitization. Sodarich granites have also been noted to be favorable for uranium in other areas outside Alaska (Clark and Washington, 1924, p. 107; Faul, 1954, p. 84, and table 2.2.2; Lang, 1949 , p. 83. The alkalic syenite near
Tenakee Inlet on the east side of Chichagof Island may offer possibilities.

Areas to consider for uranium exploration in Southeastern Alaska should include the intrusive rocks bordering mineralized districts especially the Ketchikan-Prince of Wales Island copper district, the Chichagof copper mining area, and the Hyder district. However, widespread distribution of radiometric showings and sulfide mineralization in Southeastern Alaska indicate that no part of the region can be completely eliminated from prospecting for uranium deposits.

While the characteristics of Tertiary sandstone and conglomerate in Southeastern Alaska do not appear to be favorable for commercial uranium deposits, anomalous radioactivity was detected at a few places. There is no information to indicate that the beds have been tested at depth.

Aerial radionetric surveys from low-flying aircraft are the most rapid means of prospecting large areas, but because of the ruggedness of Southeastern Alaska, the method has its limitations. Ceochemical techniques are applicable in some areas. Streamsediment, soil, and mulch samples can be analyzed for uranium to a sensitivity of $1 \mathrm{ppm}$. Geobotanical prospecting and the analysis of ashed plant material may be useful in outlining a uranium deposit beneath soil. Field work by the author (Eakins, 1970) at the Ross-Adams mine has shown that the deposit has a strong expression in stream sediments and several types of organic material, especially lodgepole pine.

\section{INVESTIGATIONS BY THE DIVISION IN 1970}

\section{WILLIAM HENRY BAY AREA}

\section{LOCATION AND ACCESS}

The Lucky Six Claim Group, hereafter referred to as Lucky Six claims, is located on the west side of Lynn Canal, approximately 42 miles northwest of Juneau (figs. 1,4 ). These claims lie between 1,500 and 2,000 feet above sea level on a ridge $1-1 / 2$ miles south of Endicott River and 2 miles north of the mouth of Willian Henry Bay. It is a steep, difficult climb on foot from the coast. But above 1,500 feet, the claims are mostly above timber line and the bedrock is exposed in many places. The locality was visited in early June, and about two-thirds of the area occupied by the claims was still snow-covered, prohibiting full examination of the ground. 


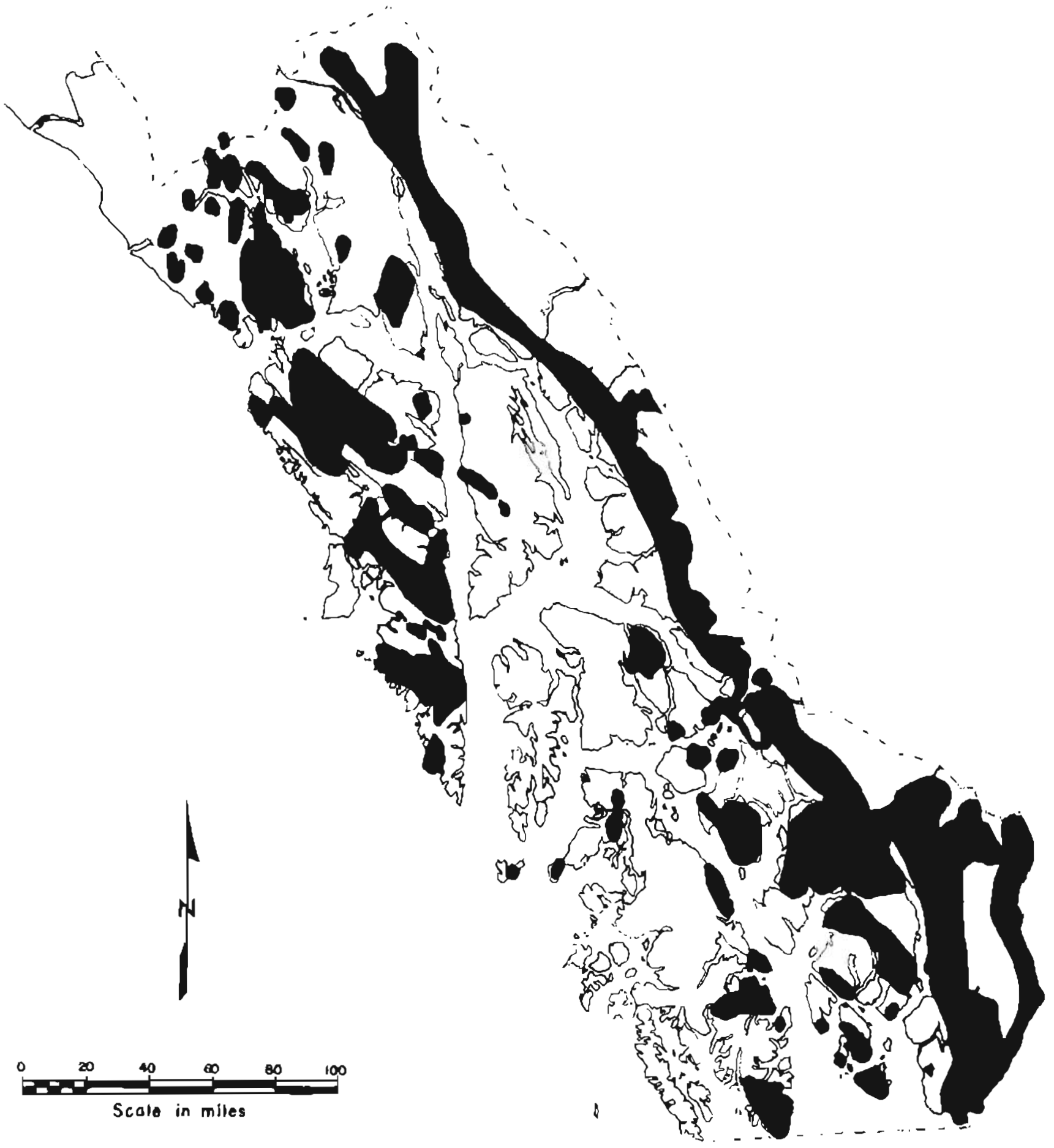

Figure 3 Acid and intermediate intrusive rocks, Southeastern Alagka 


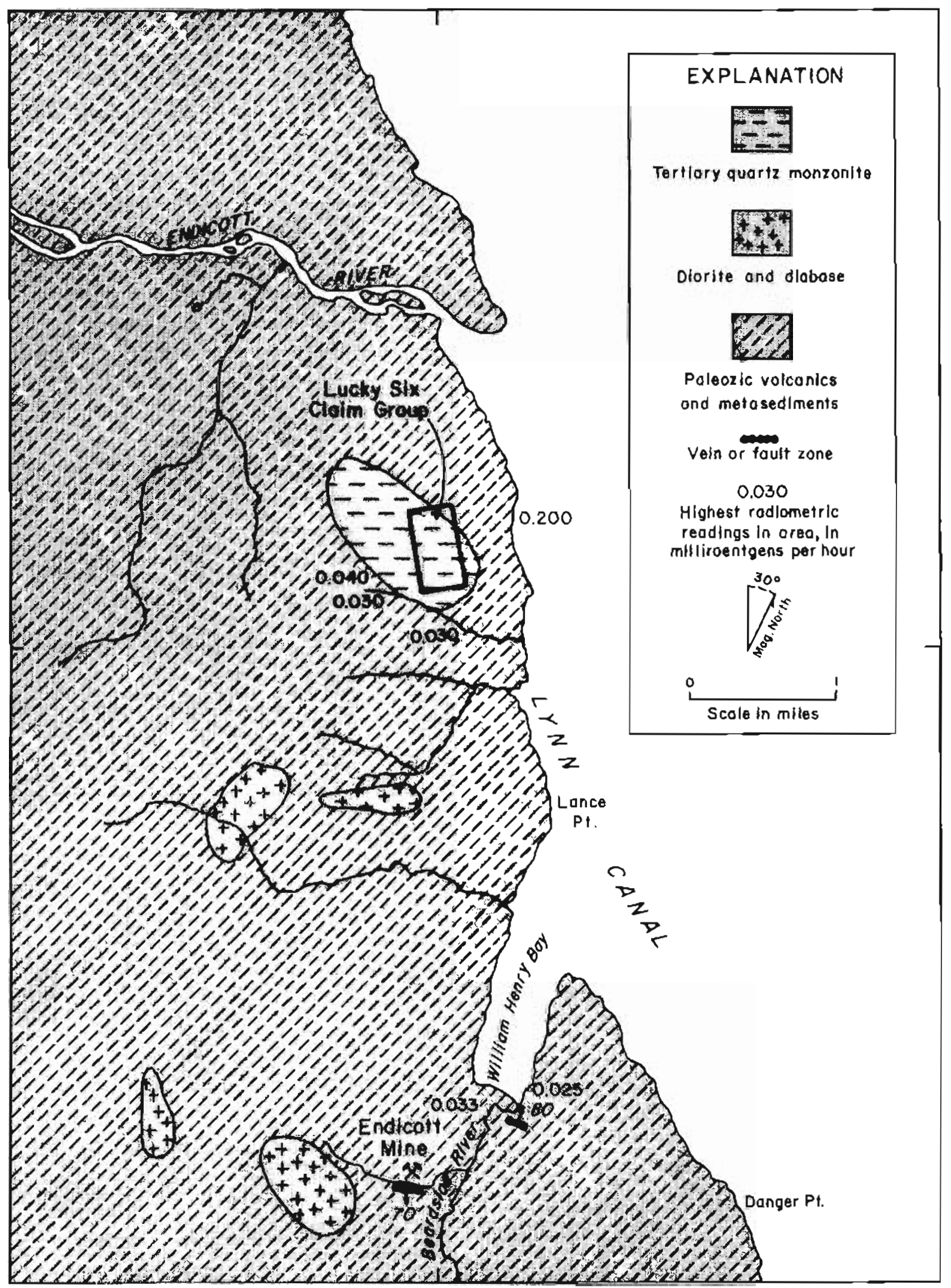

Base from U. 5. Geologlcal Survey

$1: 63,36$ n Juneou C-4,1948;D-4,1953

Geology odapted from Lathram, Loney, Condon and Berg, 1959

Figure 4 Lacations of veins, intrusive rocks, radiometric readings, and Lucky Six claim group, William Henry Bay area (fig. 1, ar i 1 ) 


\section{HISTORY}

A radioactive anomaly was detected from the air by prospectors during the 1950's. Shallow prospect pits, trenches, and one diamond-drill hole revealed mineralized material. One sample was reported to contain $0.20 \%$ eU (equivalent uranium), but a commercial deposit was not indicated.

\section{GEULOGY}

The area considered here lies between William Henry Bay on the south and the Endicntt River on the north. The geology of the area has been discussed by Berg (1960, p. B39); Herbert and hace (1964, p. 10; 1965 , p. 25-26); MacKevett (1957, p. 175); Matzko and Freeman (1963, p. 44); Mertie (1921, p. 109-112); and Twenhofel, Reed, and Gates (1949, p. 28-30).

The Lucky Six claims are situated on the southeastem edge of a small Tertiary quartz. monzonite intrusive that is exposed over an area of approximately three-fourths of a square mile. The intrusive is surrounded by Paleozoic volcanics and metasediments (fig. 4). The general strike of the strata and the dominant structures is north to northwest. However, the genlogy is complex, the rocks are metamorphosed, and subordinate cast-west faults cut the major structures.

About 1/2 mile south of the mouth of the Endicott River, a predominantly carbonate sequence containing argillite and basalt dikes is in contact with an altered sequence of volcanics to the south. The contact is well-exposed on the coast and appears to be a northwest-trending fanlt. Small diorite and diabase intrusives lie west and north of William Henry Bay.

\section{MINEAAL DEPOSITS}

Two prospect pits on the Lucky Six claims (fig. 5) expose zones containing soft, vuggy, black- and redstained fractured material. No well-defined veins were vísible, but a prominent fracture in pit No. 2 strikes $\mathrm{N} 5^{\circ} \mathrm{E}$ and dips $80^{\circ} \mathrm{W}$. Fractures in pir No. 1 also seem to trend northeast. The intrusive underlying the claims is a light-gray porphyry with feldspar crystals up to $1-1 / 2$ inches long. There is an abundance of altered mica throughout the rock, which is especially noticeable on fractures and in vugs. Some brecciated, fine-grained, silicenus rock was found on the surface 150 feet southwest of pit No. I, which may represent an extension of a crushed zone from that pit. Traces of thorianite in small red patches were reported by Matzko and Freeman (1963), and scattered grains of euxenite were reported by MacKevett (1957). Rare earths were found by Lathram, Loney, Condon and Berg (1959) in a sample containing pyrite, chalcopyrite, galena and sphalerite.

Copper ore has been mined from the Alaska Endicott Mining and Milling Company mine located in the valley $3 / 4$ mile southwest of the head of William Henry Bay at an elevation of 160 feet (fig. 5). Development was done between 1916 and 1920 . The ore zone cuts greenstone country rock and consists of an irregular quartz-calcite brecciated zone averaging 10 feet wide. The strike is east and the dip averages $80^{\circ}$ $\mathrm{S}$. The ore mineral was chalcopyrite. Pyrite and traces of gold and silver were also present. Underground work consisted of 1800 feet of tunneling and some stopes. Other copper claims have been staked on the south side of William Henry Bay and near Lance Point on the north side of the bay.

A 200-square-mile area with widely distributed gossans north of the Endicott Hiver was reported by Berg (1980). The gossans contain showings of cobalt, copper, zinc, and lead. Berg indicated that they have not been adequately expłored.

\section{RADIOMETRIC SURVEY}

Foot traverses with a scintillometer showed the intrusive on which the Lucky Six claims are located to have an overall anomalous amount of radioactivity. The radiumetric response increased from $0.01 \mathrm{mr} / \mathrm{hr}$ (milliroentgens per hour) or less on the volcanic rocks along the coast to $0.04 \mathrm{mr} / \mathrm{hr}$ on the intrusive. The average in the area of the claims was about $0.03 \mathrm{mr} / \mathrm{hr}$, but readings to a maximum of $0.20 \mathrm{mr} / \mathrm{hr}$ were obtained in the bottom of prospect pit No. 2. Wherever the scintillometer was placed in a hole or pit, a pronounced increase in radioactivity was recorded because of the mass effect of the bedrock.

A radiometric survey was made of the Lucky Six No. 1 claim and part of the Lucky Six No. 4 claim using a Detectron Model DG-7 geiger counter. This instrument is not as sensitive as the scintillometer, but the readings ranged from 0.015 to $0.200 \mathrm{mr} / \mathrm{hr}$ (fig. 5). Three samples taken by the author from prospect pits Nos. 1 and 2 were assayed for uranium and yielded 27 , $\mathrm{U}$, and $8 \mathrm{ppm} U$. These values may be compared with the average of 4 ppm for acid igneous rocks.

A fault zone near the head of William Henry Bay gave an increase in response up to $0.033 \mathrm{mr} / \mathrm{hr}$ from the nearby background of $0.012 \mathrm{mr} / \mathrm{hr}$. This locality is discussed under Geochemistry. Ore from the mill ruins near the old Endicott Mine did not show any radiosctivity. 


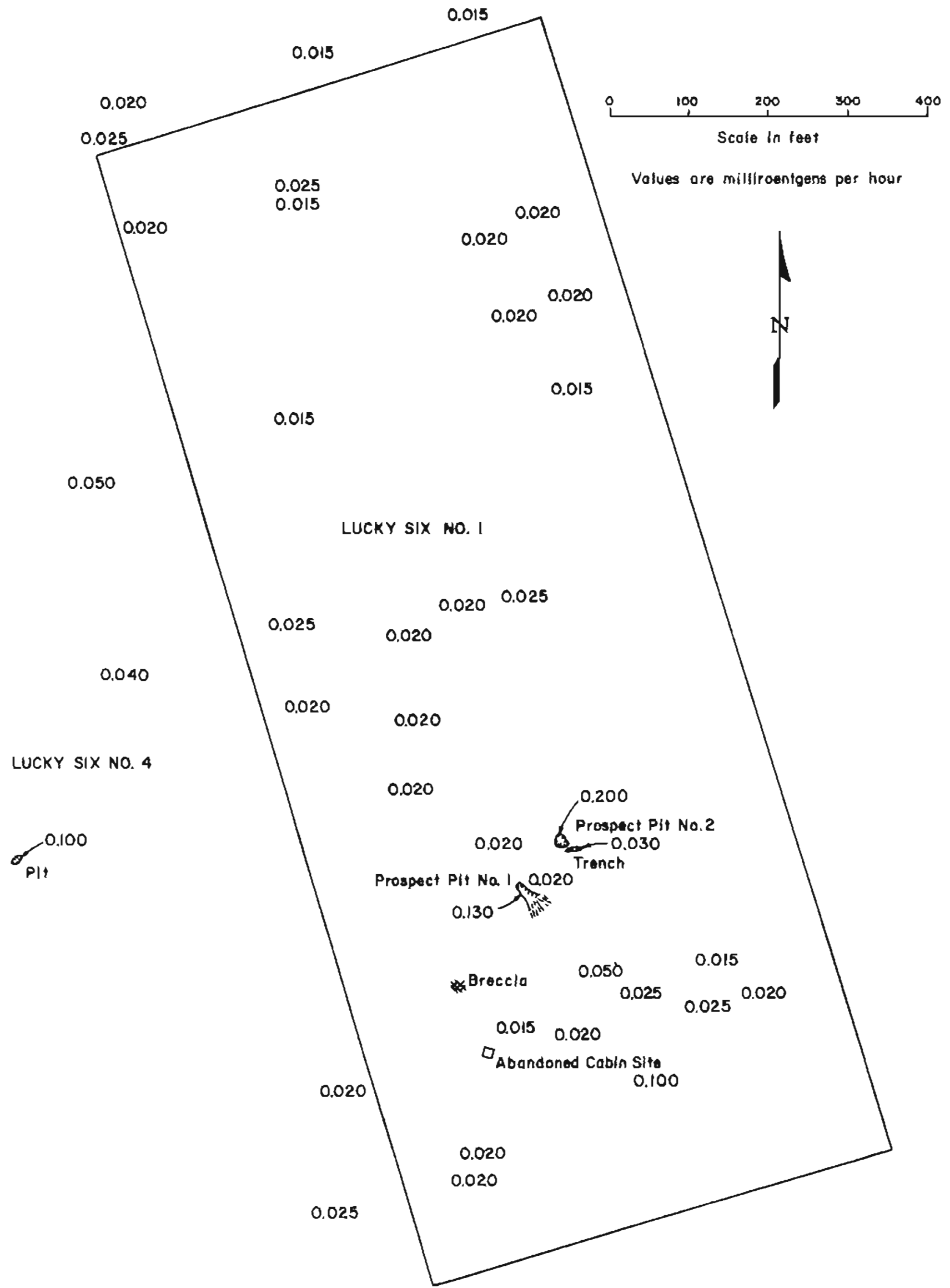

Figure 6 Radiometric survey on Lucky Six No. 1 claim 


\section{GEOCHEMISTRY}

Six stream-sediment samples and one soil samplè were collected on the south side of the Lucky Six claims. Eleven stream-sediment samples were also colleeted from the William Henry Bay area (fig. B). Atomic absorption analyses are given in table 2. Histograms appear in figure 7. Anomalous values from samples taken near the Lucky Six claims were as follows: copper, 140,160,175, 180, and 190. The copper anornalies may be derived from disseminated minerals in the intrusive. The stream, however, was not followed above 1,450 feet, and it is possible that veins exist higher in the drainage.

TABLE 2,-Atomic Absorption Analyses, Willinm Henry Bay Areo (anomalous values underlined)

\begin{tabular}{|c|c|c|c|c|}
\hline $\begin{array}{l}\text { Location on } \\
\text { Figure } \theta\end{array}$ & $\begin{array}{c}\text { Field } \\
\text { Sample } \\
\text { Number }\end{array}$ & $\begin{array}{c}\text { Copper } \\
\text { ppm }\end{array}$ & $\begin{array}{l}\text { Lead } \\
\text { ppm }\end{array}$ & $\begin{array}{l}\text { Zinc } \\
\text { ppm }\end{array}$ \\
\hline \multicolumn{5}{|c|}{ (Lucky Six Claim Group) } \\
\hline 1 & 13.3 & 210 & 30 & 150 \\
\hline 2 & PI2 & 140 & 20 & 75 \\
\hline 3 & P13 & $\overline{175}$ & 40 & 80 \\
\hline 4 & P2 & $\overline{190}$ & 35 & 130 \\
\hline 5 & $P[]$ & $\overline{40}$ & 85 & 85 \\
\hline 6 & Pl & $\underline{160}$ & 35 & 120 \\
\hline 7 & $\psi_{4}$ & $\underline{180}$ & 40 & 120 \\
\hline \multicolumn{5}{|c|}{ (Williain Henry Bay Area) } \\
\hline 8 & $\mathrm{P} 10$ & - 45 & 20 & 135 \\
\hline 9 & $r \theta$ & 45 & 30 & 170 \\
\hline 10 & P8 & 45 & 20 & 255 \\
\hline 11 & 17 & 35 & 20 & $\overline{130}$ \\
\hline 12 & El & 55 & 15 & 100 \\
\hline 13 & $\mathrm{E2}$ & 55 & 70 & 2000 \\
\hline 14 & E3 & 35 & 85 & 670 \\
\hline 15 & E4 & 60 & 90 & 2700 \\
\hline 18 & ES & 55 & 45 & 1350 \\
\hline 17 & P5 & .55 & 60 & 1850 \\
\hline 18 & $P 8$ & 45 & 140 & 1500 \\
\hline
\end{tabular}

High zinc values were obtained from sediment samples taken from a stream near the head of Wiltiam Henry Bay draining the ridge on the south side. This anomaly has been reported previously (Herbert and Race, 1964, p. 10, 11, 1965, p. 25-27). Five samples (fig. 6 , locs. 13-17) collected from this stream in 1970 produced zinc values of 670 to $2,700 \mathrm{ppm}$, copper 35 to $60 \mathrm{ppm}$, and lead 40 to $65 \mathrm{ppm}$. Sampling was done only to an elevation of 225 feet. A fractured iron. stained zone near the mouth of the stream probably represents east-west fault. A single sample collected near the mouth of the next stream southwest (fig. 6 , loc. 18) yielded a zinc value of $1,500 \mathrm{ppm}$, copper 45 ppm, and lead $140 \mathrm{ppm}$. Two samples (fig. 6, locs. 9 and 10) collected from the northwest side of the bay, were slightly anomalous for zinc.

\section{CONCLUSIONS}

The small quartz monzonite in trusive just discussed has not been found to be commercial at or near the surface, but the amount of drilling done was probably insufficient to properly evaluate the area. The zinc anomaly obtained in streams draining the ridge south of William Henry Bay is very pronounced, and a copper anomaly is present in the stream south of the Lucky Six claims. It is not known if they have been prospected or sampled more extensively, but on the basis of the anomalies, the upper parts of the drainages in both areas should be examined and sampled.

\section{KING SALMON BAY AREA, ADMIRALTY ISLAND}

\section{LOCATION AND ACCESS}

The area investigated lies on a subsidiary peak between 1,500 and 3,000 feet elevation 3 miles west of the head of King Salmon Bay, on the northeastem part of Admiralty Island. It lies in the Juneau A-2 quadrangle, approximately 18 miles south of Juneau. A helicopter was chartered in Juneau for transportation to and from the locality.

\section{GEOLOGY}

A geologic map and bedrock descriptions by the $U$. S. Geological Survey (Lathram, Pomeroy, Berg, and Loney, 1965, p. R43) suggested to the author that a small felsic intrusive near King Salmon Bay should be examined for possible radioactivity.

West of the head of Seymour Canal an area of about 50 square miles of Paleozoic and Mesozoic migmatite, gneiss and schist contains, near its center, a felsic intrusive about a mile in diameter. The intrusive consists of allanite-biotite granite, biotite-quartz monzonite, and quartz-albite-microcline pegrnatite. Rare-earth elements and possibly a trace of thorium in pegmatite dikes were located less than 2 miles north of 
$135^{\circ} 30^{\circ}$

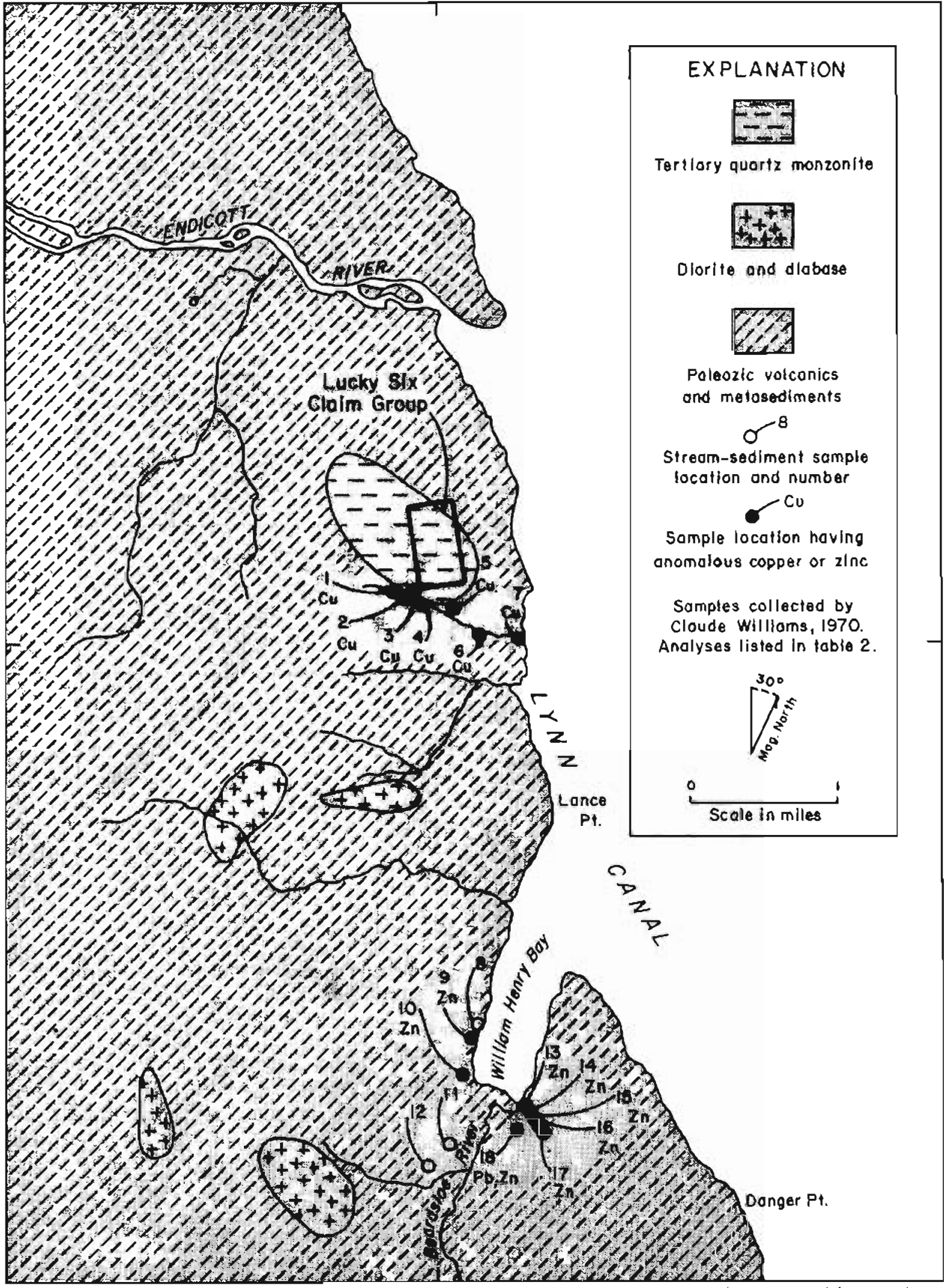

Base from U.S. Geologlcal Survey

Geology odapted from Lathram

1:63,360 Juneau C-4,1948; D- 4,1953

Loney, Condon and Berg, 1959

Figure 6 Locations of geochemical samples and intrusive rocks, Wiltiam Henry Bay area (fig. 1, area 1) 


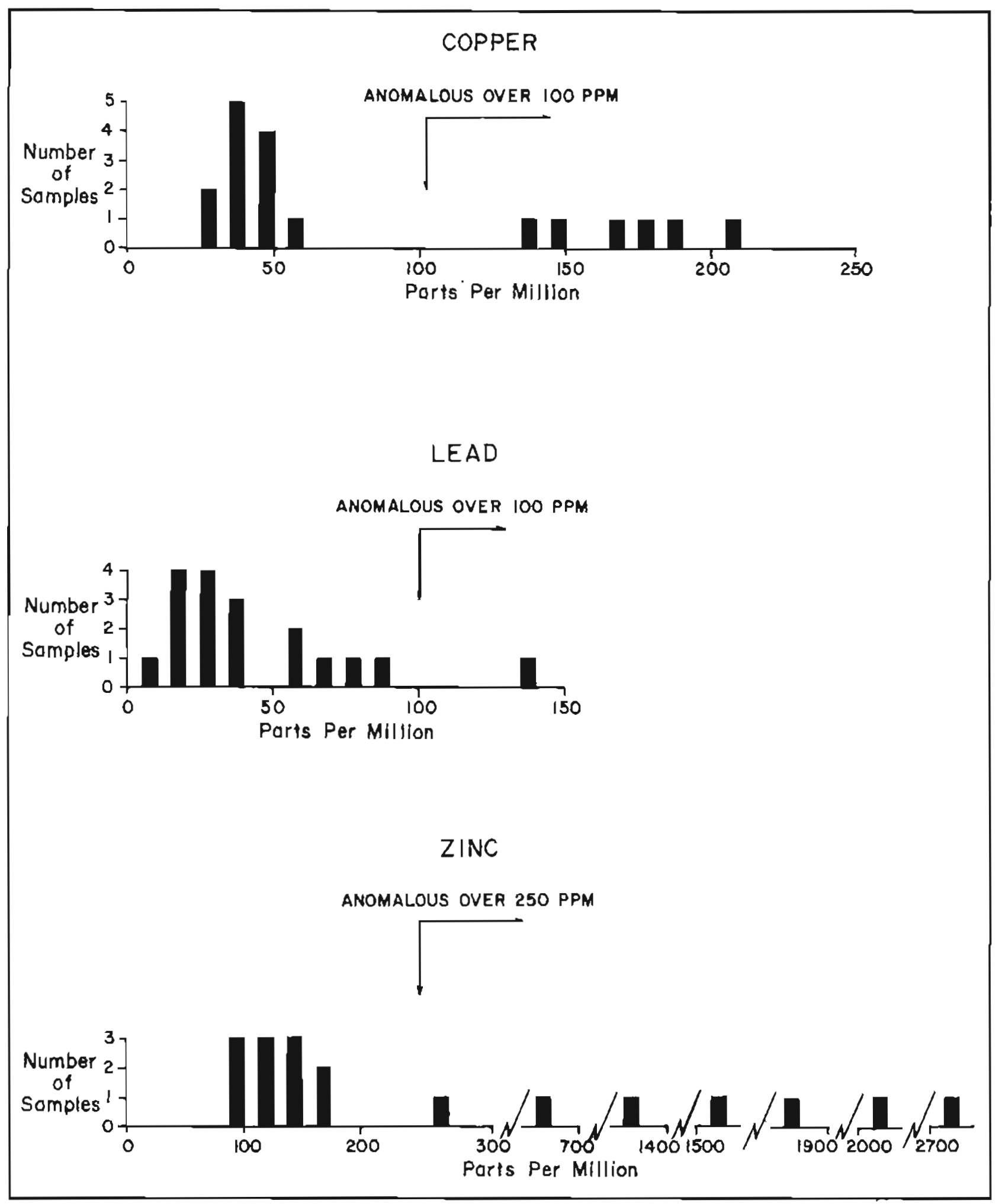

Figure 7 Frequency distribution histogram based on atomic absorption analyses for copper, lead, and zinc, William Henry Bay area 
the granitc (Lathram, Pomeroy, Berg, and Loney, 1965 , p. R43). That report plus knowledge of the composition of the granite intrusive suggested the possibility of uranium in the granitic rock. Some of the granitic outcrops weather nearly white. No sulfide minerals were found except a small amount of pyrite in migmatite ncar the margins of the intrusive. Iron staining was heavy near the head of a draw on the north side of the peak at 2,200 feet, and sinall veinlets and pods of white, massive quartz are present in the migmatite contacts at two or three locations. The largest quartz, pod seen was 2.5 feet. A pegmatite dike $1 \times 10$ feet containing quartz, feldsyar, and biotite was found to be barren of sulfides and radioactivity. The pegmatite dikes reported by the U.S. Geological Survey to the north were not examined.

\section{MINEKAL DF.POSITS}

No mineral deposits or prospects are known to be in the area visited by the author. The iron-stained zone and small cuartz pods near the margins of the intrusive do not appear to contain ore minerals.

Copper and nickel deposits in a mafic intrusive are located near Funter Bay 25 miles to the northwest. $A$ copper prospect is near the coast of Seymour Canal west of Swan Island, 8 miles southeast of the felsic intrusive.

\section{RAUIOMEIKIC: SUAVEY}

Foot traverses with a scintillometer across the intrusive yielded responses from 0.005 to $0.02 \mathrm{mr} / \mathrm{hr}$. The higher readings were obtained over localized zones of pegmatitic granite. General radioactivity was no higher than would normally be expected over acidic rocks.

\section{GEOK:HEMISTRY}

Four stream-sediment samples were coilected from short streams draining the steep walls of a cirque 1/2 mile west of the peak that had heen examined for radioactivity (fig. 8). Aiomic absorption analyses are given in table 3 . The highest values obtained were 65 ppm copper, 25 ppm lead, and 70 ppm zinc. None was anomalous.

\section{CONC:LUSIONS}

No significant radioactivity was detected at the felsic intrusive near King Salmon Bay, and prospecting for uranium there is not encouraged.

TABLE 3.-Atomic Absorption Analyses, King Sulmon Bay Area

\begin{tabular}{cccc}
\hline $\begin{array}{c}\text { Lacation on } \\
\text { Figure B }\end{array}$ & $\begin{array}{c}\text { Coppor } \\
\text { ppm }\end{array}$ & $\begin{array}{c}\text { Lead } \\
\text { ppm }\end{array}$ & $\begin{array}{c}\text { Zine } \\
\text { ppm }\end{array}$ \\
\hline 1 & 65 & 20 & 55 \\
2 & 60 & 25 & 55 \\
3 & 55 & 25 & 70 \\
4 & 55 & 15 & 70 \\
\hline
\end{tabular}

\section{TRACY ARM AREA, CHICHAGOF ISLAND}

William Huff (written communication, 1970) repurted that while using an airborne scintillometer be encountered a radiometric anomaly on the east side of the eritrance to Tracy Arm. 'The location was estimated by him to be approximately $57^{\circ} 50^{\prime} \mathrm{N}$, $133^{\circ} 33^{\prime} \mathrm{W}$ at an elevation of about 1,500 feet. This is in the Sumdum D-5 quadrangle approximatcly 50 miles southeast of Juneau (fig. 1).

The area is occupied by strongly foliated, northwest-trending schists and phyllites, and is near the western margin of the Coast Range batholith. The extensive Sumdum copper-7ine prospect is located 4 miles snutheast at an elevation of 4,000 feet on both sides of and beneath the Sumdum Glacier (MacKevett and Blake, 1964). Several prospects containing copper, lead, zinc, and gold are on Tracy and Endicolt Arms (Gault and Fellows, 1953; Herreid, 1962; Race, 1962).

The author visited the area for 1 day but never reached the location where the radinactive anomaly was believed to bc. A font iraverse was made from the east shore of 'lracy Arm, near its mouth, to an elevation of 1,000 feet. Scintillometer readings on the schist were between 0.005 and $0.01 \mathrm{mr} / \mathrm{hr}$. It is possible that the radioactive anomaly reportedly detected from the air was due to outcrops of granodiorite containing considerably higher radioactivity than the surrounding schist. Dioritic boulders contain much visible disseminated pyrite and magnetite. No geochemical samples were taken. 
$134^{\circ} 20^{\prime}$

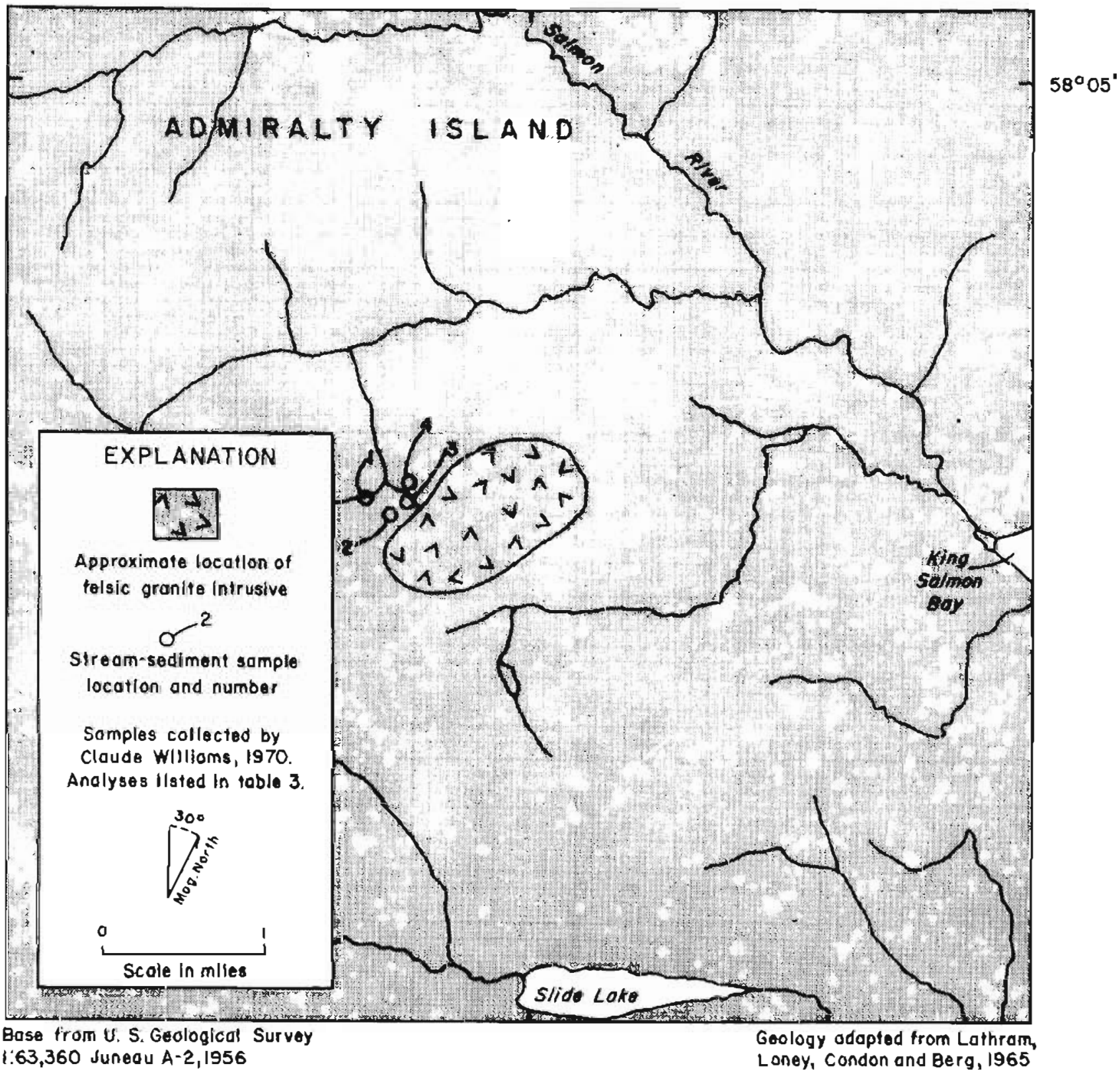

Figure 8 Locations or granite intrusive and stream-sediment samples, King Salmon Bay area, Arimiralty Island (fig. 1, area 2) 


\section{TRAP BAY AREA, CHICHAGOF ISLAND}

\section{LOCATION AND ACCESS}

Trap Bay is an indentation on the south coast of Tenakee Inlet, Chichagof Island, about three miles from Chatham Strait. The area visited is near the junction of the Sitka C-3, C-4, B-3, and B-4 quadrangles, 23 miles northwest of the village of Angoon. The area can be reached by boat or float plane. The Trap Bay locality was visited to examine a radioactive anomaly defected from the air while flying the Kook Lake area with a scintillometer.

\section{GEOLOGY}

The geology of the Trap Bay region has been mapped by Loney, Berg, Pomeroy and Brew (1983). Bedrock along the coast on the east side of the bay is Silurian(?) and Devonian(?) graywacke and argillite. These rocks are overlain by a thick unit of pebble to cobble conglomerate on the ridge east of Trap Bay. A stock of granodiorite crops out on the west side of Trap Bay. The east side of the stock along the valley at the head of Trap Bay and on the west side of the bay is bordered by a narrow zone of homfels. Devonian limestone forms conspicuous bluffs on the north side of Tenakee Inlet opposite Trap Bay and forms a northwest-trending belt west of Trap Bay.

\section{MINERAL DEPOSITS}

A nickel-copper prospect known as the Big Ledge claim is located on the north side of Tenakee Inlet, 4-1/ 2 miles north of the head of Trap Bay (fig. 9). This deposit was described by Buddington (1925, p. 107 . 108). A basic dike 20 feet thick intruding conglomerate contains disseminated pyrrhotite, chalcopyrite, pentlandite, and a little sphalerite and pyrite.

Another prospect, the Three J claim, also on the north side of Tenakee Inlet, is aboul 3-1/2 miles northwest of Trap Bay (fig. 9). The claim covers a copper-molybdenum prospect consisting of veinlets and dikes which contain chalcopyrite and traces of molybdenum, nickel, zinc, and chromium (Berg and Cobb, 1967, p. 145, 146). Neither of the above claims was visited.

On the west side of Trap Bay near its head a shear zone in granodiorite contains considerable iron oxide and trace amounts of copper, cobalt, and zinc. Minor anomalous radiometric responses were noted.

\section{RADIOMETRIC SURVEY}

Foot traverses with a scintillometer along the shores of Trap Bay. Tenakee Inlet, and up a short stream draining into Trap Bay showed that coarse conglomerate on the ridge south of Tenakee Inlet produces an abnormally high radioactive back ground of 0.015 to $0.0025 \mathrm{mr} / \mathrm{hr}$. Argillite and limestone bedrock in the area produced less than 0.010 $\mathrm{mr} / \mathrm{hr}$. The strongest radioactivity, $0.040 \mathrm{mr} / \mathrm{hr}$, was found in crushed material containing iron oxides in the sheared zone cuting granodiorite at the head of Trap Bay. No radioactive minerals could be isolated and the radioactivity was limited to areas a few inches across on fracture surfaces.

\section{GEOCHEMISTRY}

Only two geochemical samples were collected at Trap Bay. These were from separate streams draining into the east side of the bay (fig. 9). Atomic absorption analyses are given in table 4 . The highest values ware: copper $80 \mathrm{ppm}$, lead $35 \mathrm{ppm}$, and zinc $160 \mathrm{ppm}$.

TABLE 4.-Atomic Absorption Analyses, Trap Bay Area

\begin{tabular}{ccccc}
\hline $\begin{array}{c}\text { Field } \\
\text { Figure } 8\end{array}$ & $\begin{array}{c}\text { Sample } \\
\text { Number }\end{array}$ & $\begin{array}{c}\text { Copper } \\
\text { Ppm }\end{array}$ & $\begin{array}{c}\text { Lead } \\
\text { ppm }\end{array}$ & $\begin{array}{c}\text { Zine } \\
\text { ppm }\end{array}$ \\
\hline 1 & E31 & 35 & 30 & 180 \\
2 & E145 & 80 & 35 & 40 \\
& & & & \\
\hline
\end{tabular}

The zinc value for sample location No. 1 is about $50 \%$ higher than amounts usually considered a high normal, but the importance of a single analysis is uncertain. The stream from which it was taken crosses conglomerate over most of its course, but cuts argillite below an elevation of 100 feet.

\section{CONCLUSION}

The anomaly detected at Trap Bay from the air apparently is due to the relatively high radinactivity of coarse conglomerate on the hill east of the bay. The 
GEOLOGIC REPORT 44

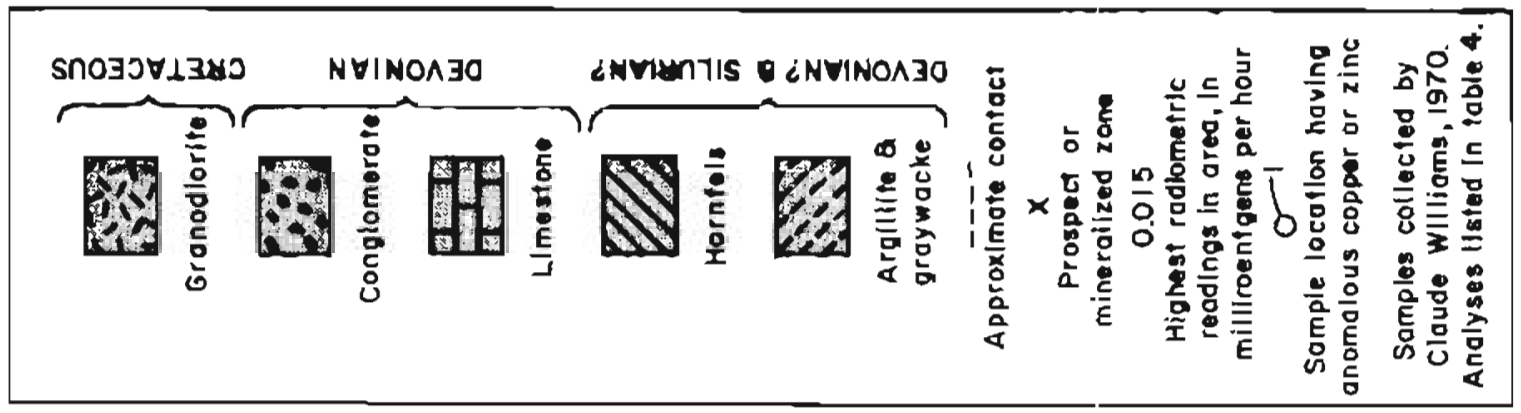
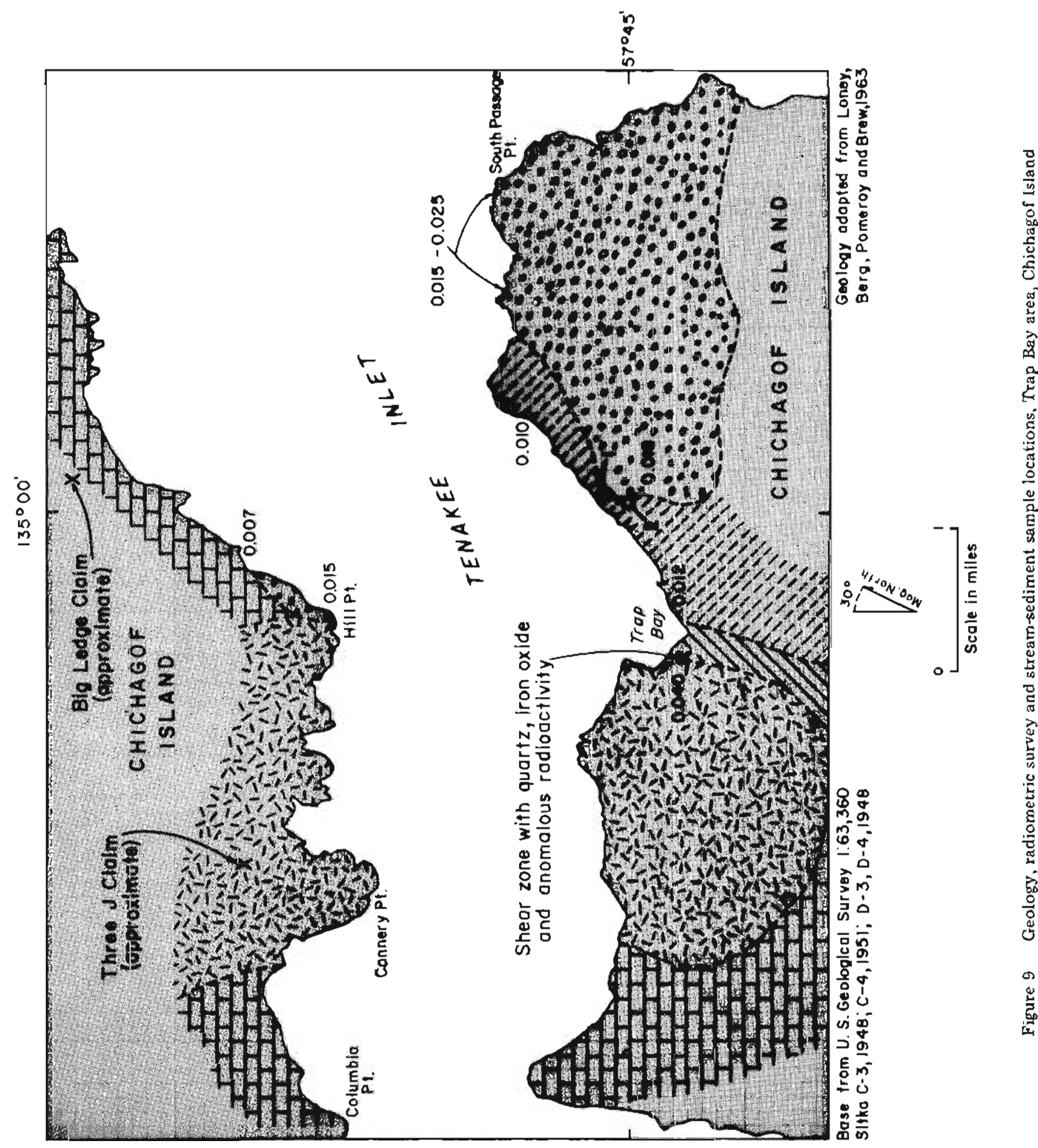
source of the radioactivity is probably the felsic igneous debris so abundant in the conglomerate. The radioactivity at the shear zone near the head of the bay is believed to be due to a trace of uranium or thorium, but it was not in sufficient quentity to encourage prospecting for these elements.

\section{KOOK LAKE AREA, CHICHAGOF ISLAND}

\section{L,OCA'TION AND ACCESS}

Kook Lake is located on the eastern side of Chichagof Island one mile inland from the head of Basket Bay. It is in the Sitka C-3 and C-4 quadrangles, about 45 miles southwest of Juneau. Float plane is the most practical means of reaching the lake. A U.S. Forest Service cabin is maintained near a good beach at the west end of the lake. "'he village of Tenakee on T'enakee Inlet lies approximately II miles to the northwest. The terrain consists of steep mountains which rise abruptly to altitudes of 2,500 feet within 1$1 / 2$ miles of the lake.

\section{HISTOHY}

Most of the mining activity on Chichagof Island has been along the westem edge of the island, especially in the old Chichagof minirg district. Prospects on the eastern side are $\mathrm{few}$, but some have been located 6 to 8 miles north of Konk Lake along T'enakee Inlet. A hot spring at 'Tenakee has been a health resort since the late 1800's. The Kook Lake area was chosen for examination because a sodalite syenite and a nepheline syenite mapped by Loney, Berg, Pomeroy, and Brew (1963) were considered to be favorable rock types for radioactive minerals.

\section{GEOLOGY}

The geology of the Kook Lake area is shown on a reconnaissance geologic map of Chichagof Island (fig. 10) compiled by Loney, Berg. Pomeroy and Brew (1963). A report on the ages of the plutonic rocks was prepared by Lanphere, Loney, and Brew (1985). The eastern third of Kook Lake lies in the northwesttrending belt of Devonian conglomerate, argillite and limestorie. The limestone forms conspicuous white bluffs at the northeast end of the lake. Coarse conglomerate is present between limestone outcrops on the southeast side. Sodalite syenite and nepheline syenite of early Paleozoic age border the westem part of the lake. Several kinds of Paleozoic granite occupy the area west of the Devonian sediments between Peril Strait south of Kook Lake and Tenakee Inlet to the north.

\section{MINERAL DEPOSITS}

Mineral deposits or prospects are not known in the immediate vicinity of Kook Lake. Prospects are present near the entrance to Tenakee Inlet where minor quantities of copper, lead, zinc, nickel, molybdenum, and chromium have been reported from mafic and felsic dikes. Along a strenm entering the southeast end of Kook Lake the author found considerable pyrite in small felsic intrusives in limestone. Pyrite was also found in pods up to 2 inches thick with much iron oxide at 600 feet elevation along a large stream draining a cirque south of the ridge south of Kook Lake. One 10-inch piece of float assayed $0.012 \mathrm{oz} / \mathrm{T}$ gold, $0.014 \mathrm{oz} / \mathrm{T}$ silver, and $0.004 \%$ copper. A sample of iron-stained material with an abundance of pyrite from a zone between geochemical sample locations 3 and 4 (fig. 11) yielded $10 \mathrm{ppm}$ uranium, approximately twrice the average uranium content of acid agneous rocks. The sample also yielded a trace of gold.

\section{RADIOMFTRIC; SURVEY}

Foot traverses with a scintillometer were made along streams south of Kook Lake (fig. II). The radiometric background was between 0.005 and 0.010 $\mathrm{mr} / \mathrm{hr}$. A response up to $0.050 \mathrm{mr} / \mathrm{hr}$ was encountered at an elevation of 500 feet on the south side of Kook Lake where fractures cut basic dikes. Outcrops of syenite (?) in this area gave readirigs up to $0.020 \mathrm{mr} / \mathrm{hr}$.

Another low-grade anomaly of $0.030 \mathrm{mr} / \mathrm{hr}$ was found at an elevation of 450 feet at geochemical sample location 36 near the southeast end of the lake. In contrast, linestone and conglomerate beds in that area produced only $0.005 \mathrm{mr} / \mathrm{hr}$.

A one-hour flight in a light plane with a scintillometer probe tied outside the cabin was made over the east side of Chichagof Island from Tenakee Inlet south to Kitkoh Bay in an attempt to locate any radiometric anomalies present in the various intrusives in the area. The terrain flown was very rugged and flying conditions were poor. There was little control as far as maintaining constant speeds or distance above ground, and radiometric readings 


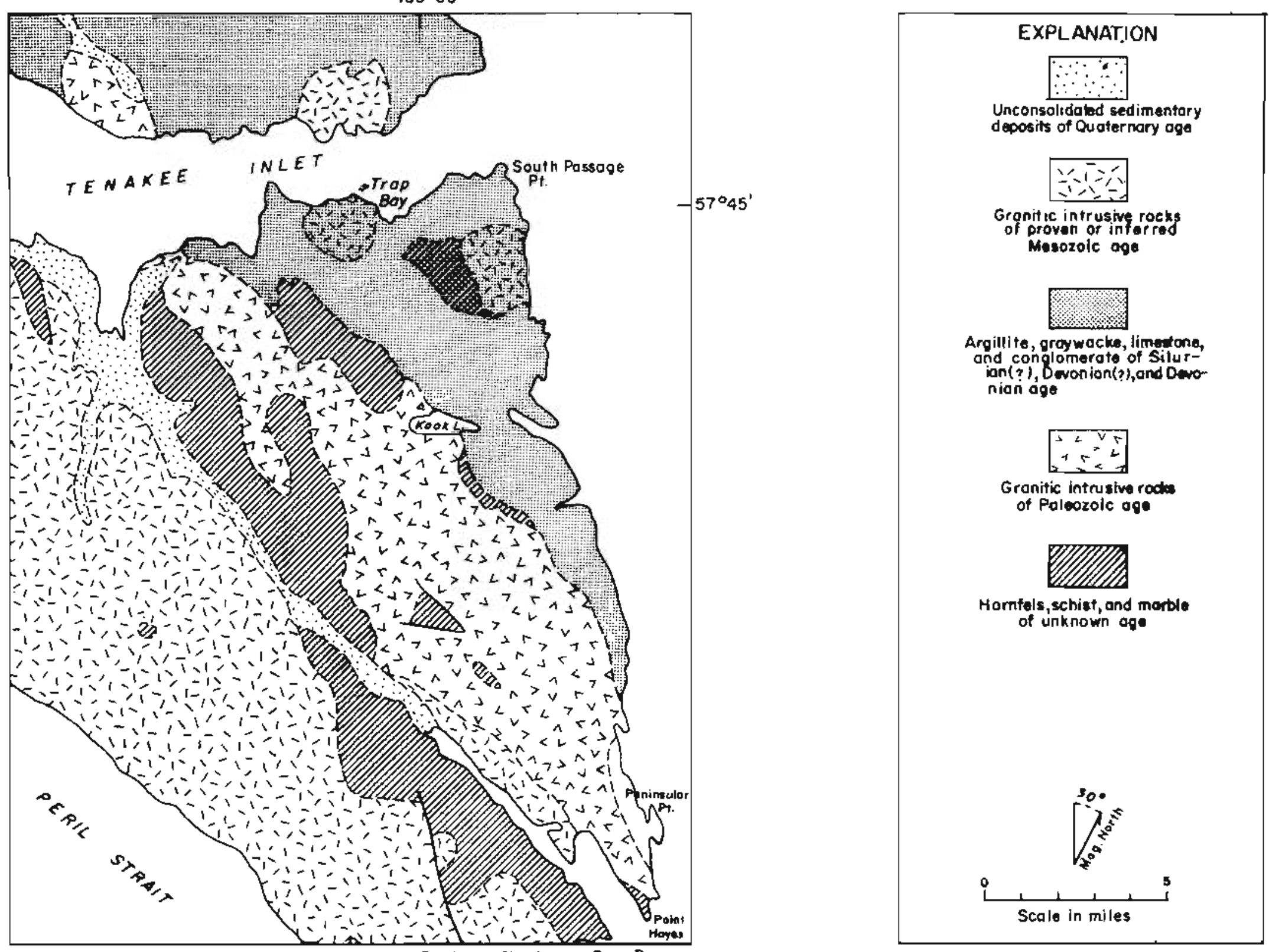

Figure 10 Generalized geologic map, Kopk Lake area, Southeastern Alaska (fig. 1, area 5 ) 
therefore were rather haphazard. The pilot attempted to contour-fly a number of the mountain peaks at distances between 300 to 800 feet. During most of the flight the responses were under 100 counts per minute. The highest readings, 180 counts per minute were obtained over a 3,000-foot mountain on the south side of an unnamed lake two miles south of Basket Lake, and over the ridge just east of Trap Bay near the entrance to Tenakee Inlet. Only the anomaly at Trap Bay was checked on the ground.

\section{GEOCHEMISTRY}

Stream-sediment samples were cullected at 44 localities in the Kook Lake area (fig. 11). Atomic absorption analyses are given in table 5 . Histograms appear in figure 12, Slightly anomalous values were: copper, 80 and $90 \mathrm{ppm}$; lead, $55,75,85$, and $225 \mathrm{ppm}$; and zinc, 210,210, 220,230,250,275, and $290 \mathrm{ppm}$.

Seven zinc values considered anomalous were from sample locations $16,25,26,27,28,30$, and 38 . Five of these were from the stream south of the west end of the lake between elevations of 500 and 1,000 feet. The bedrock is granite. One sample is from near the head of a stream on the south side of the lake, and one is from a small stream on the north side. The highest lead value, $225 \mathrm{ppm}$, was from the area at the southeast end of the lake.

TABLE 5.-Atomic Absorption Analyses, Kook Lake Area (anomalous values underlined)

\begin{tabular}{|c|c|c|c|c|}
\hline $\begin{array}{l}\text { Location on } \\
\text { Figure } 11\end{array}$ & $\begin{array}{c}\text { Field } \\
\text { Sample } \\
\text { Number }\end{array}$ & $\begin{array}{c}\text { Copper } \\
\text { Ppm }\end{array}$ & $\begin{array}{l}\text { Lead } \\
\text { ppm }\end{array}$ & $\begin{array}{l}\text { Zinc } \\
\text { ppm }\end{array}$ \\
\hline 1 & $P 44$ & 30 & 15 & 80 \\
\hline 2 & P45 & 40 & 20 & 100 \\
\hline 3 & $\mathrm{P}_{46}$ & 20 & 25 & 130 \\
\hline 4 & 447 & 30 & 35 & 115 \\
\hline 5 & P48 & 20 & 25 & 95 \\
\hline$\theta$ & P49 & 30 & 25 & 110 \\
\hline 7 & P50 & 35 & 30 & 170 \\
\hline 8 & P5! & 30 & 25 & 110 \\
\hline 9 & P52 & 25 & 20 & 115 \\
\hline 10 & P53 & 20 & 80 & 110 \\
\hline 1$\}$ & P5A & 20 & 20 & 100 \\
\hline 12 & $P 84$ & 25 & 20 & 75 \\
\hline 13 & P85 & 20 & 20 & 75 \\
\hline 14 & $P 83$ & 15 & 20 & 80 \\
\hline 15 & $P \otimes B$ & 15 & 15 & Q5 \\
\hline
\end{tabular}

TABI.E 5. Atomic Absorption Analyses Kook Lake Area -Continued

\begin{tabular}{|c|c|c|c|c|}
\hline $\begin{array}{l}\text { Location on } \\
\text { Figure } 11\end{array}$ & $\begin{array}{l}\text { Field } \\
\text { Sumple } \\
\text { Number }\end{array}$ & $\begin{array}{l}\text { Copper } \\
\text { ppm }\end{array}$ & $\begin{array}{l}\text { Lead } \\
\text { ppm }\end{array}$ & $\begin{array}{l}\text { Zine } \\
\text { ppm }\end{array}$ \\
\hline 16 & $\mathrm{P} 62$ & 25 & 25 & $\underline{275}$ \\
\hline 17 & $P B 1$ & 20 & 15 & 90 \\
\hline 18 & $\mathrm{P} 60$ & 60 & I5 & 70 \\
\hline 19 & P59 & 65 & 20 & 90 \\
\hline 20 & P57 & 60 & 20 & 75 \\
\hline 21 & PSH & $B 0$ & 20 & 75 \\
\hline 22 & P43 & 10 & 10 & 50 \\
\hline 23 & P42 & 40 & 35 & 190 \\
\hline 24 & P4l & 40 & 35 & 180 \\
\hline 25 & $P 40$ & 40 & 30 & 290 \\
\hline $2 \theta$ & P39 & 45 & 35 & 210 \\
\hline 27 & P38 & 40 & 45 & 210 \\
\hline 28 & P37 & 35 & 55 & 250 \\
\hline $2 \theta$ & $\mathrm{P} 33$ & 10 & 85 & $\overline{190}$ \\
\hline 30 & $P 35$ & 20 & 75 & $\underline{220}$ \\
\hline 31 & ElB & 1.5 & 15 & 85 \\
\hline 32 & El4 & 20 & 20 & 100 \\
\hline 33 & E15 & 20 & .15 & 95 \\
\hline 34 & Elo & 15 & 15 & 85 \\
\hline 35 & \pm 8 & 35 & 20 & 45 \\
\hline 36 & $\mathrm{~F}, 10$ & 40 & 20 & 40 \\
\hline 37 & E12 & 25 & 15 & 30 \\
\hline $.3 B$ & Ell & 55 & 25 & 230 \\
\hline 38 & E5B & 95 & 35 & 130 \\
\hline 40 & $P 58$ & 45 & 15 & 95 \\
\hline 41 & P55 & 45 & 15 & 100 \\
\hline 42 & E8 & 55 & 40 & 150 \\
\hline 43 & $\mathrm{E} \theta$ & 55 & 225 & 140 \\
\hline 44 & E7 & 80 & 45 & 100 \\
\hline
\end{tabular}

The radiometric responses encountered near Kook Lake did not indicate uranium deposits. However, above average radioactivity was generally found in the country rocks. This investigation was very limited, but the intrusives occupying a much larger portion of the east side of Chichagof Island appear to offer possibilities. The flight over these was inadequate, and more controlled aerial surveys with the proper equipment might produce more positive results.

A sample of light-colored granitic rock from $1 / 2$ mile south of the west end of Kook Lake was analyzed for uranium and showed $10 \mathrm{ppm} e U$, which is twice 


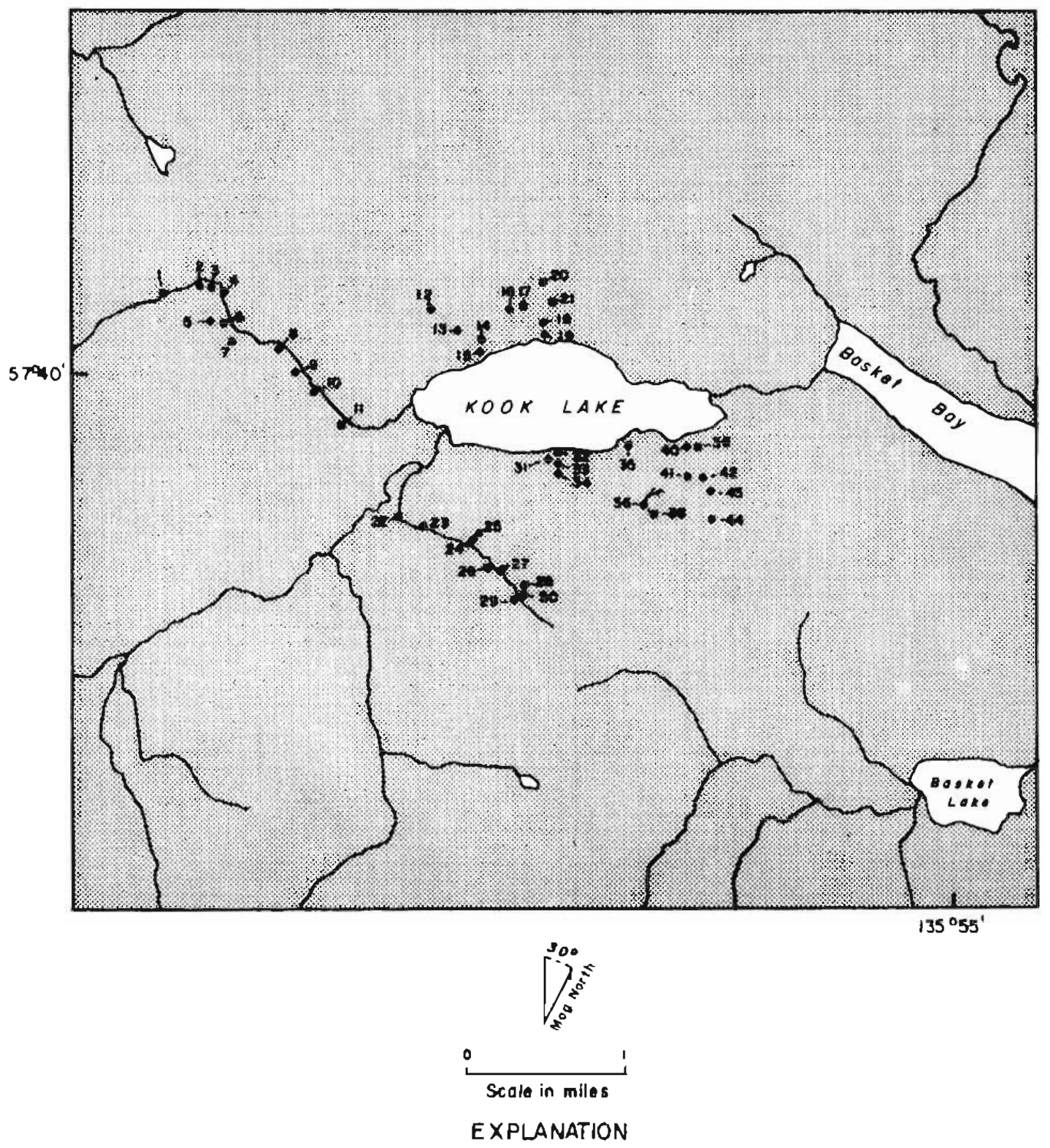

- I-44 Stream sediment sample location and number Analyses are listed in tablo 5

Figure 11 Strenm-sedimeat sample locations, Kook Lake area, Chichagof Istand (area shown on figure 10) 


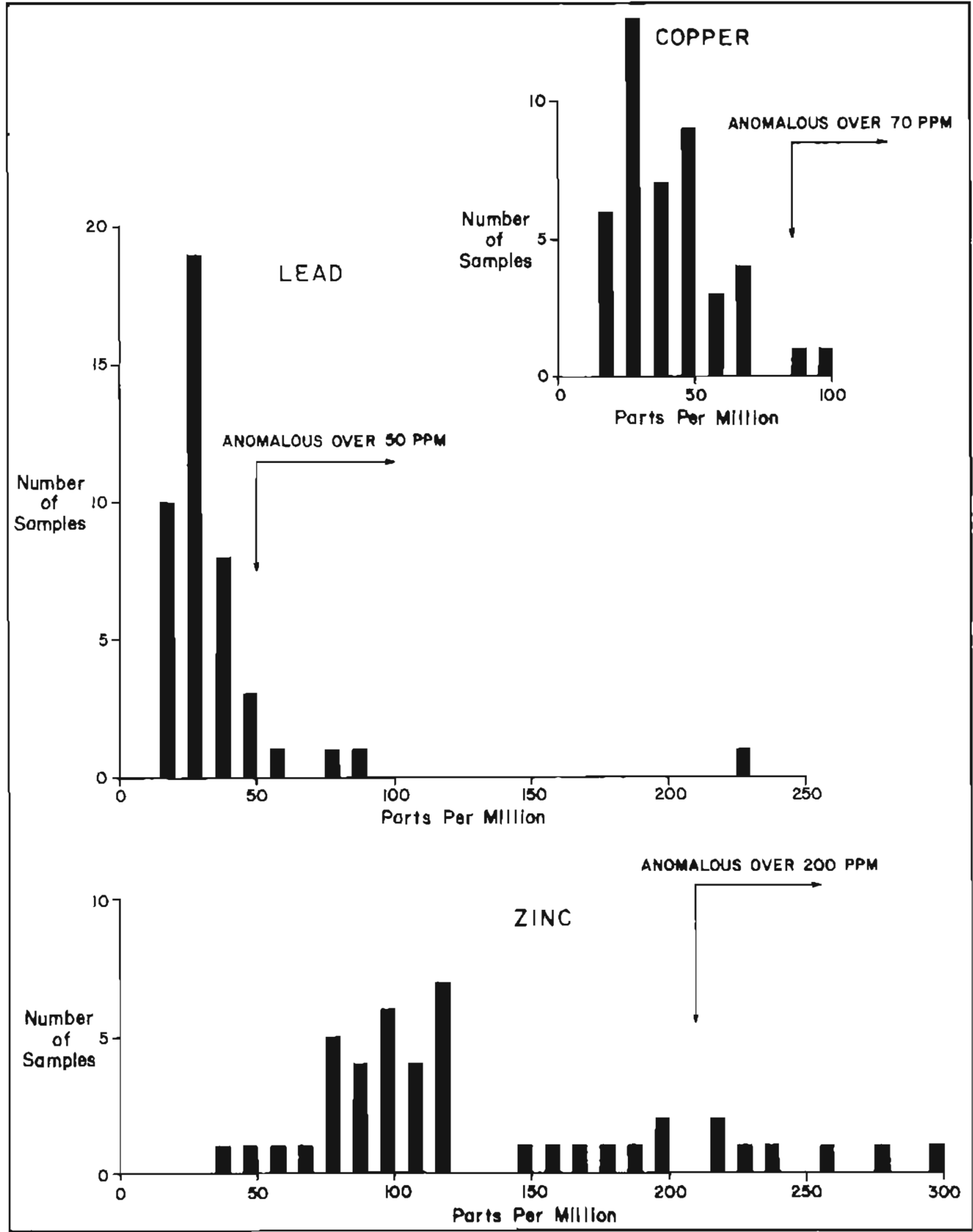

Figure 12 Frequency distribution histogram baned on atomic absorption aralyses for copper, lead, and zinc, Kook Lake area 
the avcrage for acid igneous rocks. Anomalous values for lead and zinc from stream-sediment samples suggest that the area could contain concentrations of base metals.

\section{KOOTZNAHOO INLET-MITCHELL BAY AREA ADMIRALTY ISLAND}

\section{LOCATION AND ACCESS}

Kootznahoo inlet and Mitchell Bay are in an area of low relief on the west side of Admiralty Island near its midpoint in the Sitka B-2 and C-2 quadrangles. Angoon, the only permanently inhabited village on the island, is near the entrance to Kootznahoo Inlet about 43 miles northwest of Sitka. Angoon is served by scheduled flights from Juneau and Sitka. Landings by chartered foat planes may be made anywhere in Mitchell Bay, Numerous narrow waterways make it possible to examine well-exposed Tertiary sandstones along the shores by small boat. However, very strong tidal currents in Kootznahoo Inlet and Davis Creck make it advisable for small craft to travel these narrows during slack tide.

\section{HISTORY}

No metallic minèral deposits have been discovered in the area. Exploration has been restricted to the scarch for coal, which has been found in the lower part of the Tertiary sequence. The first coal sample reported from Mitchell Bay was submitted to the Navy Department in 1896. The coal prospects have been described by Wright (1906, p. 153, 154), and Dall (1896, p. 776-783). These apparently were all abandoned by the time of Wright's investigation, having been found unsuitable for use by the Navy. Ruins of the most extensive operation are still evident on the south side of Kanalku Bay (fig. 13). Brief examinations of the sediments in the area, possibly for wanium, are rumored to have been made in recent years by petroleum company geologists.

\section{GEOLOGY}

The following summary of the geology of the Kootznahoo-Mitchell Bay area is taken from Buddington and Chapin (1929, p. 261-263), Lathram, Pomeroy, Berg, and Loney (1965), and Smith 1939). Approximately 38 square miles are occupied by nonmarine sediments belonging to the Kootznahoo Formation, which is present in the low areas around Kootznahoo Inlet, Mitchell Bay, Kanalku Bay, and Davis Creek, and on the low hills north of Kootznahoo Inlet. Fossil flora indicate the age of the formation to be Paleocene through Miocene. Its total thickness is believed to be about 5,000 feet. Its lithology is described as predominantly pebble to cobble conglomerate, fine-grained to arkosic sandstone, lithic sandstone, calcareous siltstone, calcareous shale, lignite and subbituminous coal. ('arbonized plant material is common.

The Tertiary sediments overlie, with angular unconformity, Devonian schist and phyllite and undifferentiated Mesozic metamorphic rocks. Conspicuous lineation of channels and topographic features are cvident on topographic maps and aerial photos. Some of the channels are apparently occupied by large fauls. Tilting of the beds is thought to be due mostly to faulting and central-basin subsidence rather than to folding. Dips averuge about $30^{\circ}$, but vary from a few degrees to $45^{\circ}$.

The coarseness, poor sorting, and grain angularity of much of the Kootznahoo Formation indicate deposition near its source (fig. 14). Some beds of conglomerate around Mitchell Bay contain boulders up to 12 inches in diameter. These rocks represent consolidated alluvial fans formed in an intermontane basin. Fine-grained material with silt and coal near the middle and southem part of the basin indicate ancient swamps. $\Lambda$ n apparent northward increase in coarseness of the sediments ard crossbedding, observed during the Division's uranium investigation, suggest that their source was north of the basin.

Intrusive quartz diorite and grunodiorite form a batholith occupying approximately 150 square miles beginning about 5 miles north of Mitchell Bay (north of the map area). Smaller intrusives are present at the northwest end and south side of Mitchell Bay.

\section{MINERAL DEPOSI'TS}

The only material of economic significance so far discovered in the area is coal. The deposits were rather well prospected in early days and are of no economic interest at the present.

\section{RADIOMETRIC SURVEY}

No significant radioactivity was encountered in the Kootznahoo Inlet-Mitchell Bay area. The highest scintillometer reading encountered was $0.02 \mathrm{mr} / \mathrm{hr}$ or 


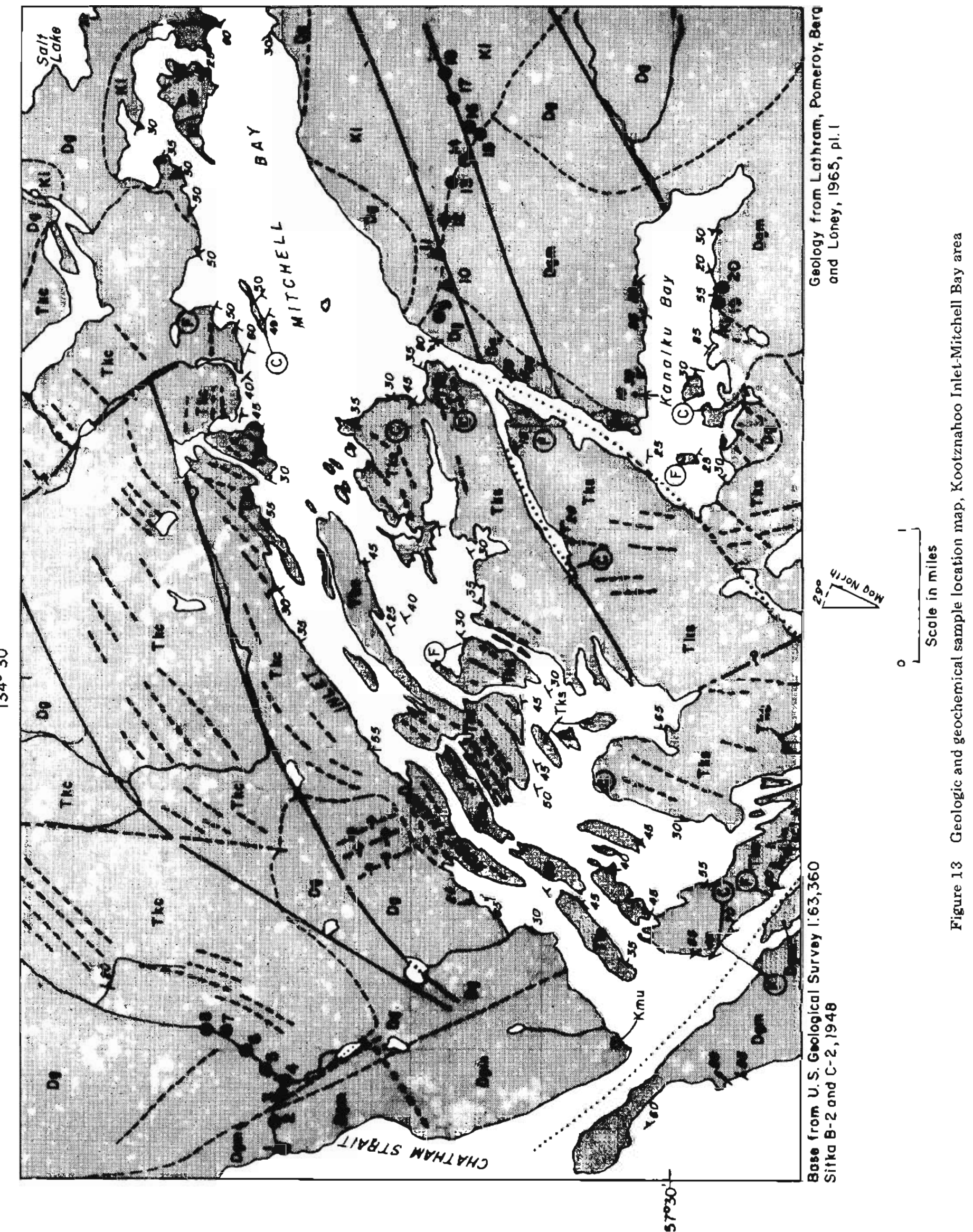


GEOLOGIC REPORT 44

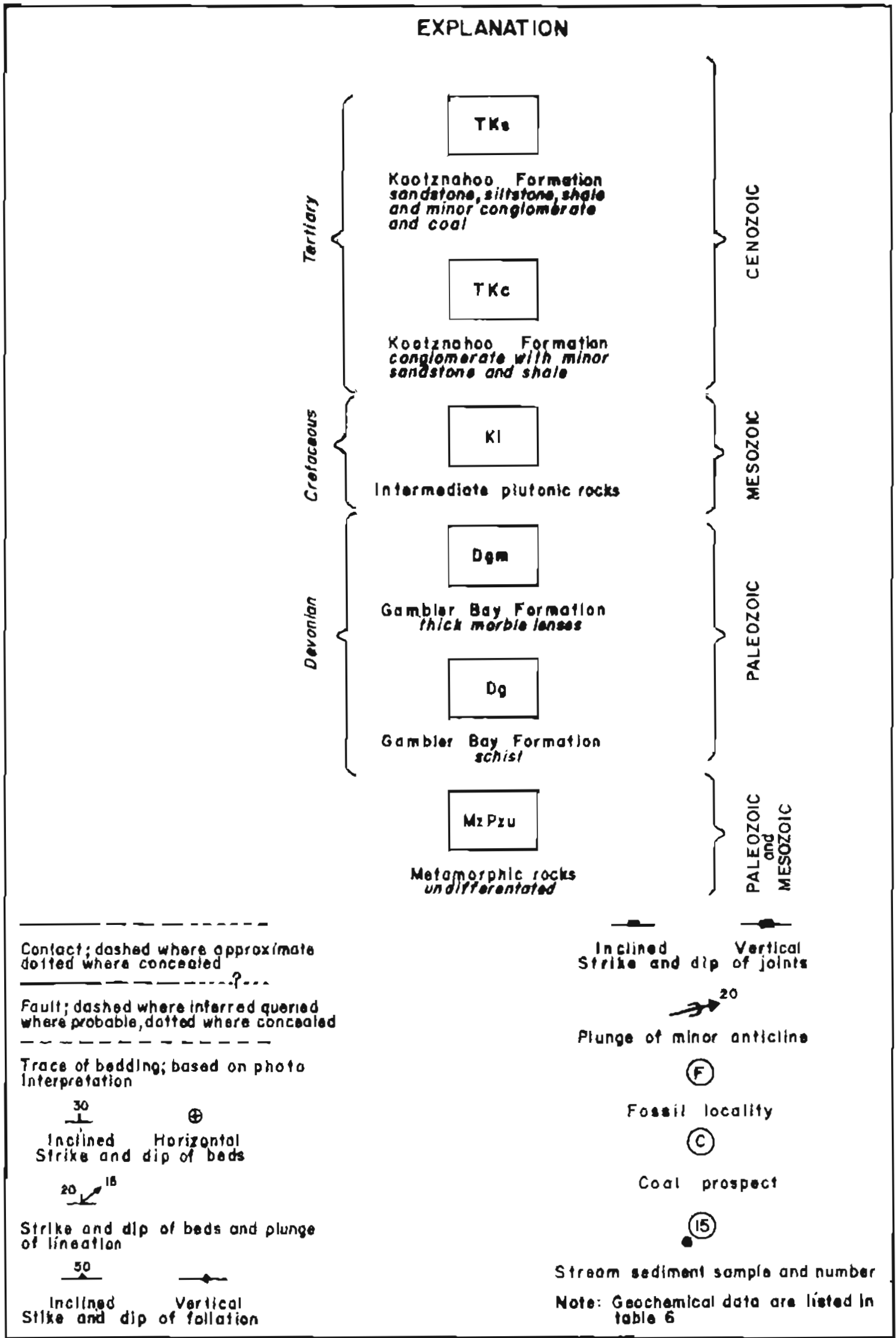



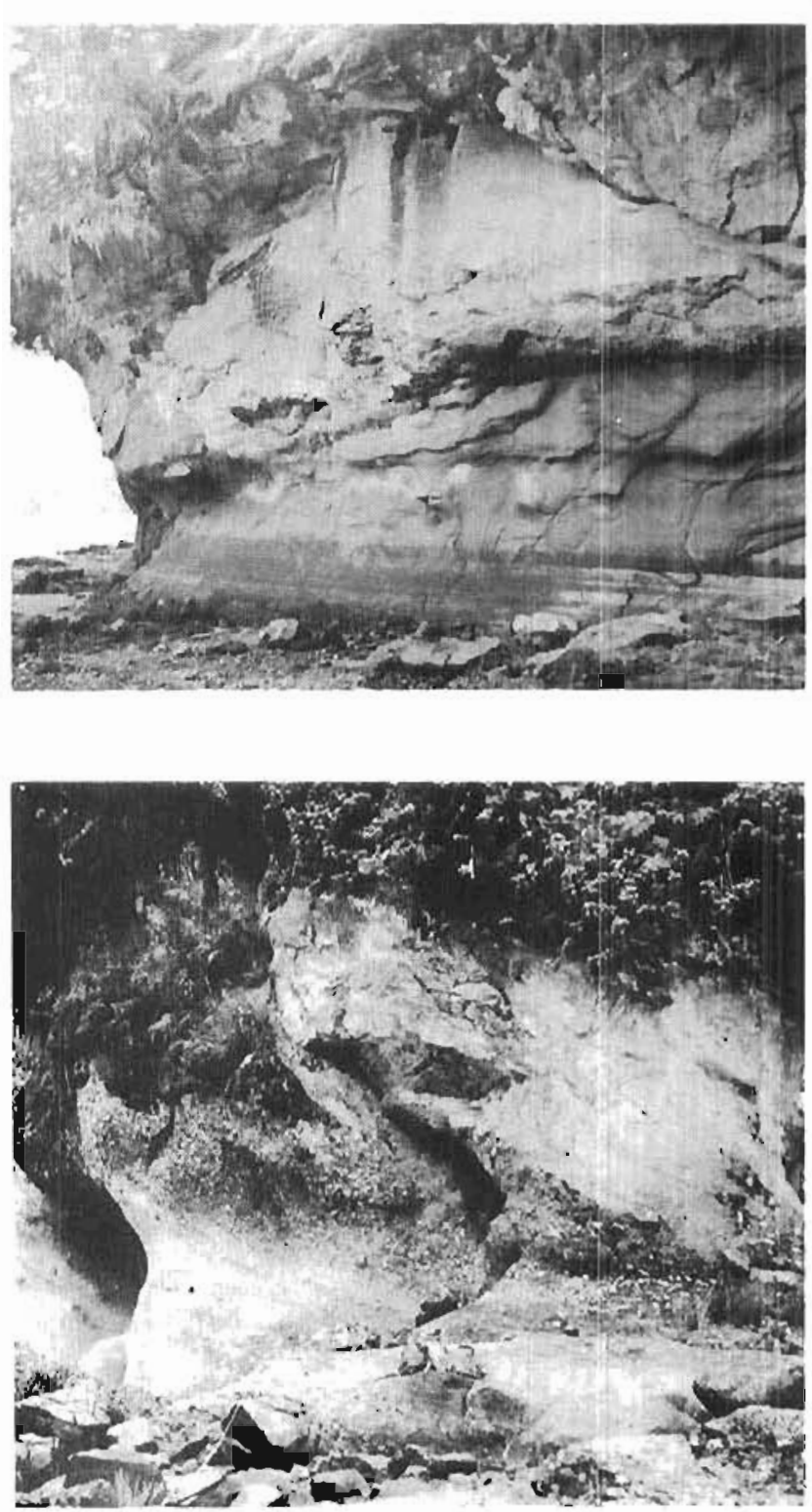

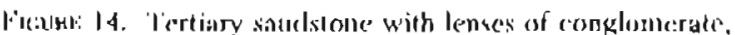

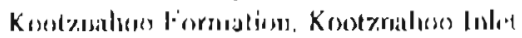

about threc times the background, which was found in an oxidized rone cutting schist approximately 100 yards from shore up a strean entering Mitcliell Bay just north of the mouth of Davis Crerk, on the east sidic.

About 3 miles north of the mouth of Kootznalsoo Inlet a large stream enters Chatham Strait. A foot traverse up this stream was made to examine the T'ertiary rosks present on a 1,500-foot hill one mile from shore A nitximum of $0.015 \mathrm{mr} / \mathrm{hr}$ was found in schist at elevations of 100 and 250 feet. The background was $0.006 \mathrm{mr} / \mathrm{hr}$. Very few sandstone outcrops were observed.

\section{GEOCHEMISTRY}

Twerty stream-sediment samples were collected in the area. Eight were taken in a large stream entering Chatham Strait about 3 miles north of Angoon and in the mouth of Kootznahoo Inlet. Ten samples were taken just south of Mitchell Bay and 2 from Kanalku Bay. Sample locations are shown on figure 13. Atomic absorption analyses are given in table 6 . Histograms are shown in figure 15. The highest values were 45 ppm copper, $15 \mathrm{ppm}$ lead, and $120 \mathrm{ppm}$ zinc. None of these samiples was found to be anomalous.

TABLE 6.-Atomic Absorption Arulyses, Kootznahoo Inlet-Mitchell Bay Area

\begin{tabular}{ccccc}
\hline $\begin{array}{c}\text { Location on } \\
\text { Figure 13 }\end{array}$ & $\begin{array}{c}\text { Field } \\
\text { Semple } \\
\text { Number }\end{array}$ & $\begin{array}{c}\text { Copper } \\
\text { ppm }\end{array}$ & $\begin{array}{c}\text { Lead } \\
\text { Ppm }\end{array}$ & $\begin{array}{r}\text { Zinc } \\
\text { ppm }\end{array}$ \\
\hline 1 & P27 & 30 & 15 & 100 \\
2 & P28 & 30 & 15 & 100 \\
3 & P29 & 15 & 10 & 45 \\
4 & P30 & 25 & 15 & 95 \\
5 & P31 & 25 & 15 & 115 \\
& & & & \\
8 & P32 & 25 & 10 & 90 \\
7 & P33 & 20 & 15 & 55 \\
8 & P34 & 30 & 10 & 85 \\
9 & P23 & 35 & 15 & 70 \\
10 & P22 & 40 & 15 & 80 \\
11 & & & & \\
12 & P21 & 30 & 15 & 75 \\
13 & P20 & 45 & 15 & 85 \\
14 & P19 & 20 & 10 & 50 \\
15 & PIB & 15 & 10 & 45 \\
& P17 & 20 & 10 & 55 \\
18 & & & & \\
17 & P18 & 10 & 15 & 55 \\
18 & P15 & 10 & 15 & 55 \\
19 & P14 & 10 & 15 & 45 \\
20 & 124 & 35 & 15 & 85 \\
& P25 & 30 & 15 & 120 \\
& & & & \\
\hline & & & & \\
\hline
\end{tabular}

Fourteen stream sediment samples were collected around Mitchell Bay and Kanalku Bay by Race and Rose (1967, fig. 1) None of these was anomalous for 
GEOLOGIC REPORT 44

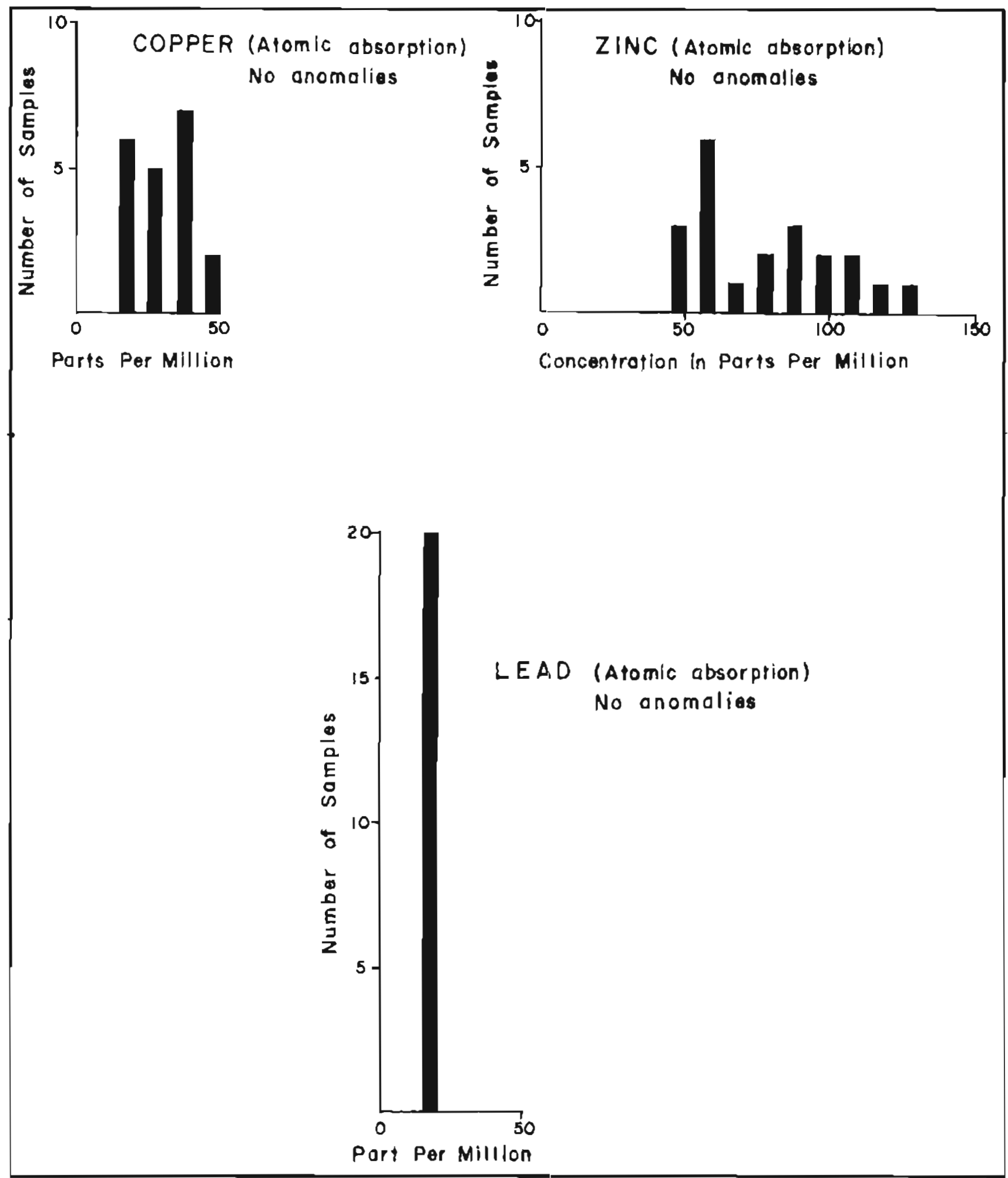

Figure 15 Frequency distribution hislogram based on atomic absorption analyses for coppex, lead, and zinc, Kootzahoo Inlet-Mitchell Bay ares 
copper, lead or zinc. A moderate anomally in zinc was encountered -in two samples from two streams draining Yellow Bear Mountain about 4 miles east of Mitchell Bay.

\section{CONCLUSIONS}

Radiometric readings and mineralogy of the nonmarine Tertiary outcrops in the Kootznahoo InletMitchell Bay area did not suggest the possibility of radioactive deposits. Certain features generally considered to be characteristic of uranium-bearing sandstones such as the presence of pyrite, vanadium, copper, arsenic, good porosity, and alteration or bleaching, were not observed.

\section{BBH URANIUM CLAIM ENDICOTT ARM AREA}

\section{LOCATION AND ACCESS}

The BBH No. 1 uranium claim is near the east shore of a short branch of Endicott Arm 2 miles below the present terminus of North Dawes Glacier. It is about 75 miles southeast of Juneau in the Sumdum C-3 and C-4 quadrangles (fig. 16). The prospect is on a stream draining a sieep slope on the east side of the inlet.

The area can be reached by boat or float plane. Landings along the shoreline are difficult, because the walls of Endicott Arm are steep and there are no beaches. Icebergs from the main Dawes Glacier are usually numerous in the main arm and nnay choke the waterway. However, the shorter arm below North Dawes Glacier is usually free of ice during the summer months.

\section{HISTORY}

The BBH No. 1 claim was staked in 1955. Two samples submitted to the Territorial Assay Office showed $0.03 \%$ and $0.04 \% \mathrm{eU}$, and $0.015 \%$ and $0.032 \% \mathrm{U}$ by fluorimeter. These results led to an examination of the claim by the Territorial Department of Mines (Williams, 1955a). Samples collected by Williams had lower values: $0.01 \%, 0.002 \%, 0.002 \%$, and $0.011 \%$ eU. Apparently no further exploration or development work was done on the property, but William Huff (written commun., 1969) reported that fluorescent uranium minerals are present on a ridge south of Endicott Arm.

\section{GEOLOGY}

The $\mathrm{BBH}$ claim is near the westem margin of the Coast Range batholith. Bedrock at the claim is Cretaceous granodiorite or quartz diorite. The batholith is bounded on the west by a belt of metamorphic rocks and outlying intrusives of upper Paleozoic to Mesozoic age, which contain numerous old claims and prospects. Mapping across this belt north of Juneau (Forbes, 1959) shows a progressive increase in metamorphic grade eastward toward the batholith. Gradational layering of schist and gneiss are present. Forbes showed that the gneiss is a schist which has been transformed by the late injection of $\mathrm{Na}, \mathrm{SiO}_{2}$, and minor K. Herreid (1962, p. 6) found no disruption of minor structures along contacts between gneiss and quartz diorite, indicating a passive introduction of the kgneous rock.

At the Ввн claim, small pegmatite pods and lenses within a medium-gray, medium-grained quartz diorite are radioactive. The quartz diorite there is slightly foliated. Reconnaissance geology of the area is shown in figure 17.

\section{MINERAL DEPOSITS}

Several mines and prospects are located 10 to 25 miles west of the BBH claim. No mines are active, but several prospects are. The better known properties include a zinc-copper lode on Tracy Arm, which was estimated to average $3.2 \%$ zinc, $1.5 \%$ copper, plus a little gold and silver (Berg and Cobb, 1987). Near Sumdum Glacier a copper-zinc lode was discovered in 1958 and explored during 1959. The mineralized zone may extend 2 miles (MacKevett and Blake, 1964). The Sumdum Chief mine on Endicott Arm is said to have produced about $\$ 50,000$ in gold prior to closing in 1904. Underground exploration has been done on silver-and gold-bearing lodes near Point Astley. Near the head of Windham Bay, about 12 miles west of the head of Endicott Arm, a number of placer and lode gold deposits were worked between 1900 and 1937. The lodes are quartz stringers in schist, which contain pyrite, pyrrhotite, galena, sphalerite, arsenopyrite, chalcopyrite, and free gold (Berg and Cobb, 1967, p. -191).

Radioactive pegmatitic zones are exposed at the BBH claim along a steep stream from the shore to an elevation of about 150 feet. They lie within an area approximately 100 to 250 feet (fig. 18). Four small pods or lenses of pegmatite up to 12 feet long roughly parallel cleaveage planes in granodiorite (fig. 19). The radioactive mineral was tentatively identified as uraninite (Williams, 1955a). Country rock at the 


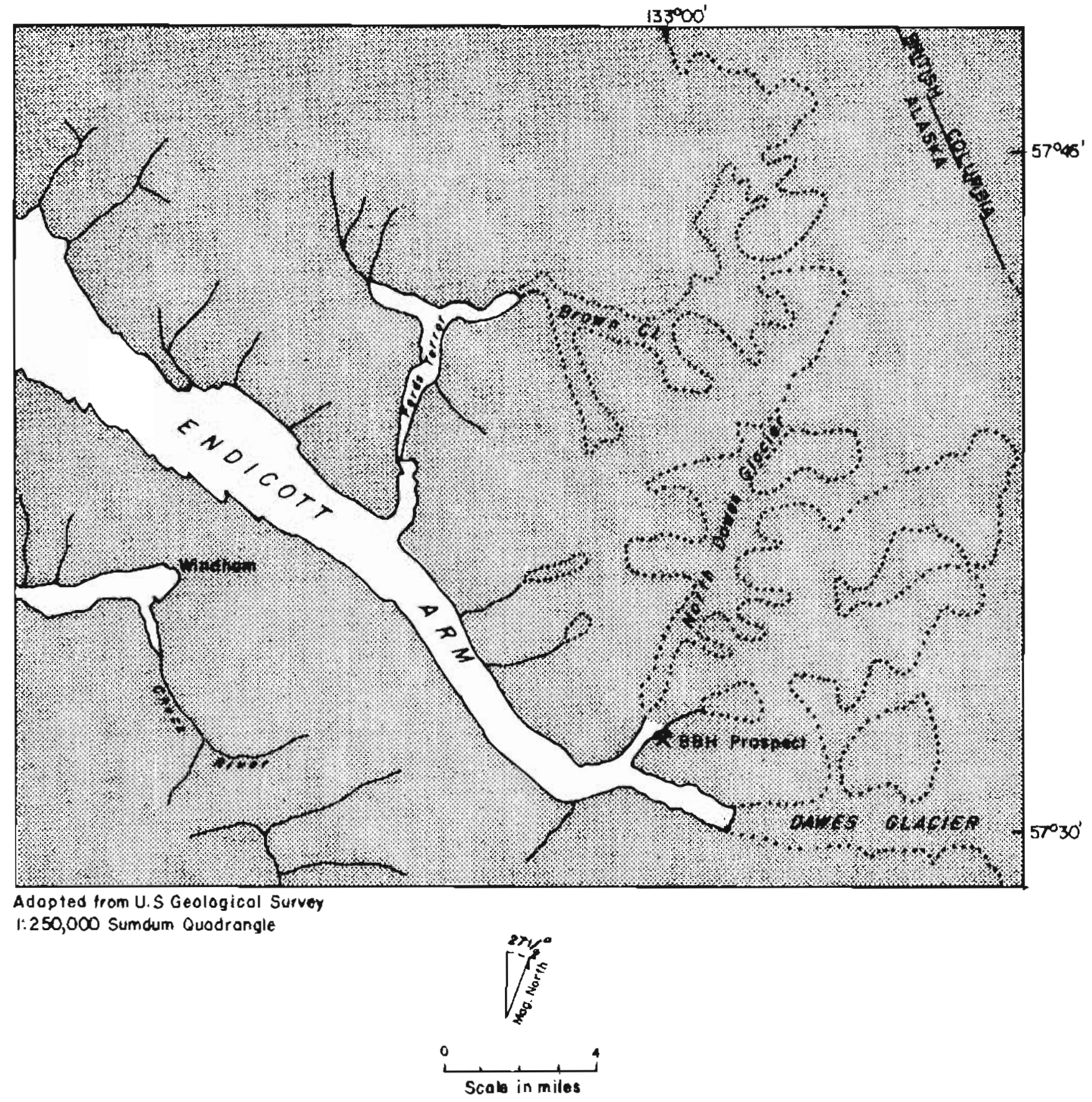

Figure 16 Location of the BBH prospect, Endicott Arm area (fig. 1, area 7) 


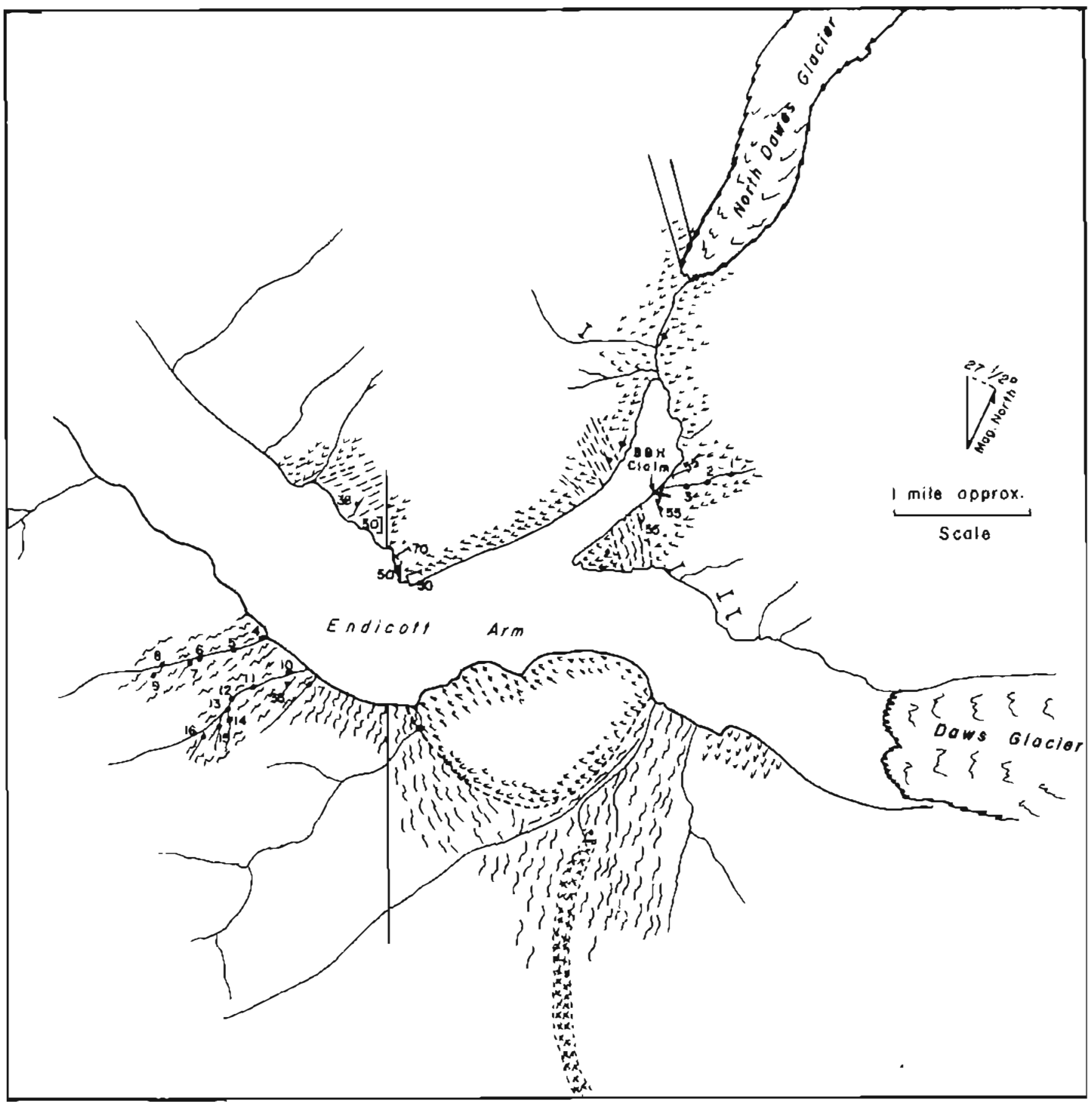

EXPLANATION

Follation

50

Strike and dip of follation in intrusive rocks and schigtosity in schist

ron

Vortical follation

Cleovage

$\sqrt{40}$

strite and dip of cleavage

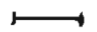

Vertical cleavage

Figure 17 Reconnaissance geologic and stream-sediment sample locations, part of Endicotb. Arm area, Sumdum quad-

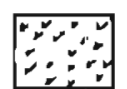

Quertz diorite-granodiorile nonfoliated to strongly foliated $\tilde{\Sigma} \approx \tilde{z}$

Schist with minor phyllite $x \times x \times$
$x \times x \times x$
$x \times x \times$

Poselble dike or sill-mapped from a erial photo

Geology by G.R. Eakins, 1970 rangle 


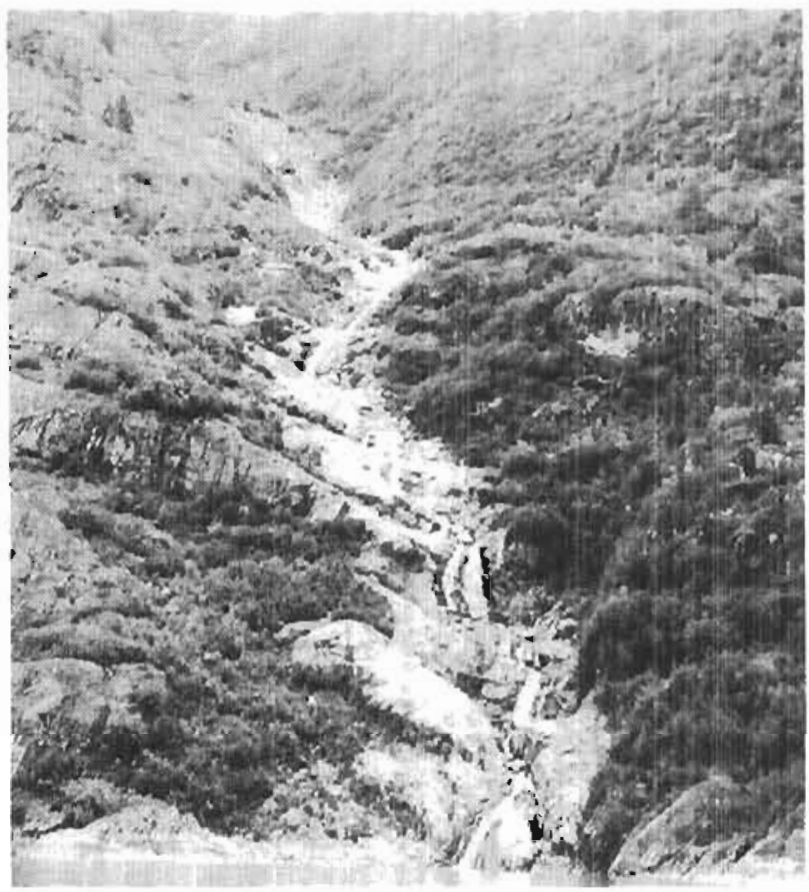

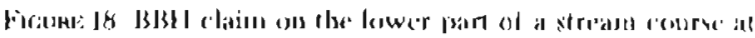
Lindicust $\Lambda$ rst

property normally is il [resh gray granodinrite, but it is partly altered to a brown, softer material. Alteralion zones trend $N 60.70^{\circ} \mathrm{E}$, parallel to cleavenge. Minerals in the pegmatite identifiable in hand sperimens are $K$ feldspar, quart\%, pyrite, and biotite which was found in plates up 10 inches across. Two samples of pegmatite from the BBll claim assayed in 1970 yielded 35 and 45 ppm uranium.

Foot traverses along the shorcs and stream bordering the north branch of Endicott Arm and along the river to the terminus of North Dawes ylacier revealed that small pegmatites similar to those of the BBH claim are fairly common in the area. None of these was more than 30 feel long or 2 feet wide. The largest observed is shown in figure 20 . Most of the pegnatites in the area produced an appreciable radiometric response, but significant alteration and rather large amounts of pyrite were seen only at the BBH property.

A copper-bearing vein at Point Astley near thesouth side of the entrance to Endicott $A$ rm was studied by llouston, Bates, Velikanje and Wedow (1958, 1). 25). Slight radinactivity was reported at one point underground. A 2-foot sample assayed $0.006 \%$ equivalent uranium, but no radioactive minerals w'ere identified.

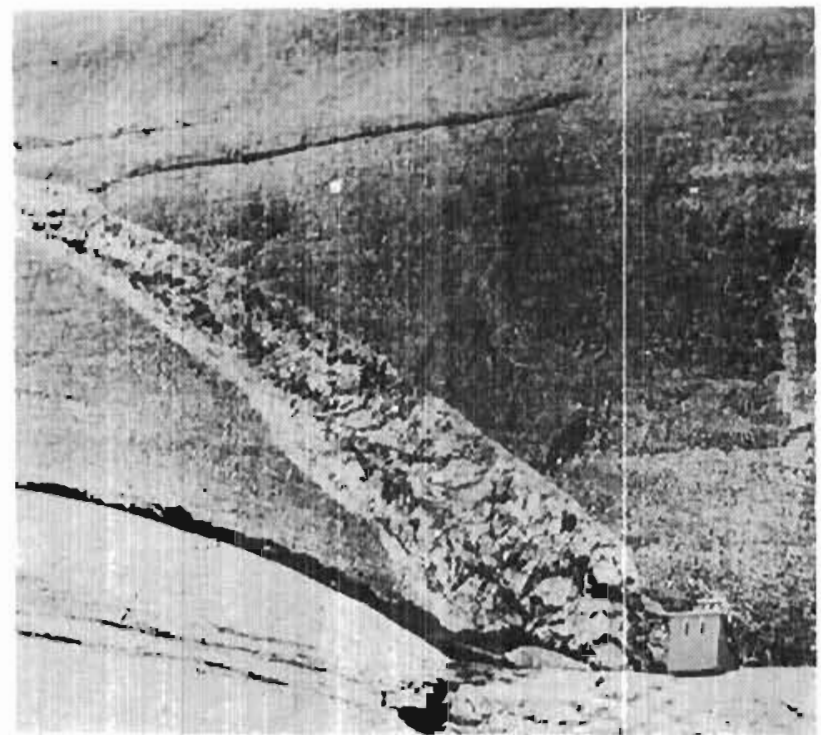

figure 20). l'egmatite lens in dinrill noar trerminus of North

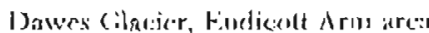

\section{RADIOMEITRI SUHVEYS}

Examination of the BBH claim with a sijintitlometer produced a maximum response of $0.1 \mathrm{rur} / \mathrm{hr}$. which was about ten times the average background of 0.01 $\mathrm{mr} / \mathrm{hr}$ over the granodiorite. Most of the pegmatites on the claim and at other places in the general area yielded around $0.05 \mathrm{mr} / \mathrm{hr}$, but onc pegmatite along the river draining North Dawes Glacier also yave a 0.1 $\mathrm{mr} / \mathrm{h}$ reading at one point. Radioactivity of schist was lower than that of granodiorite, usually less than 0.005 $\mathrm{mr} / \mathrm{hr}$.

\section{CEOCHIMISIRY}

Seventeen stream-sediment sumples were collected at Endicoll Am, Three came from the stream crossing the BBH clain and 14 from threc streams on the south side. Sample locations are shown on figure 17. Atomic absorption analyses are given in table 7. The highest values were 70 ppm copper, 15 ppm lead, and 120 ppm zinc.

These came from sample location 10, rear a zone of highly iron-stained schist. Additional geochemical data from the Sumdum C-4 cjusdrangle were reported by Clark, Brew, Grybeck, and Wehr (1970). 


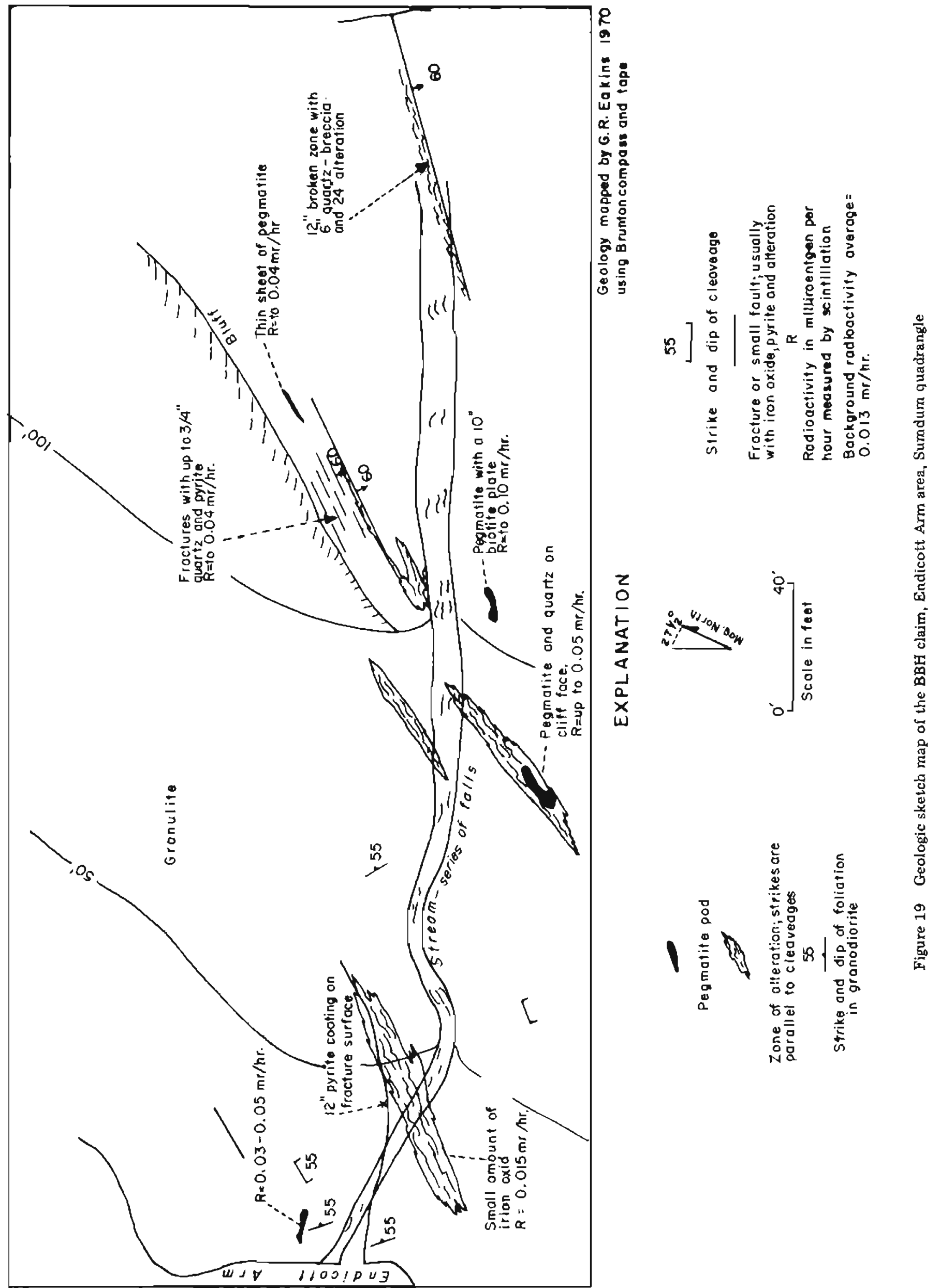


TABLE 7 -Atomic Absorption Analyses, Endicott Arm Area (anomalous value underlined)

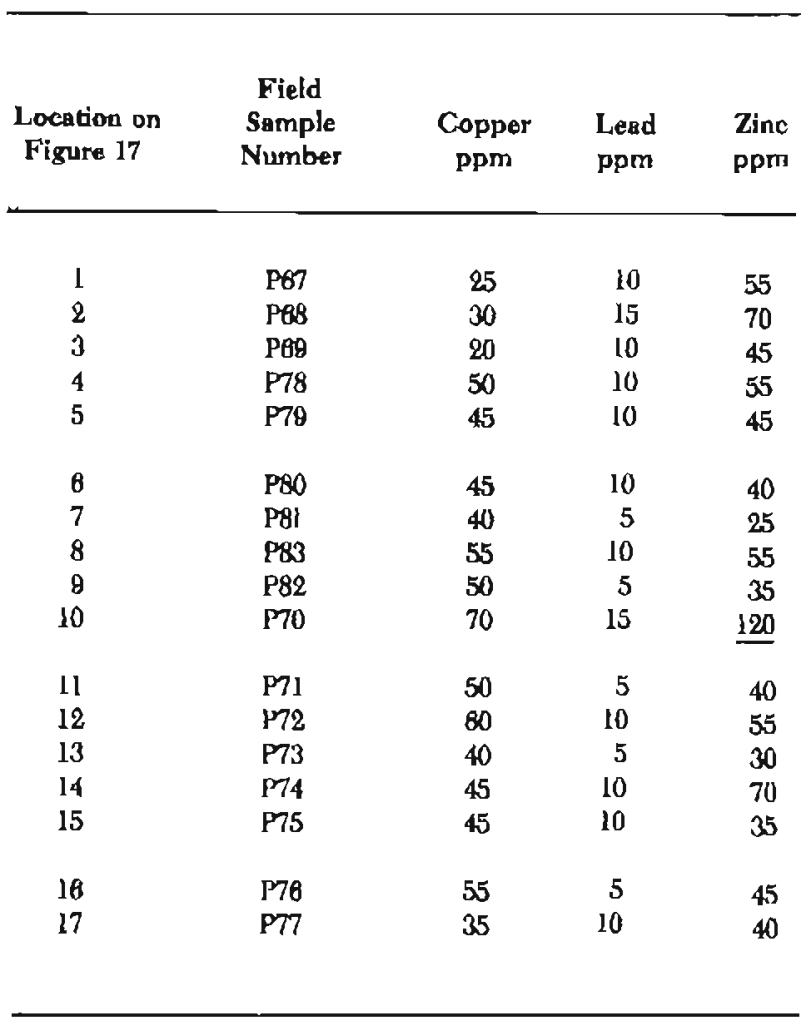

\section{CONCLUSIONS}

Pegmatites in the area do not appear to warrant further exploration for uranium. However, the fact that they do display a certain amount of radioactivity, combined with the possible presence of uranium 4 miles southwest of the BBH claim, may indicate that this region, between the Coast Range batholith and the Pacific Ocean, deserves more study. Sulfide deposits, especially those containing copper and silver, west of this claim, also may be favorable indicators, as uranium sometimes is associated with such deposits or is peripheral to districts that contain them.

\section{PORT CAMDEN AREA, KUIU ISLAND}

\section{LOCATION AND ACCESS}

The Port Camden area lies in the Petersburg D- 6 quadrangle 36 miles west of Petersburg. The area visited is on the west side of Port Camden on Kuiu Island, and can be reached by boat or loat plane. For this investigation a plane was chartered in Petersburg. Field work was confined to Tertiary sandstones and conglomerates along the west shore of Port Camden extending 5 miles south from the mouth of Kadak Bay.

\section{HISTOAY}

No prospects are known to the author in the immediate area, but barite and witherite deposits and a zinc prospect to the northwest around Saginaw Bay and on the Keku Islets have been known for many years. Logging has been extensive near the village of Kake and on the north side of Hamilton Bay about 10 miles north of Port Camden.

\section{GEOLOGY}

The Port Camden area is underlain by gently dipping Terdary volcanics and clastic sediments. These rocks presumahly overlie strongly folded Paleozolc sedimentary and metamorphic rocks that are exposed to the west on Kuiu Island and to the east in the vicinity of Dincan Canal on Kupreanof Island. The sediments at Port Camden have been discussed by Wright and Wright (1908, p. 59-60), Buddington and Chapin (1929, p. 281-283, 353), and Muffler (1967, p. C47.C50). Buddington and Chapin give an approximate total thickness of 2,850 feet for the Tertiary sequence at Port Camden. The upper 1,500 feet are volcanic rocks and the lower 1,350 feet consist of nonmarine sandstone and conglomerate with intercalated sills.

Nonmarine sandstones and conglomerates are exposed along the northern edge of the Tertiary deposits, from Kadak Bay south for about 5 miles. Similar material is present 5 to 8 miles to the northeast on the south side of Hamilton Bay east of Keku Strait. That area is one of very low relief and many swamps, and was not examined.

Reconnaissance mapping in conjunction with a radiometric survey in the area is shown on figure 21. The "felsite" shown there may correspond to rhyolite flows and breccia mapped by Bucddington and Chapin (1929, p. 263-264), and altered dellenite mapped by Muffler (1987, p. C48-C-49). The volcanics may be equivalent to gabbro and microgabbro mapped by Muffler (1987, p. C49). 

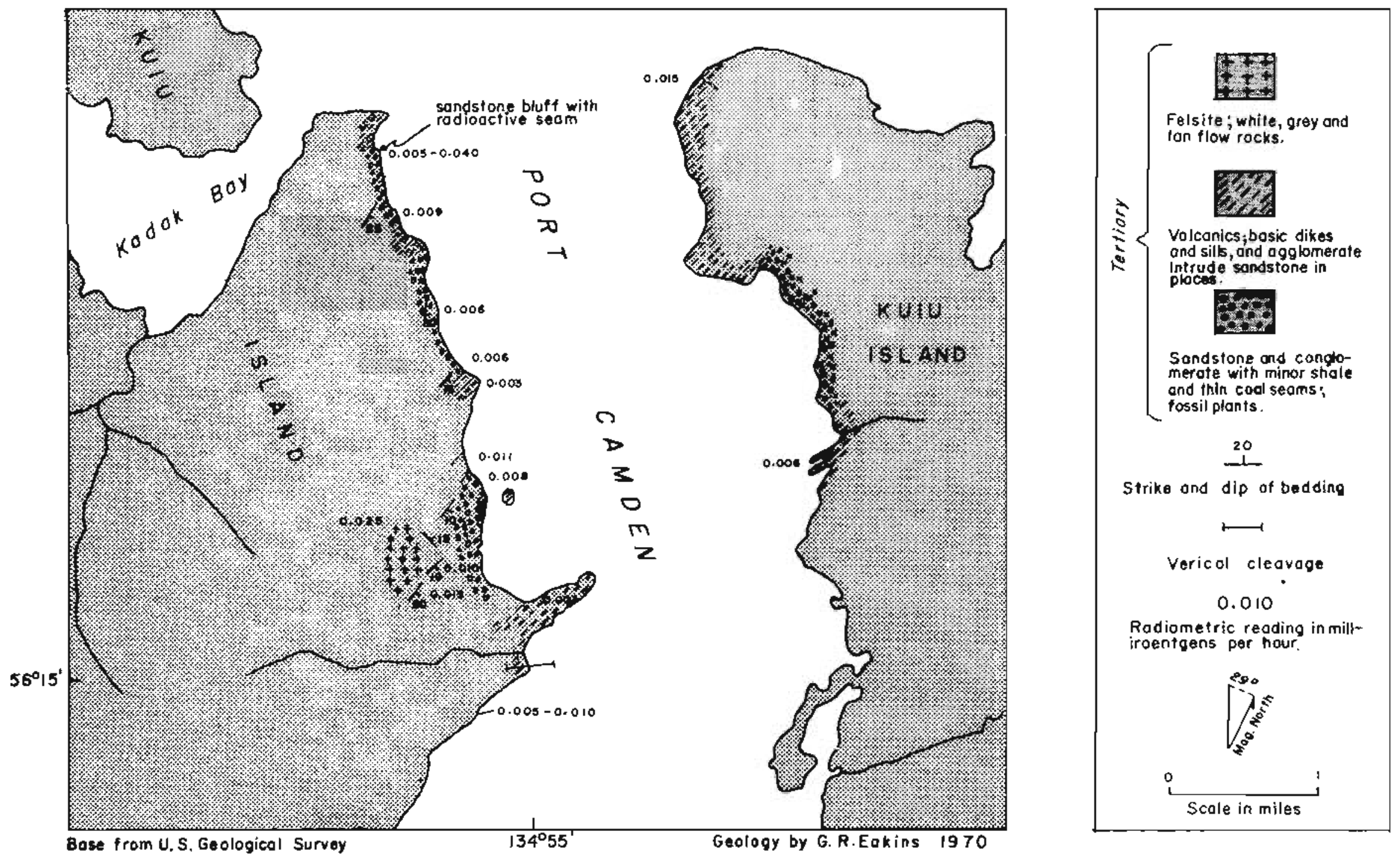

$\delta$ 


\section{MINERAL DEPOSITS}

Tertiary rocks are not known to be hosts for metallic ores in Southeastern Alaska. The nearest prospects are the barite and witherite deposits around Saginaw Bay and on the Keku Islets 10 to 15 miles north of Port Camden, and one zinc prospect on one of the Keku Islets (Buddington, 1925, p. 138-138). Coal seams in the sedimentary sequence at Port Carnden are much too thin to be of economic interest.

\section{RADIOME'TRIC SURVEY}

Radiometric testing with a scintillometer was done on foot, principally along the east side of Kuiu Island from Kadak Bay to a point about five miles south. Typical meter responses in milliroentgens per hour are shown on figure 21. The readings range from a low of $.003 \mathrm{mr} / \mathrm{hr}$ to a maximum of $.04 \mathrm{mr} / \mathrm{hr}$, a ratio of 13 to 1 . The relatively high response of $.025 \mathrm{mr} / \mathrm{hr}$ obtained at a conspicuous felsite bluff $1 / 2$ mile fron the coast is attributed to a high potassium content rather than uranium.

The strongest anomaly, .02 to $.04 \mathrm{mr} / \mathrm{hr}$, was found along a 4-inch bed of fine-grained sandstone within a 25 -foot bluff of massive sandstone $1 / 3$ mile south of a prominent point south of the mouth of Kadak Bay (fig. 21). ' 'wo chemical assays of this sandstone revealed II and $12 \mathrm{ppm}$ uranium, or about 5 times the average uranium content of sedimentary rocks. The radioactive seam is about 5 feet above beach level at its northern end, but dips gently south for about 100 feet. It is soft and red on weathered surfaces, but is hard and gray on fresh breaks. It has a very high magnetite content, estimated visually as $30 \%$. Fragments of rock up to $1 / 2$ inch in diameter will cling to a pocket magnet. Other visible minerals include pyríte, quartz, plagioclase, and mica flakes in a groundmass of very fine-grained altered material. The adjacent sandstone is light brown, softer, and appears to lack visible magnetite or pyrite. The sandstone immediately above and below the radioactive seam gave $.008 \mathrm{mr} / \mathrm{hr}$ and $.005 \mathrm{mr} / \mathrm{hr}$, respectively.

Other slightly anomalous readings from sandstone in the area ranged from .010 to $.023 \mathrm{mr} / \mathrm{hr}$. These were found along streams west of Port Camden near the southern end of the area mapped. Chemical assays of these zones yielded less than 2 ppm uranium.

\section{GEOCHEMISTRY}

Thirty-one sediment samples were collected from streams flowing east toward Port Camden (fig, 22). Atomic absorption analyses are given in table 8 . Histograms appear in figure 23 . The highest values were 45 ppm copper, 65 ppm lead, and $180 \mathrm{ppm}$ zinc. Sample location number 1 was slightly anomalous for copper, and number $2 A$ for lead and zinc.

TABLE 8.-Atomic Absorption Analyses, Port Camden Area (anomalous values underlined)

\begin{tabular}{|c|c|c|c|c|}
\hline $\begin{array}{l}\text { Location on } \\
\text { Figure } 22\end{array}$ & $\begin{array}{c}\text { Field } \\
\text { Somple } \\
\text { Number }\end{array}$ & $\begin{array}{c}\text { Copper } \\
\text { ppr }\end{array}$ & $\begin{array}{l}\text { Lead } \\
\text { ppm }\end{array}$ & $\begin{array}{l}\text { Zinc } \\
\text { ppm }\end{array}$ \\
\hline I & OP112 & 45 & 15 & 65 \\
\hline 2 & OP 94 & $\overline{15}$ & 15 & 140 \\
\hline 3 & OP 95 & 15 & 10 & 120 \\
\hline 4 & OP 98 & 15 & 10 & 85 \\
\hline 5 & UP & 10 & 15 & 120 \\
\hline$\theta$ & OP 97 & 10 & 20 & 85 \\
\hline 7 & OPIOI & 15 & 15 & 90 \\
\hline 8 & $O P 99$ & 15 & 15 & 95 \\
\hline$\theta$ & OPIOO & 15 & 15 & 100 \\
\hline 10 & OP102 & 10 & 20 & 70 \\
\hline 11 & OPIO3 & 15 & 20 & 80 \\
\hline 12 & UP 88 & 20 & 20 & 80 \\
\hline 13 & OPQO & 15 & 20 & $\infty 0$ \\
\hline 14 & OP91 & 10 & 20 & 120 \\
\hline 15 & $\mathrm{OP} 92$ & 15 & 15 & 80 \\
\hline 16 & OP93 & 15 & 15 & 90 \\
\hline 17 & OPH9 & 15 & 20 & 115 \\
\hline 18 & OP113 & 15 & 20 & 120 \\
\hline 19 & OP114 & 15 & 20 & 150 \\
\hline 20 & OP 87 & 10 & 15 & 110 \\
\hline 21 & OP 85 & 10 & 20 & 110 \\
\hline 22 & OP 84 & 10 & 15 & 85 \\
\hline 23 & OP 88 & 10 & 15 & 120 \\
\hline 24 & OPI05 & 15 & $\underline{\theta 5}$ & 100 \\
\hline 25 & OPIO4 & 10 & $\overline{25}$ & $\overline{100}$ \\
\hline 28 & OPI06 & 15 & 30 & 130 \\
\hline 27 & OPIO7 & 10 & 20 & 150 \\
\hline 28 & OP108 & 10 & 30 & 130 \\
\hline 29 & OPI0O & 15 & 25 & 120 \\
\hline 30 & OP110 & 10 & 15 & 110 \\
\hline 31 & OPl11 & 15 & 25 & 120 \\
\hline
\end{tabular}

\section{CONCLUSIONS}

Radioactivity in the thin bed of magnetic sandstone 


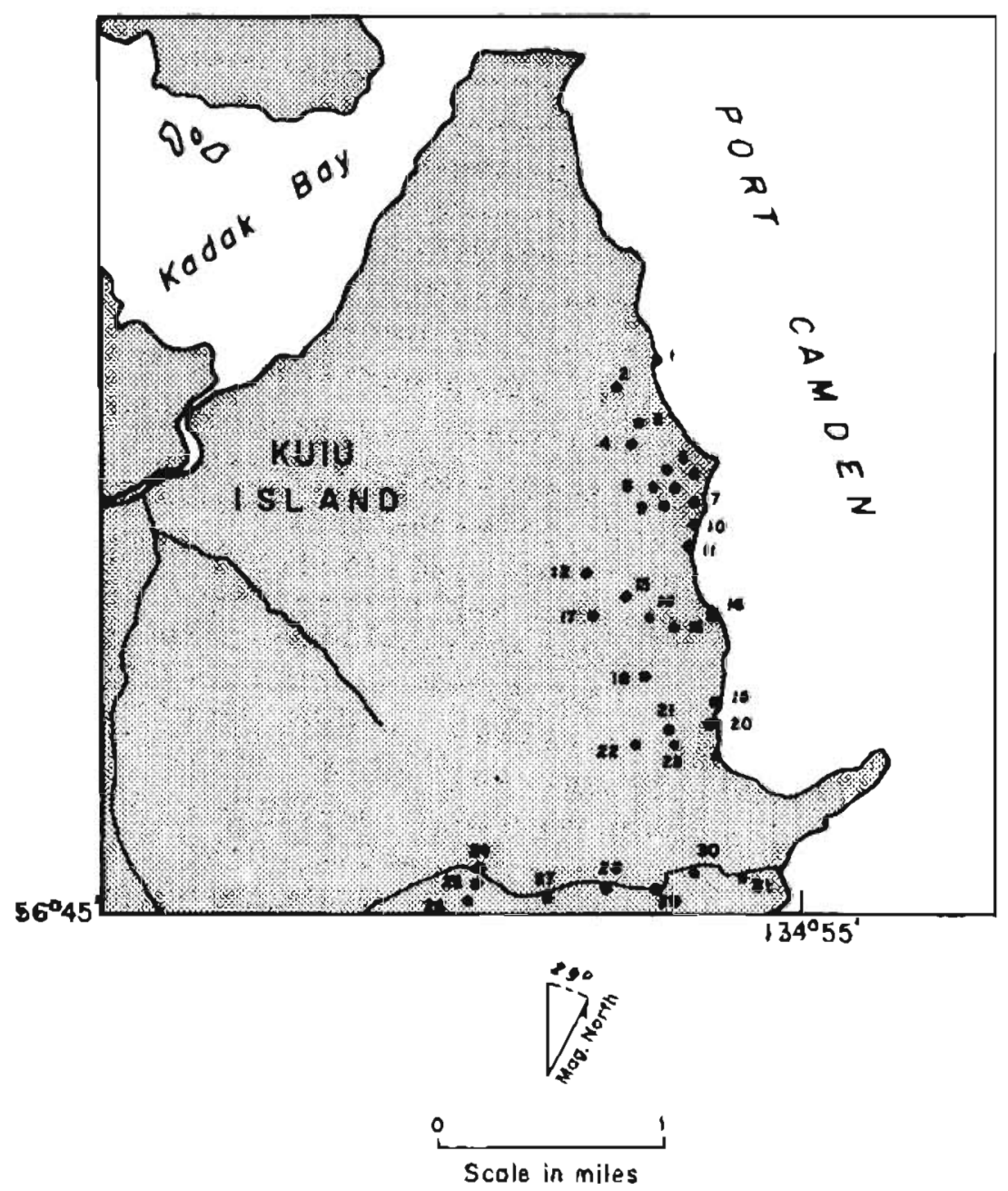

\section{EXPLANATION}

- |-3| Stream sediment sample location and number Analyses are listed in table 8

Figure 22 Locations of stream-sediment samples and prospects, part of the Port Camden area 


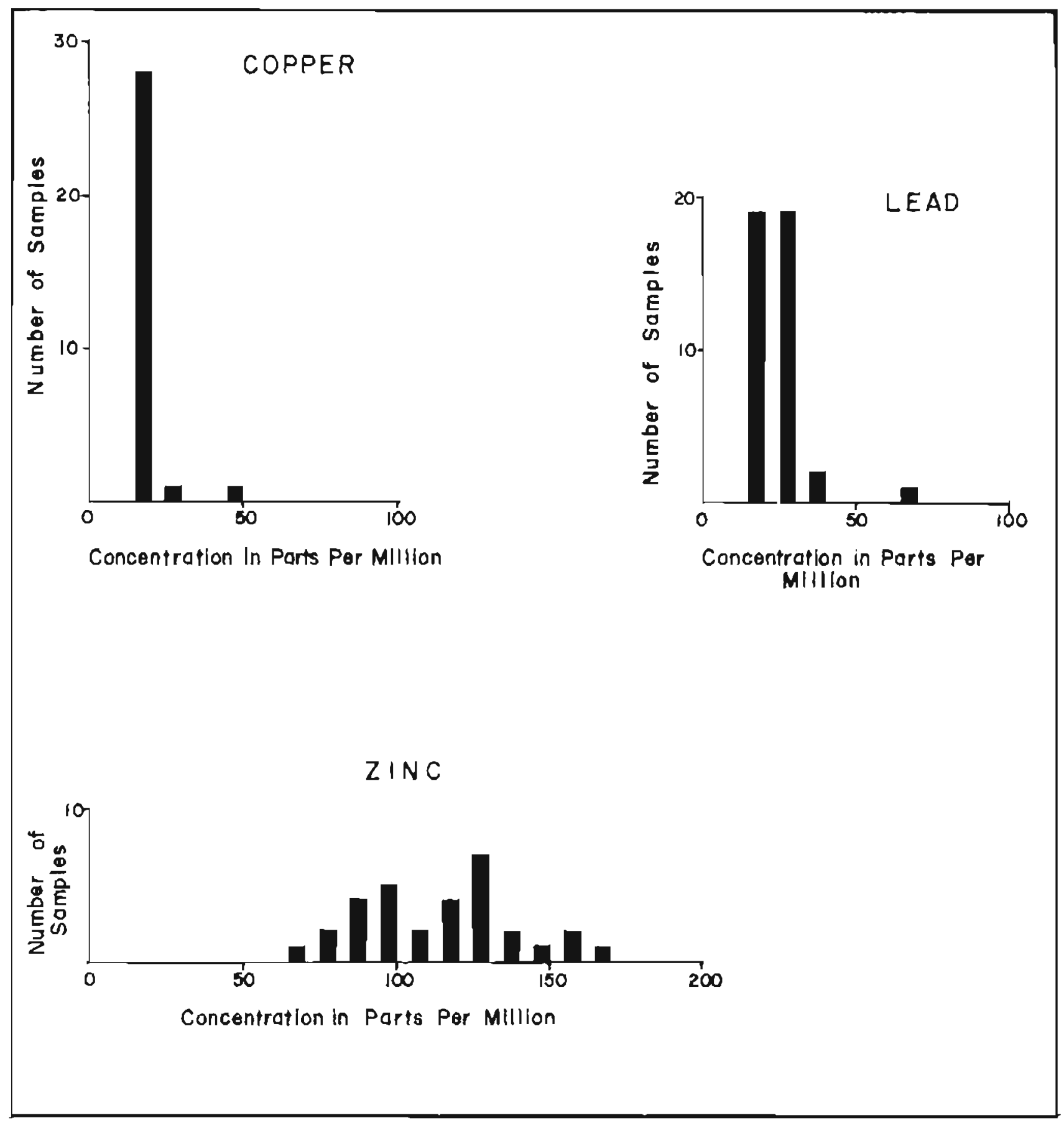

Figure 23 Frequency distribution histogram based on atomic absorption analyses for copper, lead, and zinc, Port Camden area 
is the strongest so far found by the author in sedimentary rock in Southeastern Alaska. While the level of radioactivity of this zone does not necessarily indicate commercial possibilities, it shows that a certain degree of concentration can take place in sandstone in this region. The bed probably represents a local placer-like accumulation of heavy minerals. The source of those minerals in uncertain, but they may have been derived from a granitic rock containing anomalous amounts of radioactive minerals. A more complete examination of the Tertiary sediments in the Port Camden-Hamilton Bay area, therefore, is recommended. It might reveal more anomalous radioactive material and aid in the determination of its source. Stream-sediment samples, on the other hand, did not indicate metal anomalies warranting further geochemical investlgations.

\section{CASTLE ISLANDS, DUNCAN CANAL}

A barite deposit on the east side of Castle Island in Duncan Canal 14 miles southwest of Petersburg (fig. 1 , area 9) is currently being mined by Alaska Barite Company for use as mud weighting material by the petroleum industry in Alaska. The Castle Island operation was visited during the course of the uranium project, but no radioactivity was detected at the barite deposit or on any of the nearby islands. Bedrock includes Devonian schist, greenstone, limestone (which is the host for the barite), and Tertiary volcanics. No geochemical sampling was done.

\section{VIRGINIA LAKE AREA， WRANGELL DISTRICT}

\section{LOCATION AND ACCESS}

Virginia Lake is on the mainland about 8 miles east of Wrangell townsite. The lake is approximately 2 miles long and $3 / 4$ mile from tidewater at an elevation of 100 feet. The most convenient means of access is by float plane. The U. S. Forest Service maintains a cabin near a sandy beach at the northeast end. A foot trail follows Mill Creek from the coast to the lower end of the lake.

\section{HISTORY}

Uranium investigation was limited to bedrock exposures within a short distance of the Virginia Lake shoreline. Tinere are no known mineral deposits within that area. However, a mineralized belt lies between 2 and 4 miles east of Virginia Lake, where considerable exploration and some underground work has been done on sulfide deposits. The visit to Virginia Lake was prompted by reported radioactivity on the north side of the Lake (William Huff, written commun., 1989).

\section{GEOLOGY}

The general geology of the region and mineral deposits east of Virginia Lake have been described by Buddington (1923, p. 58-63), Wright and Wright (1908. p. 188-190), and Gault, Rossman, Flint and Ray (1953, p. 15-55). Bedrock surrounding the lake is schist, marble, and quartz diorite (fig. 24). Bedding and cleaveage in the schist strike about $\mathrm{N} 35^{\circ} \mathrm{W}$ parallel to regional structure. A massive limestone bed crops out on the south side of the lake near its east end. Quartz. diorite is in contact with the schist at the eastern part of the lake. The quartz diorite is light gray, medium grained, crystaline to porphyritic, and contains up to $25 \%$ altered biotite.

\section{MINERAL DEPOSITS}

There are no known mineral deposits along the perimeter of Virginia Lake, but gold-silver-lead and ziac prospects have long been known at Berg Basin, Glacier Basio, Groundhog Basin, and the Lake group of claims (fig. 24). These lie within a northwesttrending metamorphlc sequence between areas of quartz diorite.

\section{RADIOMETRIC SURVEY}

Radiometric checks were made on bedrock along the shore of Virginia Lake and streams draining into the lake. Typical scintillometer responses are indicated on the geologic map (fig. 24). Average responses of 0.007 to $0.012 \mathrm{mr} / \mathrm{hr}$ were obtained for both quartz diorite and schist bedrock. The limestone bed yielded only $0.002 \mathrm{mr} / \mathrm{hr}$.

An anomalous zone was found in the schist along one stream north of the lake. This was examined from the shore up to an elevation of 350 feet. Readings ranged from 0.020 to $0.035 \mathrm{mr} / \mathrm{hr}$, or about four times average background. This zone apparently extends south to include an island near the south shore (fig. 24) where the average radioactivity was about $0.025 \mathrm{mr} /$ hr. The approximate position of the anomaly is indicated on the map. It is about on strike with the 


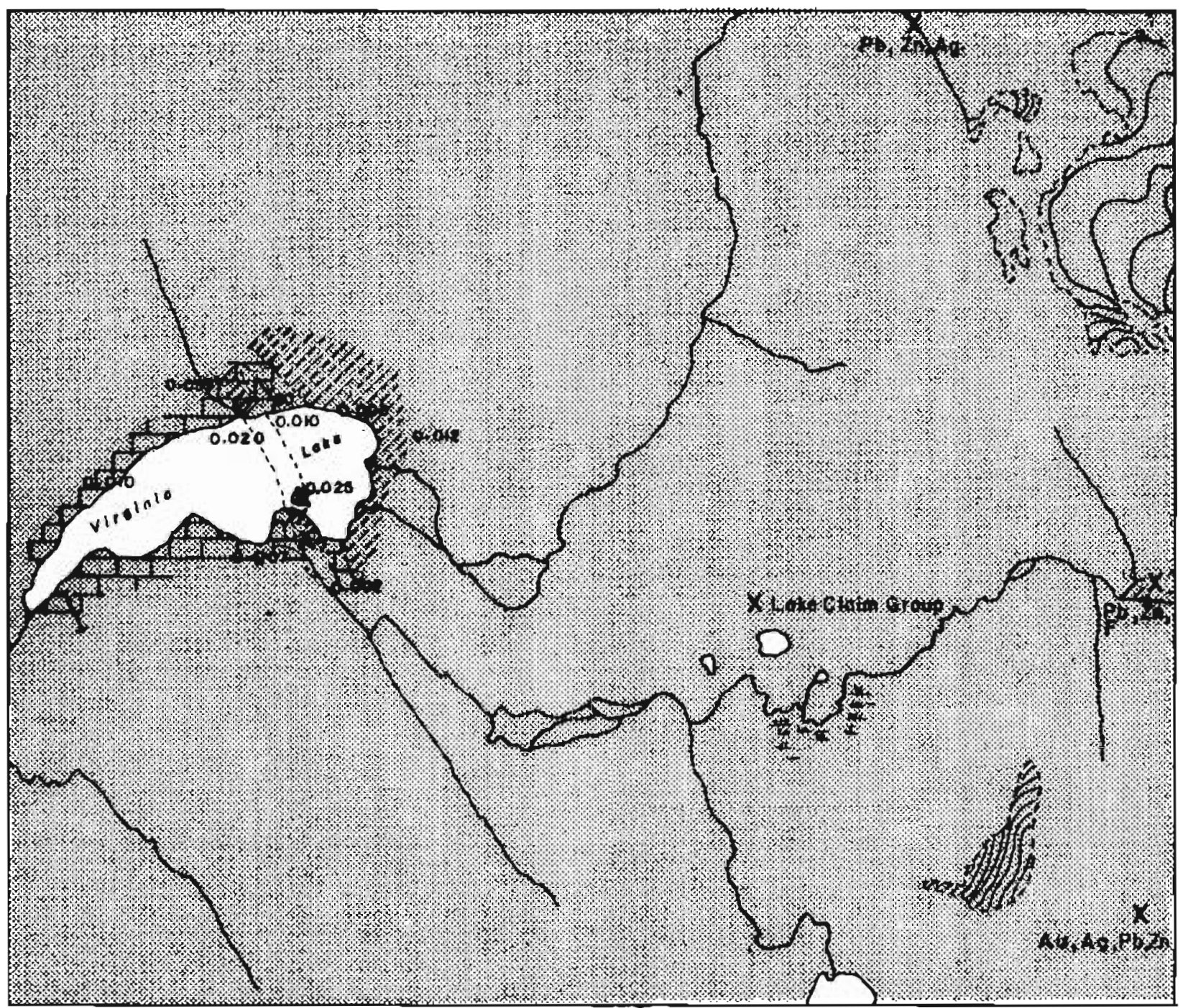

Bose from U.S.Geological Survey

$1,63,360$ Pet or sburg $B-1,1948$

Recomaissonce Geology by G.R. Eokins 1970

EXPLANATION

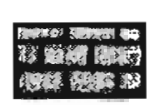

Schist

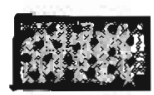

Marbia

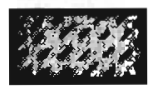

Quartz diorite

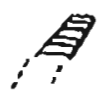

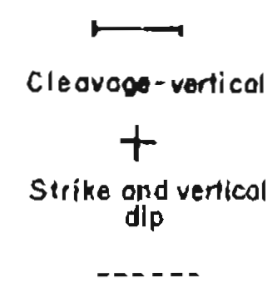

Approximate contact

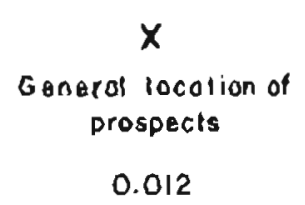

Rodiosetivity in milliroentgens per hour, moosured with acinillomoter

Zone of anomolous radioact tvity in schist

Figure 24 Reconnaissance geologic map and radiometric data, Virginia Lake area (fig. 1, area 10) 
limestone but they are probably separated by a fault.

No visible mineralized material or fault is associated with the anomaly. It is assumed that this zone contains the radioactivity reported by Huff, which is mentioned above. A chemical assay of a sample of the radioactive schist showed only $3 \mathrm{ppm}$ uranium. This is not adequate to account for the radiometric anomaly, which may be due to either high potassium or traces of thorium.

\section{GEOCHEMISTRY}

Seventeen stream-sediment samples were collected at Virginia Lake (fig. 25). Atomic absorption analyses are given in table 9 . Histograms appear in figure 26. The highest values were 90 ppm copper, 30 ppm lead, and $130 \mathrm{ppm}$ zinc. Samples from locations 4 and 16 were slightly anomalou's for zinc, but these values do not indicate that additional work is warranted.

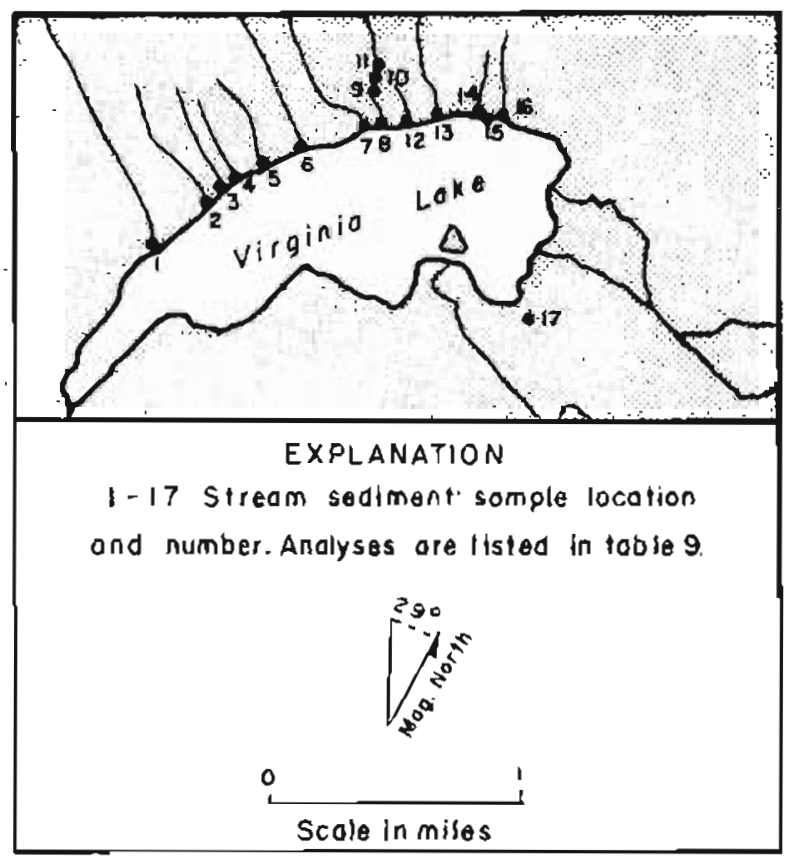

Figure 25. Virginia Lake area, stream-sediment sample locations

\section{CONCLUSIONS}

A weak radioactive zone in schist parallel to regional structure extends from an island near the south shore of Virginia Lake northwest to a point at least 350 feet above sea level in a stream valley north of the lake. The source of the radioactivity was not identified. The low level of radioactivity and the fact that it is not concentrated suggest that the possibilities for finding much uranium in the area examined are poor. Prospecting for radioactive materials near minneralized areas east of $V$ inginia Lake might be more worthwhile.

'IABLE 9.-Atomic Absorption Analyses, Virginta Lake Area (anomalous values underlined)

\begin{tabular}{|c|c|c|c|c|}
\hline $\begin{array}{l}\text { Location on } \\
\text { Figure } 25\end{array}$ & $\begin{array}{c}\text { Field } \\
\text { Sample } \\
\text { Number }\end{array}$ & $\begin{array}{c}\text { Copper } \\
\text { ppm }\end{array}$ & $\begin{array}{l}\text { Lead } \\
\text { pprn }\end{array}$ & $\begin{array}{l}\text { Zinc } \\
\text { ppm }\end{array}$ \\
\hline 1 & $P 143$ & 35 & 15 & 85 \\
\hline 2 & P142 & 25 & 10 & 85 \\
\hline 3 & Pl4l & 25 & 10 & 60 \\
\hline 4 & $\mathrm{Pl} 40$ & 45 & 30 & 130 \\
\hline 5 & P139 & 55 & 30 & $\overline{85}$ \\
\hline$\theta$ & Pl38 & (6) & 30 & 110 \\
\hline 7 & P137 & 90 & 25 & 80 \\
\hline 8 & P136 & 70 & 25 & 75 \\
\hline$\theta$ & E 27 & 65 & 30 & 70 \\
\hline 10 & E 28 & 65 & 30 & 65 \\
\hline 11 & $\mathrm{E} \not 29$ & 80 & 30 & 60 \\
\hline 12 & P135 & 30 & 20 & 85 \\
\hline 13 & $\mathrm{Pl} 34$ & 15 & 25 & 75 \\
\hline 14 & Pl3O & 30 & 25 & 100 \\
\hline 15 & PI32 & 5 & 15 & 85 \\
\hline 16 & PI3I & 5 & 25 & $\underline{130}$ \\
\hline 17 & $\mathrm{E} 30$ & 10 & 25 & $\overline{55}$ \\
\hline
\end{tabular}

\section{ZAREMBO ISLAND AREA}

\section{LOCATION AND ACCESS}

Zarembo Island is 25 miles southwest of Wrangell along Clarence Strait in the Petersburg quadrangle. It can be reached by boat or float plane.

\section{HISTORY}

The southwest coast of Zarembo Island from Macnamara Point soutbwest to a point opposite the south end of Bushy Island has been reported to contain minor uranium showings. There has been no mining in the area examined, but fluorite veins have been known along the shores for many years (Buddington, 1923, p. 75). 


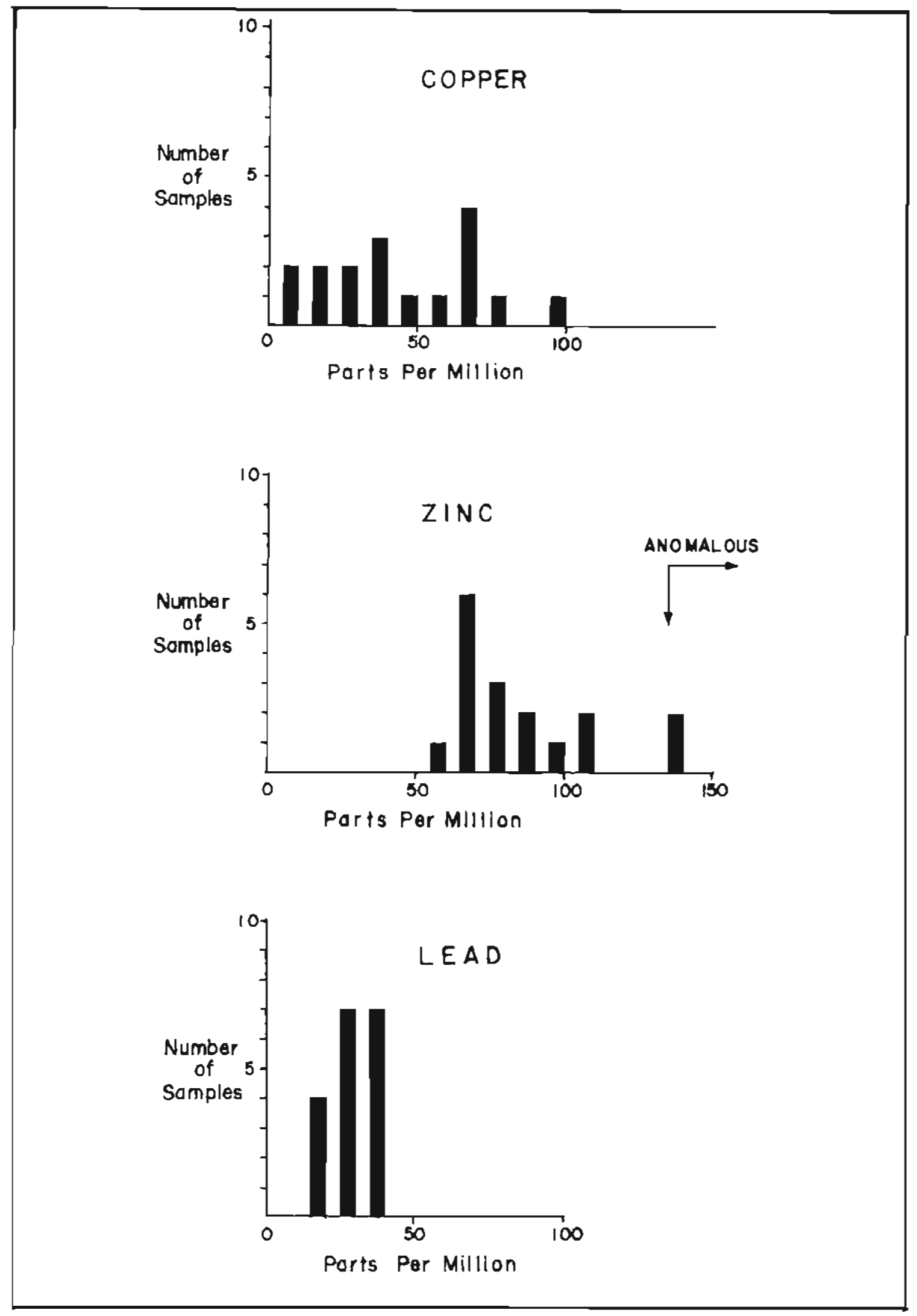

Figure 26 Frequency distribution histograms based on atomic absorption analyses for copper, lead, and zinc, Virginia Lake area 


\section{GEOLOGY}

The Tertiary rocks of Zarembo Island have been described by Buddington (1923, p. 75), Buddington and Chapin (1929, p. 261, 266, 272, 273), and Roehm (1942, p. 14; 1945, p. 11-12). The southwest coast of Zarembo Island is covered with Tertiary rocks, which include predominantly greenish lavas, agglomerates, tuffs, and more recent dikes. However, Tertiary sandstones, shales, and conglomerates are present for a distance of 4 miles, from a point $1 / 2$ mile south of Macnamara Point to a point on the coast approximately east of the north end of Bushy Island (fig. 27). The sandstone contains quartz, feldspar, and altered mica. At some locations it is conglomeratic and displays good cross-bedding. Interbedded shaley material is common and often contains fossil leaves. The sediments strike northwest and dip $20^{\circ}$ to $40^{\circ} \mathrm{E}$. Both felsic and basaltic dikes cut the sediments. Shear zones and fractures generally trend east-west.

Houston, Hates, Velikanje and Wedow (1958, p. 24) sampled granite at Round Point at the southern tip of Zarembo Island. The granite assayed $0.0048 \mathrm{eU}$, which is about average for granitic rocks.

White, West, l'olbert, Nelson and Houston $\{1952$, p. 16) sampled shear zones in basaltic, andesitic, and rhyolitic volcanic rocks in two areas on the west side of Zarembo lsland in 1951. They reported assays generally less than $0.001 \% \mathrm{eU}$, but locally the felsic rocks contained up to $0.005 \%$.

\section{MINERAI, DEPOSITS}

Fluorite veins cutting lava on the west coast of Zarembo Island have been described by Buddington (1923, p. 75) and Roehm (1942, p. 14; 1945, p. 11-12). These include irregular fracture fillings of quartz and fluorite at Point Nesbit, at a point 3 miles nor theast of Macnamara Point, and at a locality east of Bushy Island. The author examined the fluorite locality east of Bushy Island (fig. 27). Quartz and fluorite veins vary from 1 inch to 1 foot in width and trend roughly east-west. The quartz was deposited before fluorite. The veins were not always completely filled, so that fluorite frequently was euhedral.

\section{RADIOMETRIC SURVEY}

Scintillometer readings ranged from 0.005 to 0.025 $\mathrm{mr} / \mathrm{hr}$. The average background over sediments was about $0.008 \mathrm{mr} / \mathrm{hr}$. The highest readings were obtained over sandstone on the beach and on a small island close to shore about one mile south of Macnamara Point. This was a defínite anomaly, but a chernical assay of this material showed only $2 \mathrm{ppm} \mathrm{U}$. Thorium or potassium probably caused the anomalous readings. Volcanic tuffs and felsic dikes gave readings up to $0.02 \mathrm{mr} / \mathrm{hr}$, which are fairly common to felsic rocks. The tuffaceous material may be the source of a slight concentration of radioactive minerals in the sandstones.

\section{GEOCHEMISTRY}

Five stream-sediment samples were collected on Zarembo Island. Four were from a stream that enters Clearence Strait $21 / 3$ miles southeast of Macnamara Point. The fifth was collected near the mouth of a large stream opposite the south end of Bushy Island (fig. 27). Atomic absorption analyses are given in table 10. The highest values were $15 \mathrm{ppm}$ copper, $25 \mathrm{ppm}$ lead, and 100 ppm zinc. None is considered anomalous.

TABLE 10.-Atomic Absorption Analyses, Zarembo 7sland

\begin{tabular}{ccccc}
\hline $\begin{array}{c}\text { Location on } \\
\text { Figure 27 }\end{array}$ & $\begin{array}{c}\text { Field } \\
\text { Somple } \\
\text { Number }\end{array}$ & $\begin{array}{c}\text { Copper } \\
\text { ppm }\end{array}$ & $\begin{array}{c}\text { Lead } \\
\text { ppm }\end{array}$ & $\begin{array}{c}\text { Zinc } \\
\text { ppm }\end{array}$ \\
\hline 1 & PI18 & 10 & 15 & 85 \\
2 & P117 & 15 & 15 & 75 \\
3 & P115 & 15 & 15 & 85 \\
4 & P118 & 15 & 15 & 70 \\
5 & P119 & 10 & 25 & 100 \\
& & & & \\
\hline
\end{tabular}

\section{CONCLUSIONS}

The slight radiometric anomaly of $0.025 \mathrm{mr} / \mathrm{hr}$ found in sandstone along the coast is difficult to evaluate, because the zone examined has been subjected to wave action and weathering. Thus any uranium minerals originally present might have been largely leached out. A chemical assay did not reveal an unusual amount of uranium, and the radiometric anomaly may be due to thorium. Overlying tuffaceous beds are a possible source of uranium. However, the rocks examined lack good porosity, pyrite, or other indications of mineralization. 


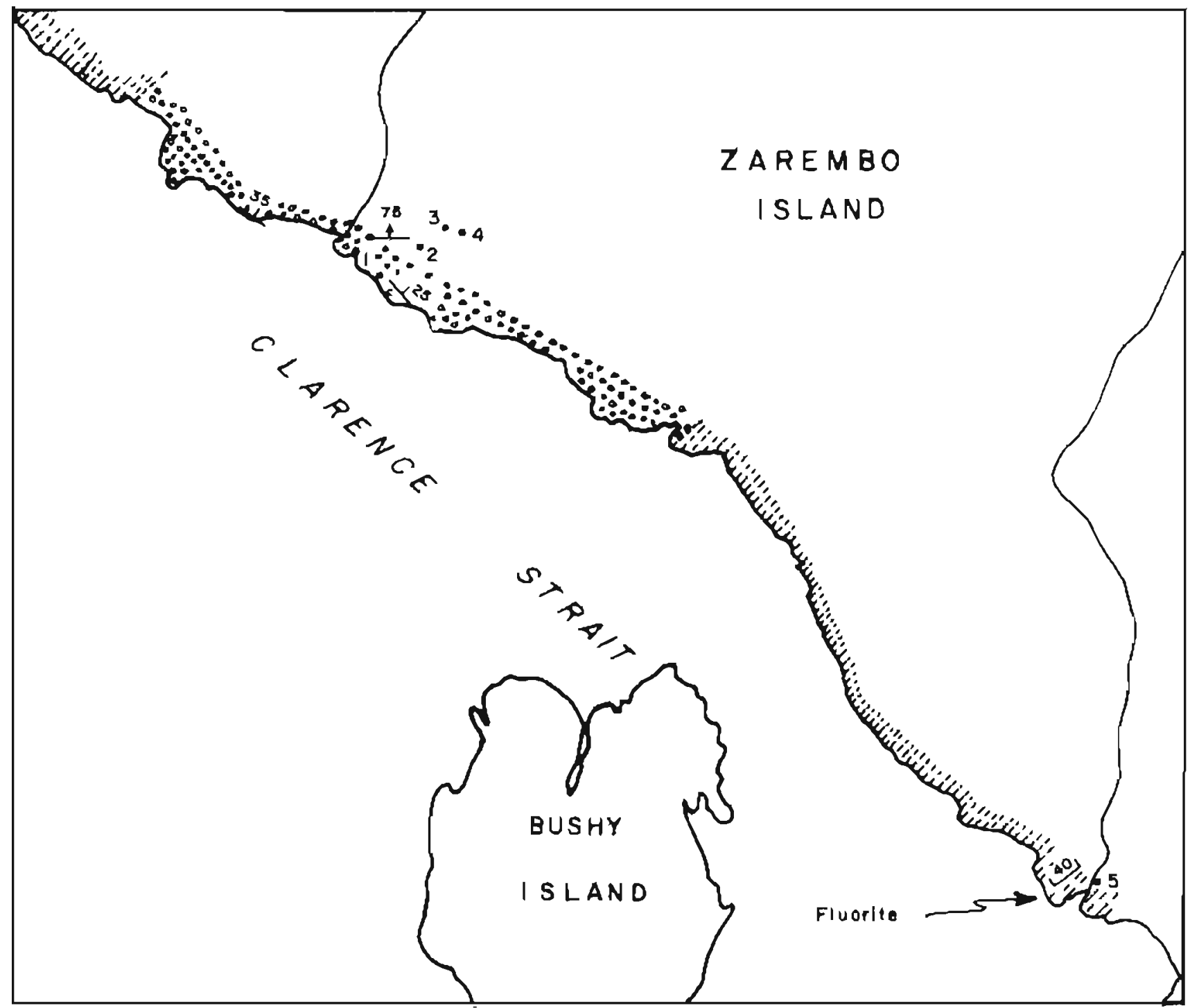

Bose from U.S.Goological Suproy

1:63,360 Potersburg $0-4,1951$

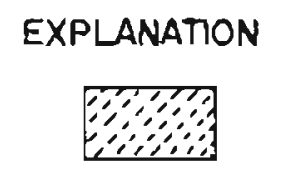

Bosalt and andesito

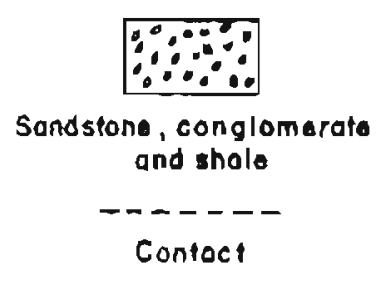

整

Foult; dip shown

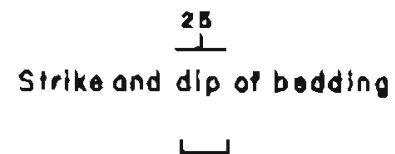

Strike and dip of jointing

$$
0.025
$$

Radiometric meosurements, milliroentgens per hour

$$
\text { - } 1-5
$$

Stream sediment sample and number. Nofe: Goochemicol dofa are llated in table 10

Figure 27 Geologic sketch map and stream-sediment sample locations, southwest coast of Zarembo Island (fig. 1 , area 11 ) 


\section{SALMON BAY AREA, PRINCE OF WALES ISLAND}

\section{LOCATION AND ACCESS}

The Salmon Bay area is on the northwest coast of Prince of Wales Island, about 35 miles southwest of Wrangell, in the Petersburg B-4 quadrangle. The area can be reached by boat or float plane. Salmon Bay is frequently used as an overnight harbor for fishing boats. One family runs a logging operation and has a float camp there.

\section{HISTORY}

On May 30, 1950, John Wandve of Ketchikan submitted to the Alaska Teritorial Department of Mines samples of red, jaspery rock from the northwest coast of Prince of Wales Island. These samples showed significant radioactivity and averaged $0.01 \%$ eU (Glover, 1951, p. 1). In July, 1951, Glover and mernbers of the U. S. Geological Survey Alaska Trace Elements Unit examined the area and found additional radioactive material both north and south of the original discovery near Salmon Bay (Ilouston, 1952 , p. 5). Claims were staked by various prospectors, but no subsurface exploration was done. Interest in the area led to a more detailed study by Houston, Bates, Velikanje and Wedow (1958, p. 6-23) during the summer of 1952 .

\section{GEOLOGY}

Geology of the Salmon Bay area was mapped by Buddington and Chapin (1929, pl. 1). Figure 28, adapted from that report, shows the general geology along a part of the coast visited in 1970 . Houston (1952), Houston, Bates, Velikanje, and Wedow (1958, p. 3-23), Glover (1951), and Wedow and others (1953, p. $6,9,13$ ) discussed the general geology in reports on radioactive veins in the aren. The following summary of geology is mostly taken from those sources.

The predominant bedrock unit in the area discussed is a thick graywacke formation of Silurian age, which is the host for radioactive veins. The graywacke sequence includes beds of indurated sandstone, shale, and conglomerate composed of pebbles and cobbles of greenstone, limestone, and granitic rock. A bed of conglomerate 300 to 400 feet thick is present at the base of the sequence. Part of the graywacke displays beds a few inches to several feet thick, but other parts are massive and difficult to djstinguish from volcanic rock. The strike and dip average about $\mathrm{N} 15^{\circ} \mathrm{W}$ and $45^{\circ} \mathrm{W}$, respectively. The graywacke is composed mostly of feldspar, chert, quartz, and iron oxides, but parts of it are very limy. The iron oxides impart a dark reddish color. Many fine-grained, steeply dipping basalt and lamprophyre dikes cut the graywacke. They vary in thickness from a few inches to 60 feet. Their age is believed to range from Cretaceous to Tertiary.

Thick, light colored, massive limestone of Silurian age underlies the graywacke 8 miles southeast of the entrance to Salmon Bay. Similar rock is exposed just west of Point Colpoys on the north coast of the Prince of Wales Island.

The only granitold rock seen in the Salmon Bay area during the 1970 investigation was a dark quartz diorite or granodiorite which forms the Rookery Islands in Clarence Strait (fig. 28). However, about 10 miles west of Salmon Bay on the western side of Prince of Wales Island there is a north-trending dioritic batholith approximately 15 miles long and 4 miles wide. This intrusive is thought to be an outlier of the Late Jurassic to Cretaceous Coast Range batholith. The dioritic rock of the Rookery Islands, the dikes, and the radioactive veins in this area may be of similar age. Figure 29 is a geologic sketch map showing the veins near the entrance to Salmon Bay.

A linear feature plotted from aerial photos probably is an expression of a bigh angle fault or large joint. This feature strikes $\mathrm{N} 20^{\circ} \mathrm{E}$ for at least 4 miles near the northwest comer of Fishery Island (fig. 28).

\section{MINERAL DEPOSITS}

The only mineral deposits known in the immediate vicinity of Salmon Bay are radioactive carbonate-hematite veins and nonradioactive rareearth carbonate veins found along 8 miles of coast between Point Colpeys and Pitcher Island (fig. 28). Veins having the strongest radioactivity are those on the east side of Fishery Island and on Pitcher Island. Most of the veins can be examined only at low tide. The radioactive veins are from 2 inches to $21 / 2$ feet wide, generally straight and steeply dipping. Their strikes are mostly north to $N 30^{\circ} \mathrm{W}$. They can be traced for 200 to 300 feet, but often they extend beneath water or soil and vegetation. Thus their true lengths cannot be measured easily. The vein material and the host rock are both stained about the same dark color. However, the veins can be traced as straight, shallow, notches, because the carbonate material erodes more easily than the argillite (fig. 30). There is no difference in appearance between the highly radioactive parts of 


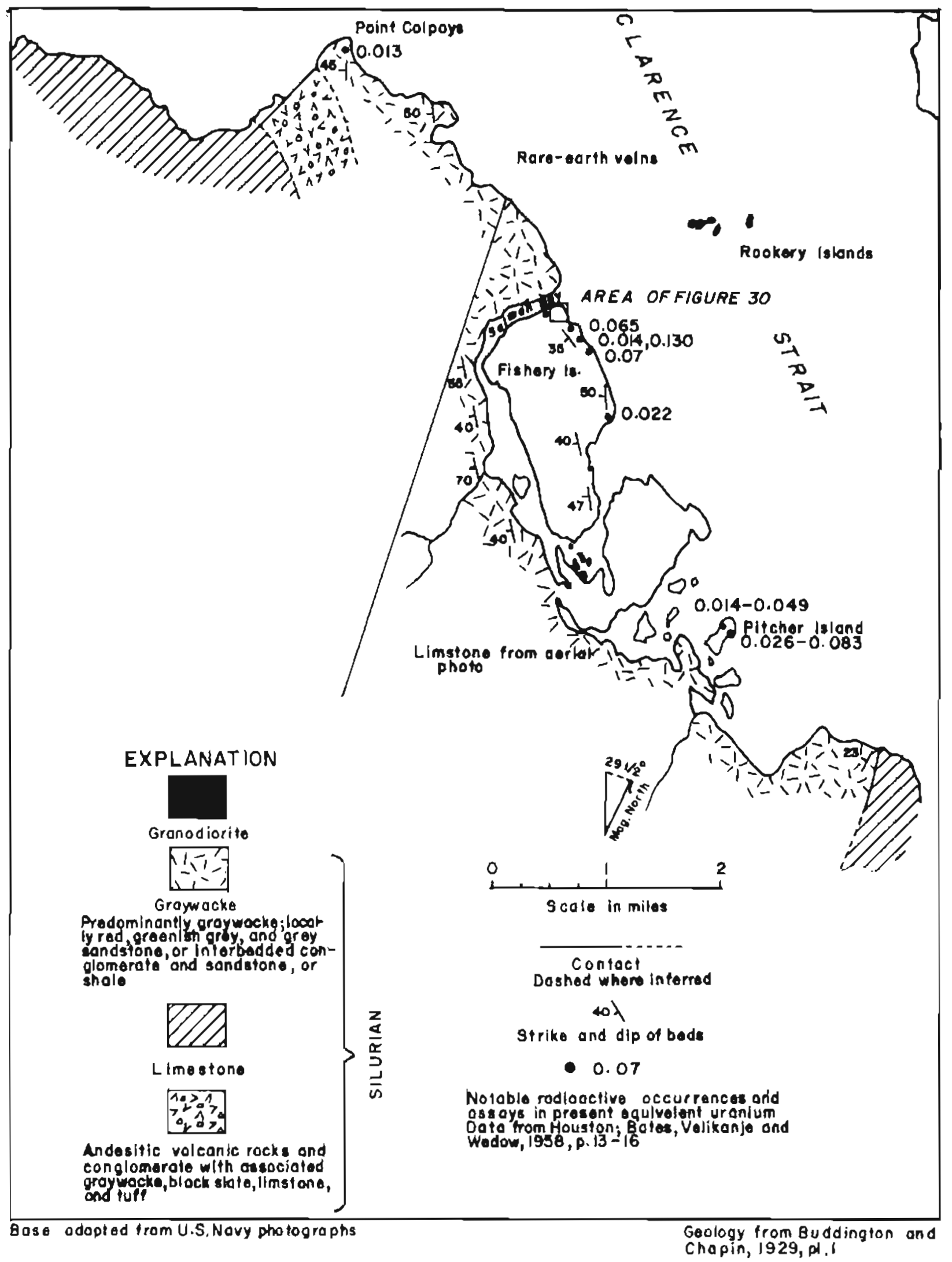

Figure 28 Geologic sketch map and radiometric data, Selmon Bay area, Prince of Wales Island (fig. 1, area 12) 


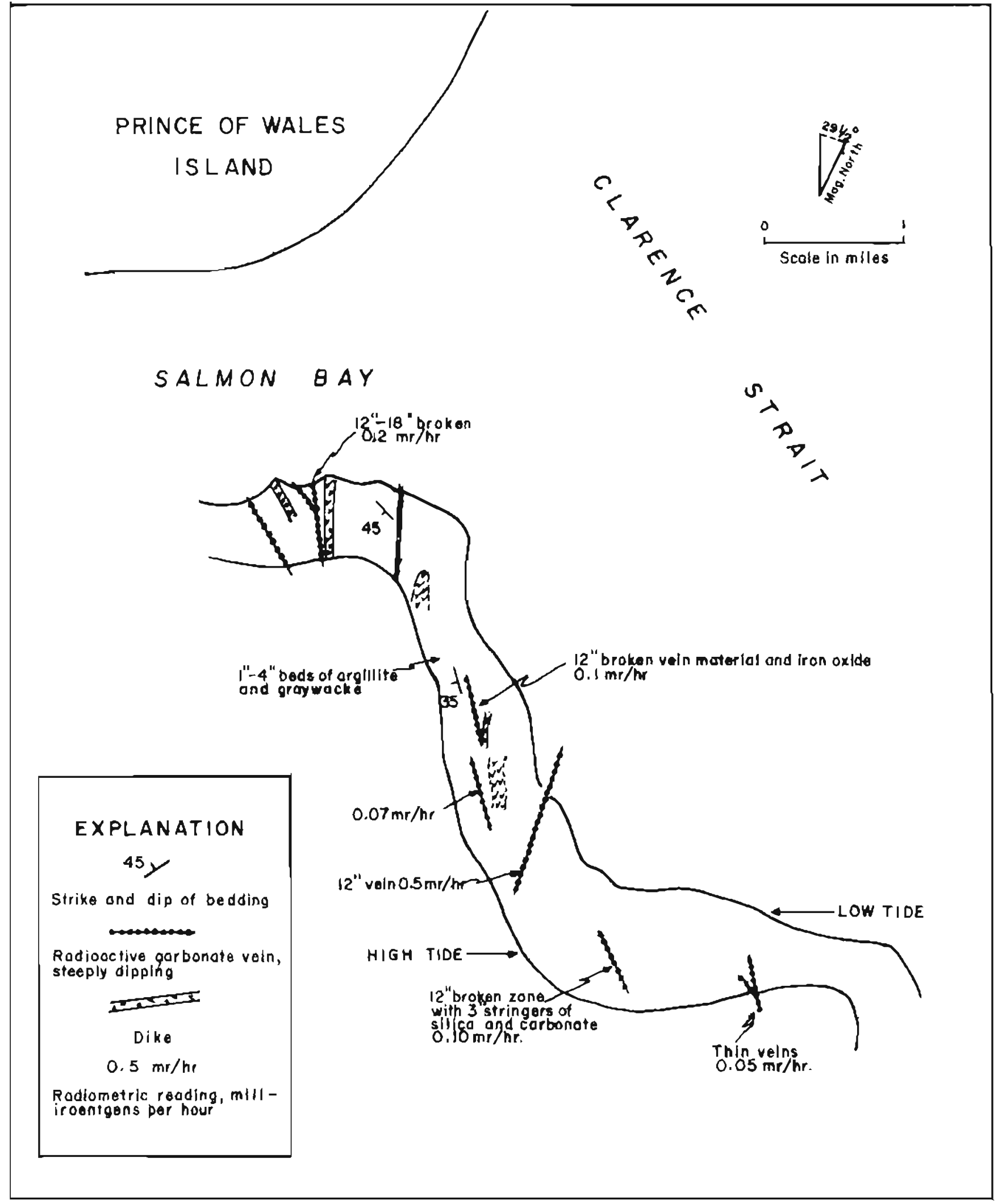

Figure 29 Geologic sketch map, shore near Salmon Bay, Prince of Wales Island 


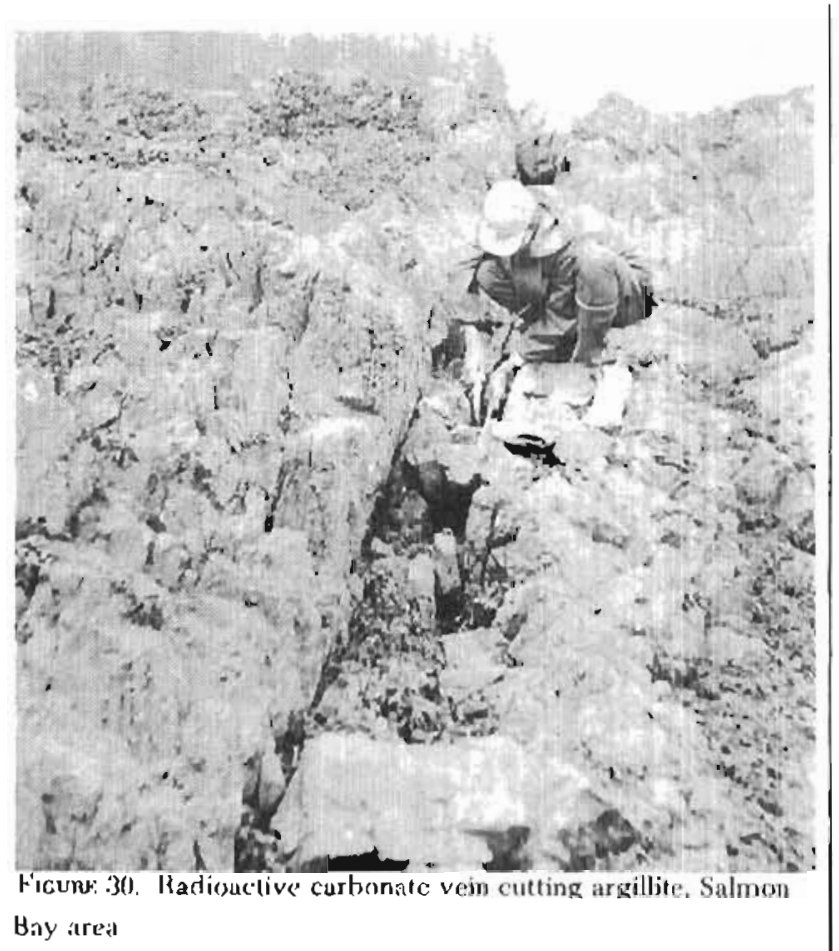

the veins and those parts with little or no radicactivity. Walls of the veins show some alteration and low radioactivity.

Composition of the veins was reported by Houston. Bates, Velikanje and Wedow (1958, table I) as 80 to $99 \%$ dolomite-ankerite. Alkalic feldspar is the next inost abundant mineral, comprising up to $10 \%$ of the vein material. Red in specular hematite was found in small a mounts in most veins. Pyrite is always present. A number of accessory minerals were found in trace amounts. The presence of fluorite, hematite and chalcedony are considered to be aids to prospecting. because these minerals are frequently ussociated with uranilum.

Thorite, monazite, zircon and apatite are the only radioactive minerals identified and are present only in small amounts. Hadioactive minerals could not be determined in some samples, but it was concluded that most radioactivity is due to thoriurn in thorite and monazite. Uranium appears to be present only in trace amounts. The highest grade sample was a grab sample taken near the entrance to Salmon Bay, which averaged $0.13 \%$ equivalent uranium and 0.648 equivalent thorium (Houston, Bates, Velikanje and Wedow, 1958, p. 12, 13). One channel sample taken along 100 feet of the Paystreak vein on Pitcher Island averaged $0.034 \%$ equivalent uranium and $0.16 \%$ thorium (Houston, Bates, Velikanje and Wedow. 1958 , p. 18). Assays were run on three of the most radioactive zones sampled by the present author in 1970. These produced only 10,7, and 3 ppm uranium, confirming that the radioactivity is due principally to thorium. However, due to the high solubility of uranium, it may originally have been present in greater quantities that have since been leached out of the near-surface portion of the veins.

Besides the radioactive veins, larger ones containing rare-earths, fluorcarbonate and hematite have been found one mile north of the entrance to Salmon Bay and on Pitcher Island. These are as much as 10 feet wide and 400 feet long. Assays reported by Houston, Bates, Velikanje and Wedow (1958, p. 19) show a maximum rare-earth oxide content of 5.0\%. Fourteen other assays ranged from $0.07 \%$ to $1.95 \%$ rare-earth oxides. The minerals parisite and bastnaesite were identified.

\section{RADIOMETRIC SURVEY}

The radiometric values at Salmon Bay were the strongest found in 1970. The background count measured with a scintillometer (Precision Radiation Instrument 117-B) was $0.015 \mathrm{mr} / \mathrm{hr}$. Radioactivity of the richest spots on the veins reached $5.0 \mathrm{mr} / \mathrm{hr}$, and up to 11,500 counts per minute with a four-channel spectrometer. Radioactivity varied along the veins but was found to be highest in narrow parts and particularly at the junction of veins. Radioactivity of the dioritic rock on the lioukery lslands was 0.015 $\mathrm{rnr} / \mathrm{hr}$, which is considered to be about normal for this type of igmeous rock. Because of the availability of sampling and assay data published by the U.S. Geological Survey no radiometric survey map is included in this report.

\section{GEOCHEMISTAY}

No geochernical samples were collected at Salmon Bay.

\section{CONCLUSIONS}

Control for ernplacement of the radioactive veins is principally struchural. Veins appear to be fillings in a particular set of fractures. The occurrence of radioactive veins only in graywacke is probably clue to the presence of open fractures during a time of hydrothernal activty in the area. Houston, Bates, Velikanje and Wedow (1958, p. 22) suggested that the carbonate-hematite veins are actually carbonatites. 
The nearest plutonic rock, not mentioned in earlier reports, is the granodiorite of the Rookery Islands. It is not known what relation this rock may have to the veins along the shore of Prince of Wales Island.

Information is limited due to a lack of geologic mapping on the northem part of the island and the dense vegetation and soil cover there. Careful work might reveal a wider distribution of veirs and disclose their relation to plutonic activity. The known veins are too low in uranium, thorium, and rare-eartlss to be of commercial value at present, and their mineralogy does not indicate that values would increase greatly with depth. Sorne increase in uranium may be expected though, because of near-surface leaching. The veins are of interest principally because they could be related to undiscovered mineralization in the interior of Prince of Wales Island and because highgrade uranium ore has been found near Kendrick Bay at the southem end of the island.

\section{DEVILFISH BAY AREA, KOSCIUSKO ISLAND}

\section{LOCATION AND ACCESS}

Devilfish Bay is on the east side of Kosciusko Island west of El Capitan Passage (fig. 31). It is in the Petersburg quadrangle about 50 miles south of Petersburg, and can be reached by boat or float plane. The area of primary interest is near the southwestern end of Devilfish Bay, where there are several mining clairns and prospects pits.

\section{HISTORY}

Claims were staked for copper and molybdenum near the head of Devilfish Bay in 1962 by Ketchikan prospectors. Assessment work and additional exploration were done subsequently. Herreid and Kaufman (1964, p. 9) made a brief visit to the area and described three prospects located near the head of Devilfss Bay (fig. 31). A major company staked claims in the area in 1969. Prospector Willian Huff noted anomalous radioactivity in the area and suggested that an investigation for uranium was justified.

\section{GEOLOGY}

Devilfish Bay lies on the east side of the Dry Pass dioritic batholith. Silurian graywacke and limestone are present as inclusions within the granodiorite near the southwest end of the bay (fig. 3I). Reaction between the sediments and the intrusive rocks has formed masses of brown and greenish garnet and marble. Some well developed garnet crystals up to 1 inch in diameter are present in the marble. Small deposits containing metallic minerals have been found in the contact metamorphic zone. Irregular pegmatite dikes within the diorite are exposed along the shore at the southwest end of the bay. These strike southwest and are up to 20 feet long.

\section{MINERAL DEPOSITS}

Only small pits and trenches have been dug to explore the sites. The two prospects (prospects A and B, fig. 31) closest to the bay contain pyrite, chalcopyrite and a little molybdenum. The third (prospect C, fig. 31) contains massive granular magnetite with minor chalcopyrite. Only the prospect nearest the shoreline was located during the Division's investigation in 1970. Figure 32 is a sketch of the pit showing exposed bedrock and radiometric readings. Considerable pyrite with minor chalcopyrite were found on a dump at the prospect. Molybdenum is reported to have been found here, but none was seen by the author. However, a 3-foot boulder containing molybdenite flakes up to $1 / 2$ inch in diameter was found a few hundred yards southeast of this prospect at an elevation of 350 feet.

Molybdenum deposits are known at Shakan, about 5 miles northwest of Devilfish Bay (Twenhofel, Robinson, and Gault, 1946, p. 19-30; Herreid and Kaufman, 1964, p. 1-9) where considerable development work was done during and shortly after World War I.

\section{RADIOMETRIC SURVEY}

Anomalous radioactivity was found at several points within the area examined. The average background over exposed granodiorite was approximately $0.008 \mathrm{mr} / \mathrm{hr}$. The pegmatite dikes along the shore registered up to $0.025 \mathrm{mr} / \mathrm{hr}$. Exposed granodiorite at an elevation of 130 feet on the south side of the bay produced $0.03 \mathrm{mr} / \mathrm{hr}$. The coppermolybdenum prospect (prospect A) contains one spot that registered $0.045 \mathrm{mr} / \mathrm{hr}$, the highest reading in the area. Most of the material in the prospect pit yielded $0.025 \mathrm{mr} / \mathrm{hr}$ or less. A chemical assay of a sample from the prospect produced a value of $8 \mathrm{ppm}$ uranium, about twice that of the average acid igneous rock. The 


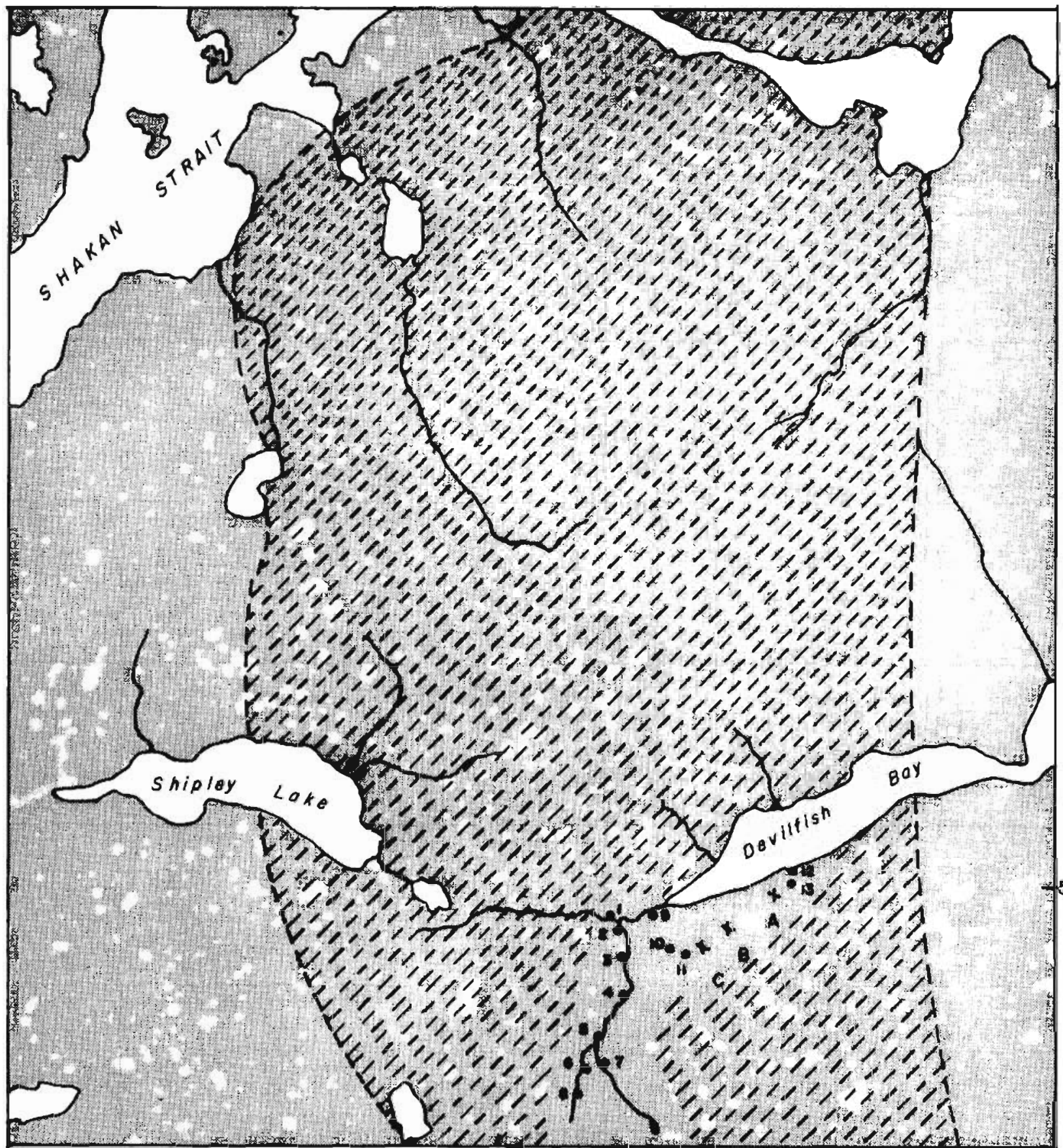

Bose from U.S.Geologicol Survey $133^{\circ} 25^{\prime}$

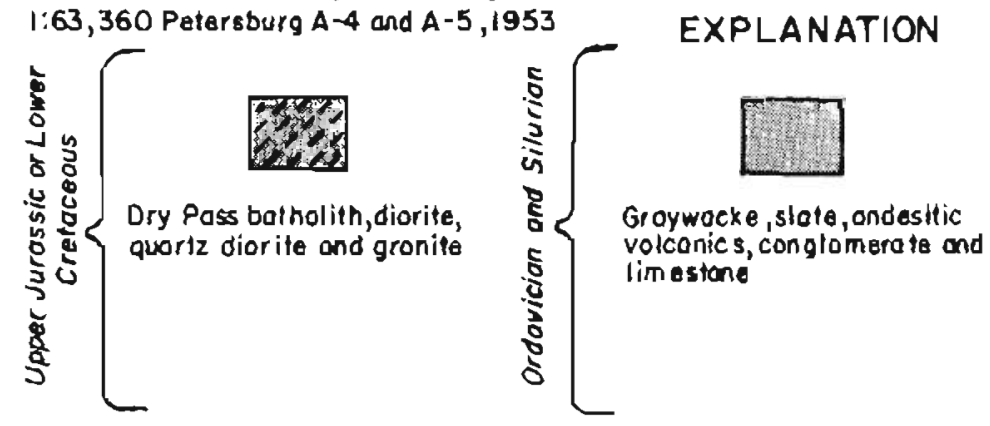

Geology from Buddington and Chapin, 1929, pl, I

- 1-13 Stroom sedimiment somple and location number. Anolyes are listad in table II.

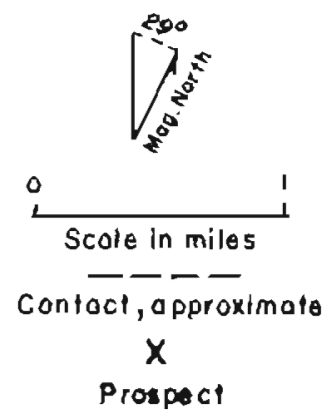

A

Prospect Pif

Figure 31 Locations of stream-sediment sampies, prospects, and part of the Dry Pass batholith, Devilfish Bay area (fig. 1, area 13) 


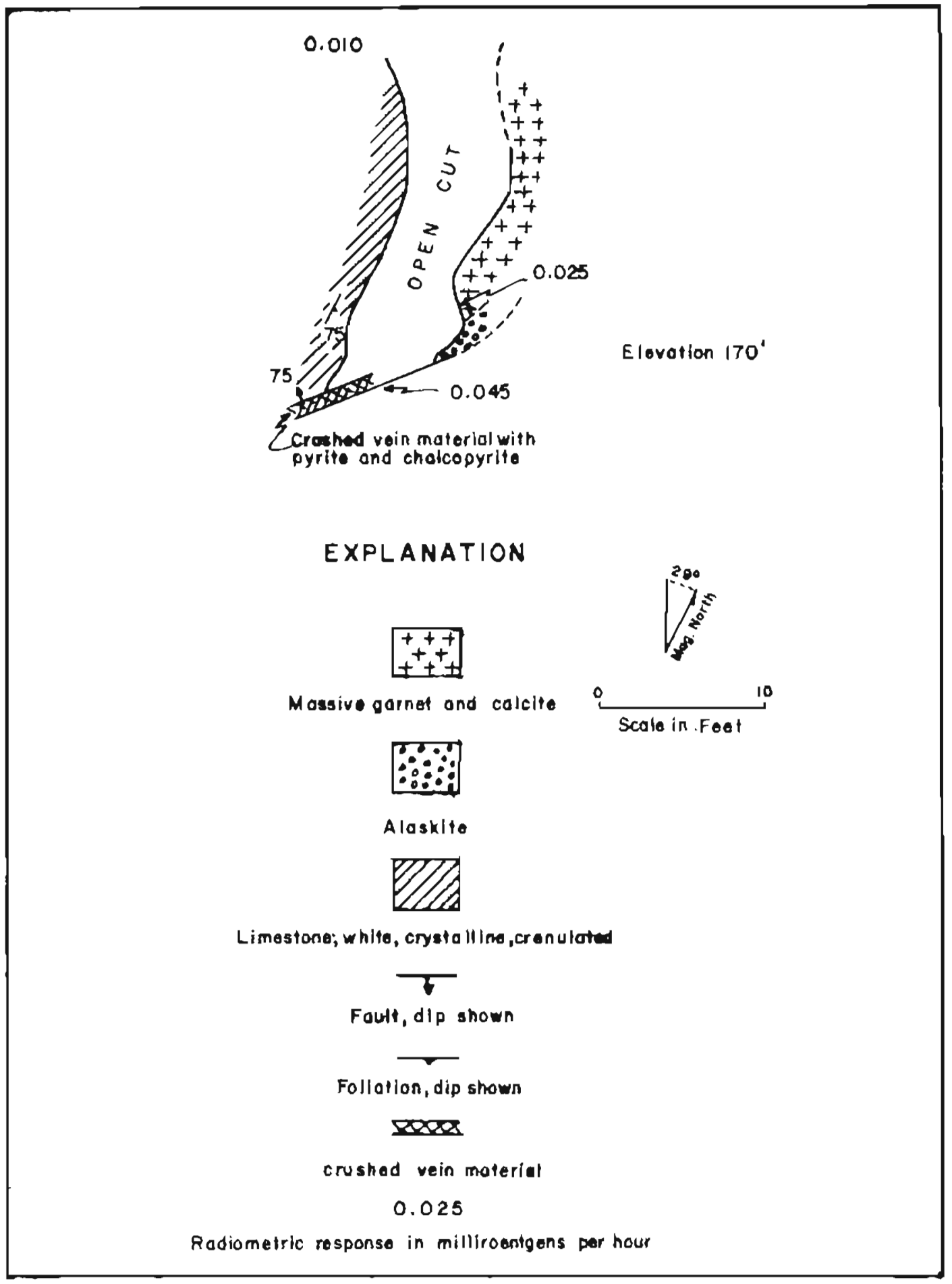

Figure 32 Geologic sketch map, prospect pit, Devilfish Bay 
radioactive mineral was not identfied.

\section{GEOCHEMISTRY}

Thirteen stream-sediment samples were collected at Devilfish Bay (fig. 31). Atomic absorption analyses are given in table 11. The highest values were $95 \mathrm{ppm}$ copper, $25 \mathrm{ppm}$ lead, and $90 \mathrm{ppm}$ zinc. Sample location 11 may be anomalous for copper, but too few samples were collected to draw any definite conclusions.

TABLE 11.-Alomic Absorption Analyses, Devilfish Bay Area

\begin{tabular}{ccccc}
\hline $\begin{array}{c}\text { Location on } \\
\text { Figure 31 }\end{array}$ & $\begin{array}{c}\text { Field } \\
\text { Sample } \\
\text { Number }\end{array}$ & $\begin{array}{c}\text { Copper } \\
\text { ppm }\end{array}$ & $\begin{array}{c}\text { Lead } \\
\text { ppm }\end{array}$ & $\begin{array}{c}\text { Zine } \\
\text { ppm }\end{array}$ \\
\hline 1 & P127 & 50 & 15 & 30 \\
2 & P128 & 15 & 10 & 25 \\
3 & P125 & 30 & 25 & 90 \\
4 & P124 & 10 & 10 & 20 \\
5 & P123 & 10 & 10 & 15 \\
& & & & \\
7 & P121 & 3 & 10 & 10 \\
7 & P122 & 30 & 10 & 35 \\
8 & P120 & 10 & 20 & 15 \\
10 & P128 & 35 & 10 & 35 \\
11 & P129 & 50 & 15 & 65 \\
12 & & & & \\
13 & P130 & 95 & 15 & 60 \\
& E 25 & 30 & 20 & 50 \\
& E 26 & 60 & 20 & 55 \\
\hline
\end{tabular}

\section{CONCLUSIONS}

Rather pronounced radioactive anomalies were found at Devilfish Bay, especially the $0.045 \mathrm{mr} / \mathrm{hr}$ reading obtained in the prospect pit containing pyrite, chalcopyrite and molybdenum. The mineralogy and general geology, however, do not suggest the presence of sufficlent uranium to justify exploration for this element. The anomalous radioactivity does illustrate how it may be associated with various mineral deposits and used as an aid in general prospecting.

\section{DALL BAY, GRAVINA ISLAND}

\section{LOCATION AND ACCESS}

A uranium prospect is located on the east side of Dall Head near the southero end of Gravina Island in the Ketchikan A- 8 quadrangle, 13 miles south of Ketchikan. Radioactive zones are exposed on the shore on the west side and near the north end of a small peninsula extending into Dall Bay (fig. 33). The area can be reached by boat or float plane.

\section{HISTORY}

The southern part of Cravina Island was an area of considerable prospecting and some mine development prior to 1915. During the winter of 1955 , Ketchikan prospectors discovered radioactivity south of the entrance to Dall Bay. Several lode claims, called the Black Jack group after the Black Jack Mining Company, were staked. Radioactive samples received by the Alaska Territorial Department of Mines led to an examination of the property (Williams, 1956). Assays on file at the Alaska Division of Geological Survey office record values up to $0.07 \%$ uranium, but one report mentions that one sample carried several pescent equivalent uranium.

During 1951, prior to the discovery of radioactivity on the Black Jack claims, White, West, Tolbert, Nelson, and Houston (1952, p. 15) made a reconnaissance survey for uranium along the southeast side of Gravina Island. They reported a maximum of $0.005 \%$ equivalent uranium in felsic volcanic rocks, but evidently did not find the radioactive material. 


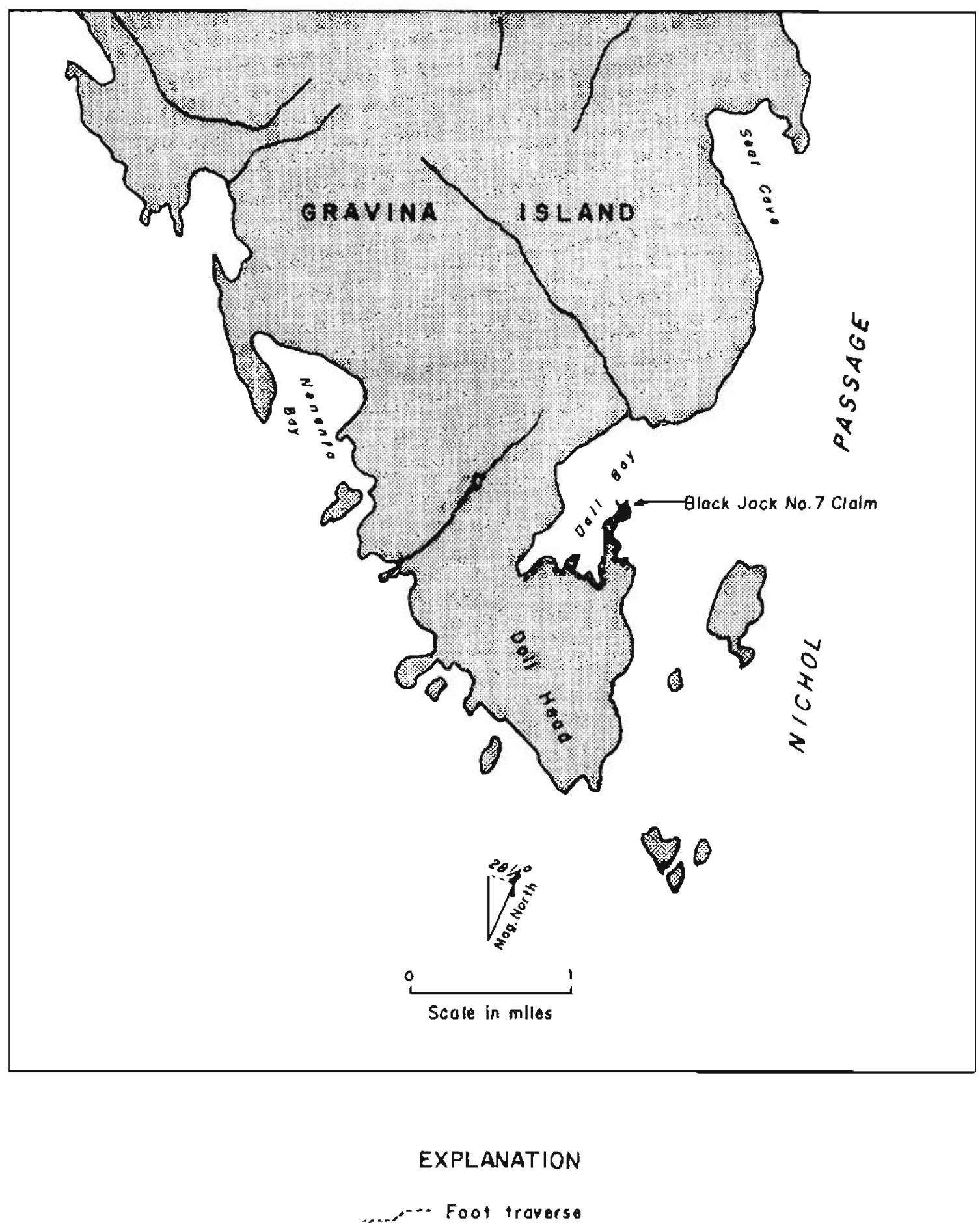

Figure 33 Dall Bay area, Gravina Island (fig. 1, area 14) 


\section{GEOLOGY}

Buddington and Chapin (1929, pl. 1) mapped the bedrock surrounding Dall Bay as Upper Jurassic or Lower Cretaceous quartz diorite to granodiorite. Inland from Dall Bay is a large area of banded gneiss. Farther west and north are limestone, conglomerate, schist, quartzite and greenstone. The present author noted medium-grained dioritic rock and basic and felsic dikes on the east side of Dall Bay. A sheared and brecciated zone 75 feet wide striking $\mathrm{N} 20^{\circ} \mathrm{E}$ is present on the west side of the small peninsula south of the entrance to the Bay. This zone contains angular fragments of dark fine-grained rock in a dolomite cement with some iron staining and a small amount of pyrite. The country rock is somewhat altered and slightly gneissic. Foliation trends $S 40^{\circ} \mathrm{E}$. Small felsic dikes and pods of feldspar exposed along the east side of the peninsula strike $\mathrm{N} 35^{\circ} \mathrm{W}$. These are slightly radioactive.

\section{MINERAL DEPOSITS}

Several copper deposits were discovered around 1900 between Dall Bay and Seal Cove, 2 miles to the north (Wright and Wright, 1908, p. 138-139; Brooks, 1902 , p. 38). The prospects are in sheared and brecciated zones cutting schist and metavolcanic rocks. Pyrite and chalcopyrite are the principle metals, but minor amounts of bornite, sphalerite, gold, and silver were reported. Small tonnages of ore were shipped from the Bay View and War Eagle properties west of Seal Cove.

Williams (1956) has described the radioactive material at the Black Jack No. 7 claim at Dall Bay. The discovery reportedly was made on a very thin seam or vein of radioactive material which contained several percent uranium, but very little was found. Two small excavations were made by blasting in an effort to follow the seam, but it apparently could not be traced either laterally or in depth. Two small mineralized areas were found in one pil but were only a fraction of an inch wide. The largest was on a joint or fault plane of slight displacement, and was apparently part of the "seam" from which the earlier samples were taken. The geiger counter gave readings of $2 \mathrm{mr} / \mathrm{hr}$ at both places. Immediately adjacent to the pits the general readings were above normal, but moving away from the pits in any direction brought the readings back to normal.
The country rock in the vicinity of the No. 7 discovery is a serpentinized basalt or gabbro. The serpentinized zone strikes north and dips $57^{\circ} \mathrm{W}$. A 2 $1 / 2$ foot layer or sill of pink feldspar (later identified as albite) lies on the hanging wall side of the fault plane from which the radioactive material was taken. The owners reported that the same association exists at their other showings. The actual uranium mineral resembles pitchblende.

\section{RADIOMETRIC SURVEY}

A radiometric examination of the coast from one mile south of the entrance to Dall Bay to an old sawmill site at the southern extremity of Dall Bay was made in 1970 using a four channel spectrometer. Pegmatite dikes and pods of albite on the east side of the small peninsula extending into Dall Bay produced up to 200 counts per minute against an average background of 75 counts. Feldspar pods at the Black Jack No. 7 claim on the west side of the peninsula produced up to 2,000 counts per minute. A chemical assay of the radioactive material collected in 1970 showed $80 \mathrm{ppm}$ \{0.008\%) uranium. However, small hand samples of material from the area produce only a very slight amount of radioactivity. The feldspar pods are at two places about 100 feet apart. These are irregular and measure up to $21 / 2$ feet wide and 10 feet long. They are adjacent to small serpentinized zones. The feldspar is reddish and coarsely crystalline. No metallic minerals were seen and the most radioactive portions of the pods appear to be associated with thin black coatings along fractures in the feldspar. No minerals other than feldspar could be recognized. The prospect pit mentioned by Williams was not found.

\section{GEOCHEMISTHY}

No geochemical sampling was done at Dall Bay.

\section{CONCLUSIONS}

The radioactive material exposed at the Black Jack No. 7 claim does not suggest commercial possibilities at that immediate location. However, the radioactivity may have significance by being associated with undiscovered deposits in the general area. This possibility is mentioned because radioactive dikes are known to be present as much as 8 miles distant around the high-grade uranium deposit at Bokan Mountain on Prince of Wales Island, about 22 miles southwest of Dall Bay. 


\section{REF EREN C ES}

Bates, R. C.; Wedow, Helmuth, Ir., 1953, Preliminary summary review of thorium-bearing mineral occurrences in Alaska: U. S. Geol. Survey Circ. 202. $12 \mathrm{p}$.

Berg, H. C., 1060, Three areas of possible mineral resource potential in southeastern Alaska, in Short papers in the geological sciences: U. S. Geol. Survey Prot. Paper 400-B, p. B39

Berg. H. C.; Cohb, E. H.. 1987. Metalliferous lode deposits of Alaska: U. S. Geol. Survey Bull, 1246, p. $145-148$

Brew, D. A.; Loney. K. A.; Muffler, L. J. P., 1966, Tectonic history of southeastem Alaska, in Special Volume No. 8. Tectonic history and mineral deposits of the westem Cordillera: Canadian Institute of Mining and Metallurgy, p. 149-170

Brooks, A. H., 1902, Preliminary report on the Ketchikan mining district, Alaska: U. S. Geol. Survey Prof. Paper 1, $118 \mathrm{p}$.

Buddington, A. F., 1923, Mincral deposits of the Wrangell district, in Brooks, A. H., and others, Mincral Resources of Alaska: U. S. Geol. Survey Bult. 739,169 p.

Buddington, A. F., 1925, Mineral investigations in southeastern Alaska, in Brooks, A. H., Mineral Resources of Alaska: U. S. Geol. Survey Bull. 773, $263 \mathrm{p}$.

Buddington, A. F; Chapin, Theodore, 1929, Geology and mineral deposits of southeastern Alaska: $U$. S. Ceol, Survey Bull. 800, 394 p.

Clark, A. L.; Brew, D. A.; Grybeck, D. A.; Wehr, Raymond, 1970, Analyses of rock and stream-sediment samples from the Sumdum C-4 quadrangle, Alaska: U. S. Geol. Survey open-file report No. 435, 86 p.

Clark, F. W.; Washington, H. S., 192A, The composition of the Earth's crust: U. S. Geol. Survey Prof. Paper 127

Cobb, E. H., 1980, Antimony, bismuth and mercury occurrences in Alaska: U. S. Ceol. Survey Mineral Resource Inv. Map MR-8

- 1970a, Uranium, thorium and rare-earth elements in Alask: U. S. Geol. Survey Mineral Inv. Resource Map MR -56

- 1970b, Bismutb occurrences in Alaska: U. S. Geol. Survey Mineral Inv. Resource Map MR-53
Dall, W. H., 1888, Feport on coal and lignite of Alaska: U. S. Geol. Survey Ann. Hept. 17, p. 1

Eakins, G. R., 1999. Uranium in Alaska: Alaska Div. Mines and Geology Geol. Rept. No, 38, 49 p.

- 1970, An experiment in geobotanical prospecting for uranium, Bokan Mountain area, southeastem Alaska: Alaska Div. Mines and Geology Geol. Rept. No. 41, 50 p.

Fald, Henry, 1954, Nuclear Geology: John Wiley and Sons, Inc., $414 \mathrm{p}$.

Forbes, R. B., 1959, The geology and petrology of the Juneau ice field area, southeastern Alaska: Univ. Wasbington dissertation, $\mathrm{PhD}, 259 \mathrm{p}$.

Fowler, H. M., 1949, Mountain View property. Hyder district: Aluska Terr. Dept. Mines Itinerary Rept., 5 p.

Freeman. V. L., 1963, Examination of uranium prospects, 1956, in Contributions to econonic geology: $U$. S. Geol. Survey Bull. 1155, $90 \mathrm{p}$.

Gault, H. R.: Fellows, R. E., 1953, Zinc-copper deposits at Tracy Arm, Potersburg district, Alaska: U. S. Geol. Survcy Bull. 998-A, 11 p.

Gault, H. R.; Rossman, D. L.; Flint. G. M.; Ray, R. G. 1953. Some zinc-lead deposits of the Wrangell district, Alaska: U. S. Geal. Survey Bull. 998-B, $55 \mathrm{p}$.

Glover, A. E., 1951, Salmon Bay-Red Bay reconnaissance, Prince of Wales Island: Alaska Terr. Dept. Mines Mineral Inv. 117-1, 6 p.

Heiner, L. E.; Wolff, E. N., 1938, Mineral resources of northern Alaska: Univ. Alaska, Mineral Industry Research Lab. Rept. No. 18, 299 p.

- 1970, Southeastem Alaska mineral commodity maps: Univ. Alaska Mineral Research Lab. Rept. No. 25

Herbert, C. F.; Race, W. H., 1984, Geochemical investigations in selected areas in southeastern Alaska, 1964: Alaska Div Mines and Minerals Geochem. Repl, No, 1, 30 p.

- 1985, Geochemical investigations of selected areas in southeastem Alaska, 1964 and 1985: Alaska Div. Mines and Minerals Geochem. Rept. No, 6. $64 \mathrm{p}$.

Herreid, Gordon. 1962, Preliminary report on geologic mapping in the Coast Range mineral belt, Alaska: Alaska Div. Mines and Minerals Geol. Rept, No. 1, $29 \mathrm{p}$. 
Herreid, Gordon, Kaufman, M.A., 1964, Geology of the Dry Pass area, southeastern Alaska: Alaska Div. Mines and Minerals Geol. Kep. No. 7, 11 p.

Houston, J. R, 1952, Interim report on the radioactive carbonate-hematite veins near Salmon Bay, Prince of Wales Island, southeastern Alaska: U. S. Geol. Survey Trace Elements Mem. Rept. 356, $17 \mathrm{p}$.

Houston, J. R.; Bates, R. G; Velikanje, H. S.; Wedow, Helmuth, Ir., 1958, Reconnaissance for radioactive deposits in southeastern Alaska, 1052: U. S. Geol. Survey Bull. 1058-A, 29 p.

Kaufman, Alvin, 1958, Southeastern Alaska's mineral industry: U. S. Bur. Mines Inf. Circ. 7844,37 p.

Lang, A. H., 1949, Notes on prospecting for uranium in Canada: Geol. Survey Canada Paper 49-4, $17 \mathrm{p}$.

Lanphere, M. A.; Loney, R. A.; Brew, D. A., 1985, potassium-argon ages of some plutonic rocks, Tenakee Area, Chichagof Island, southeastern Alaska: U. S. Geol. Survey Prof. Paper 525 B, p. B108-B111

Lanphere, M. A.; MacKevett, E. M., Jr.; Stern, T. W., 1864, Potassium-argon and lead-alpha ages of plutonic rocks, Bokan Mountain area, Alaska: Science, v. 145 , nu. 3833, p. $705-707$

Lathram, E. H.; Loney, R. A.; Condon, W. H., Berg, H. C., 1959, Progress map of the geology of the Juneau quadrangle, Alaska: U. S. Geol. Survey Misc. Geol. Inv. Map 1.303

Lathram, E. H.; Pomeroy, J. S.; B̈erg, H. C.; Loney, R. A., 1905, Reconnaissance geology of Admiralty Istand. Alaska: U. S. Geol. Survey Bull. 1181-R, $45 \mathrm{p}$.

Loney, R. A.; Berg, H. C.; Pomeroy, J. S.; Brew, D. A., 1983, Reconnaissance geologic map of Chichagof Island and northwestern Baranof Island, Alaska: U. S. Geol. Survey Misc. Geol. Inv. Map I-338

Mackevett, E. M., Jr., 185\%, Reconnaissance for uranium in Alaska, in Geologic Investigations of radioactive deposits: U. S. Geol. Survey Tech. Inf. Service Extension Pub. TEl-700, 287 p.

- 1983, Geology and ore deposits of the Bokan Mountain uranium-thortum area, southeastern Alaska: U. S. Geol. Survey Bull, 1154, 118 p.

MacKevett, E. M., Jr.; Blake, M. C., Jr., 1904, Geology of the Sumdum copper-zinc prospect, southeastern Alaska: U. S. Geol. Survey Bull. 1108-E, 31 p.

MacKevett, E. M., Jr.; Brew, D. A.; Hawley, C. C.; Huff, L. C.; Smith, J. G., 1987, Mineral Resources of Glacier Bay National Monument, Alaska: U. S. Geol. Survey open-file rept. 280,178 p.

Matzko, J. J.; Freeman, V. L., 1983, Summary of reconnaissance for uranium in Alaska, in Contributions to economic geology of Alaska: U. S. Geol, Survey Bull. 1155, p. $33-49$

Mertic, J. B., Jr., 1921, Lode mining in the Juneau and Ketchikan districts: U] S. Geol. Survey Bull. 714-b, p. $109-112$

Muffler, L. J. P., 1967, Stratigraphy of the Keku Islets and neighboring parts of Kutu and Kupreanof Islands, southeastem Alaska: U. S. Geol. Survey Bull. $1241-\mathrm{C}, 51 \mathrm{p}$.

Race, W. H., 1982, Preliminary geochemica! investigations, Tracy and Endicott Arm area: Alaska Div. Mines and Minerals Mineral Inv. 115-3, 11 p.

Race, W. H, Rose, A. W., 1087, Geochemical and geological investigations of Admiralty lsland, Alaska: Alaska Div. Mines and Minerals Gcochem. Rept. No. 8,43 p.

Roehm, J, C., 1942, Alaska Territorial Department of Mines: 1. R. for 1942, 18 p.

- 1945. Alaska Territorial Department of Mines: I. R. for June, $1945,13 \mathrm{p}$.

Sainsbury. C.L., 1957, Some pegmatite deposits in Southeastern Alaska: U.S. Geol. Bull. 1024-G, p. iv, 141181.

Schubert, A. E., 1971, Uranium requirements for light water reactors: Mining Cong. Jour, Vol. 57, No. 2, Feb., p. 101-103

Smith, P. S., 1939, Aerial geology of Alaska: U. S. Geol. Survey Prof. Paper 192, p. 58-59

Stevenson, J. S., 1951, Uranium Mineralization in British Columbia: Econ. Geol. V 48, No. 4, p. 353388

Twenhofel, W. S.; Reed, J. E.; Gates, G. O., 1949, Some mineral investigations in southeastern Alaska: U. S. Geol. Survey Bull. 9a3-A, p. 28-30 
Twenhofel, W. S; Robinson, G. D.; Gault, H. R., 1946, Molybdenite investigations in southeastern Alaska: U. S. Geol. Survey Bull. 947-8, 38 p.

Wedow, Helmuth, Jr.; White, M. G.; Moxharn, R. M., 1051, Interim report on an appraisal of the uranium possibilities of Alaska: U. S. Geol. Survey Trace Elements Mern, Rept. 235, 124 p.

Wedow, Helmuth, Jr; others, 1953, Preliminary summary of reconnaissance for uranium and thorium in Alaska, 1952; U. S. Geol. Survey Circ. 248, 15 p.

West, W. S.; Benson, P. D., 1955, Investigations for radioactive deposits in southeastern Alaska; U. S. Geol. Survey Bull. 1024-B, 54 p.

White, M. G.; West, W. S.; Tolbert, G. E.; Nelson, A. E: Houston, J. R., 1952, Preliminary summary of reconnaissance for uranium in Alaska, 1951: $U$. S. Geal. Survey Circ. 196, 18 p.

Williams, J. A., 1952a, Mountain View property, Hyder district: Alaska Ter. Dept. Mines Property Exam. 120-11, $8 \mathrm{p}$.
- 1952b, Salmon Bay area: Alaska Terr. Dept. Mines Itinerary Rept. Sept. 2B, 2 p.

- 1955a, BBH property, Sumdum quadrange, radioactives: Alaska Terr. Dept. Mines Property Exam. $125-7,3 \mathrm{p}$

- 1955b, Carrol Ann property (Brokan Mountain area): Alaska Terr. Dept. Mines Property Exam. 12l-7, $4 \mathrm{p}$.

- 1955c, I and L property (Bokan Mountain): Alaska Terr. Dept. Mines Property Exam. 12l-5, 5 p.

- 1955d, Lazo property (Moira Sound): Alaska Terr. Dept. Mines Property Exam. 121-6, 3 p.

- 1950, Black Jack No. 7 Claim, Ketchikan guadrangle, radioactives: Alaska Tert. Dept. Mines Property Exam. 120-14, 3 p.

Wrigbt, C. W, 1908, A reconnaissance of Admiralty Island, Alaska: U. S. Geol. Survey Bull. 287, 155 p.

Wright, F. E.: Wright, C. W., 1908. The Ketchikan and Wrangell mining districts, Alaska: U. S. C.eol. Survey Bull. 347, 303 p. 